\title{
Representation of the Community Earth System Model (CESM1) CAM4-chem within the Chemistry-Climate Model Initiative (CCMI)
}

\author{
Simone Tilmes $^{1}$, Jean-Francois Lamarque ${ }^{1}$, Louisa K. Emmons ${ }^{1}$, Doug E. Kinnison ${ }^{1}$, Dan Marsh ${ }^{1}$, \\ Rolando R. Garcia ${ }^{1}$, Anne K. Smith ${ }^{1}$, Ryan R. Neely ${ }^{1}$, Andrew Conley ${ }^{1}$, Francis Vitt ${ }^{1}$, Maria Val Martin ${ }^{2}$, \\ Hiroshi Tanimoto ${ }^{3}$, Isobel Simpson ${ }^{4}$, Don R. Blake ${ }^{4}$, and Nicola Blake ${ }^{4}$ \\ ${ }^{1}$ National Center for Atmospheric Research, Boulder, CO, USA \\ ${ }^{2}$ The University of Sheffield, Sheffield, S1 3JD, UK \\ ${ }^{3}$ National Institute for Environmental Studies, Tsukuba, Ibaraki 305-8506, Japan \\ ${ }^{4}$ University of California, Irvine, CA, USA \\ Correspondence to: Simone Tilmes (tilmes@ucar.edu)
}

Received: 23 October 2015 - Published in Geosci. Model Dev. Discuss.: 18 January 2016

Revised: 8 April 2016 - Accepted: 21 April 2016 - Published: 20 May 2016

\begin{abstract}
The Community Earth System Model (CESM1) CAM4-chem has been used to perform the Chemistry Climate Model Initiative (CCMI) reference and sensitivity simulations. In this model, the Community Atmospheric Model version 4 (CAM4) is fully coupled to tropospheric and stratospheric chemistry. Details and specifics of each configuration, including new developments and improvements are described. CESM1 CAM4-chem is a low-top model that reaches up to approximately $40 \mathrm{~km}$ and uses a horizontal resolution of $1.9^{\circ}$ latitude and $2.5^{\circ}$ longitude. For the specified dynamics experiments, the model is nudged to ModernEra Retrospective Analysis for Research and Applications (MERRA) reanalysis. We summarize the performance of the three reference simulations suggested by CCMI, with a focus on the last 15 years of the simulation when most observations are available. Comparisons with selected data sets are employed to demonstrate the general performance of the model. We highlight new data sets that are suited for multimodel evaluation studies. Most important improvements of the model are the treatment of stratospheric aerosols and the corresponding adjustments for radiation and optics, the updated chemistry scheme including improved polar chemistry and stratospheric dynamics and improved dry deposition rates. These updates lead to a very good representation of tropospheric ozone within $20 \%$ of values from available observations for most regions. In particular, the trend and magnitude of surface ozone is much improved com-
\end{abstract}

pared to earlier versions of the model. Furthermore, stratospheric column ozone of the Southern Hemisphere in winter and spring is reasonably well represented. All experiments still underestimate CO most significantly in Northern Hemisphere spring and show a significant underestimation of hydrocarbons based on surface observations.

\section{Introduction}

The Chemistry Climate Model Initiative (CCMI) coordinates evaluation and modeling activities for both tropospheric and stratospheric global chemistry-climate models. The CCMI-1 model experiments include three reference and several sensitivity experiments to evaluate the performance of chemistry-climate models in the troposphere and stratosphere for past and present conditions between 1960 and 2010 (REFC1 and REFC1SD), and to identify future climate trends between 1960 and 2100 (REFC2) (Eyring et al., 2013). The REFC1SD simulation differs from the REFC1 simulation in that the dynamics are specified from reanalysis. Comprehensive tropospheric and stratospheric chemistry has been integrated into the Community Atmospheric Model version 4 (CAM4-chem) of the Community Earth System Model (CESM1) and shows a reasonable representation of present-day atmospheric composition in the troposphere (Lamarque et al., 2012; Tilmes et al., 2015) and stratosphere 
(Lamarque et al., 2010). This model is therefore well suited to participate in the CCMI model intercomparison project.

The purpose of this paper is to summarize the CESM1 CAM4-chem model configurations that were used to perform the reference CCMI model experiments (Sect. 2) including physics, dynamics, the chemical mechanism and aerosol description, as well as a summary of newly integrated diagnostics. We also describe issues that have been identified after the simulations were performed and their likely impacts. In addition, we summarize the global performance of the model in Sect. 3, and evaluate selected diagnostics based on observational data sets in Sect. 4. We employ existing and new data sets to evaluate the general performance of the model. More in-depth analysis and evaluations will follow in multi-model comparison studies. Improvements in comparison to earlier versions of the model are discussed in the Conclusions.

\section{Model description}

CESM is a fully coupled Earth System model, which includes atmosphere, land, ocean and sea-ice components. All CCMI simulations are carried out with the same model code that is based on CESM version 1.1.1 (CESM1) (Neale et al., 2013), with modifications discussed below. The configuration of the model used here fully couples the Community Atmosphere Model version 4 (CAM4), the Community Land model version 4.0 (CLM4.0), the Parallel Ocean Program version 2 (POP2) and the Los Alamos sea ice model (CICE version 4). The land model was run without an interactive carbon or nitrogen cycle and only the atmospheric and land components are coupled to the chemistry. The climatological present-day land cover is used for all simulations.

\subsection{The atmosphere model}

Detailed information about the physics of the atmosphere model used here are described in Neale et al. (2013) and Richter and Rasch (2008), and also summarized in Lamarque et al. (2012, and references therein). In summary, deep convection is treated by Zhang and McFarlanle (1995) with improvements in the convective momentum transport (Richter and Rasch, 2008), which improved surface winds, stresses and tropical convection. At the same time, an entraining plume was added to the convection parameterization, which together with the momentum transport improved the representation of El Niño-Southern Oscillation (ENSO) significantly (Neale et al., 2008). The photolysis calculation uses a look-up table between 200 and $750 \mathrm{~nm}$ and online calculations for wavelengths $<200 \mathrm{~nm}$. Only changes in the ozone column, but not in the aerosol burden, impact photolysis rates. Attenuation of the spectral irradiance above the model top is calculated using the approach of Kinnison et al. (2007) and Lamarque et al. (2012).
Processes in the planetary boundary layer are represented using the Holtslag and Boville (1993) parameterization. Wet deposition of gas and aerosol compounds is based on Neu and Prather (2012), as described in Lamarque et al. (2012). In this version of CAM4-chem all aerosols in the cloudy fraction of the grid cell are assumed to reside within cloud droplets and are removed in proportion to the cloud water removal rate. Aerosols directly impact the radiation and chemistry, but do not change the radiative properties of clouds (i.e., no representation of the aerosol indirect effects is included).

Lightning $\mathrm{NO}_{x}$ is parameterized following Price and Vaughan (1993) and Price et al. (1997). The global amount of produced lightning $\mathrm{NO}_{x}$ is scaled differently for the specified dynamics (SD) and the free-running (FR) experiments due to differences in the meteorology to ensure values of approximately $3-5 \mathrm{Tg} \mathrm{N}_{\text {year }}{ }^{-1}$ for present-day conditions.

\subsubsection{Model grid}

For all CCMI reference simulations, CESM1 CAM4-chem uses a horizontal grid with a resolution of $1.9^{\circ} \times 2.5^{\circ}$ (latitude by longitude), and uses the finite volume dynamical core. The top of the model is located at $3 \mathrm{hPa}$ (about $40 \mathrm{~km}$ ). The vertical coordinate is sigma (hybrid terrainfollowing pressure) in the troposphere, switching over to isobaric at pressure levels less than $100 \mathrm{hPa}$; the vertical resolution of the model depends on the configuration of the experiment. The atmosphere model, CAM4, makes use of two different configurations, the FR (with 26 vertical levels) and the $\mathrm{SD}$ (with 56 vertical levels adopted from the analysis fields); see Lamarque et al. (2012). For the SD configuration, internally derived meteorological fields are nudged every time step of $30 \mathrm{~min}$ by $1 \%$ towards reanalysis fields (equivalent to a $50 \mathrm{~h}$ Newtonian relaxation timescale for nudging) from Modern-Era Retrospective Analysis for Research and Applications (MERRA) reanalysis (http://gmao. gsfc.nasa.gov/merra/) (Rienecker et al., 2011). Nudged meteorological fields include wind components, temperatures, surface pressure, surface stress, latent and sensible heat flux. The MERRA reanalysis fields are interpolated to the horizontal resolution of the model prior to running the simulation. The MERRA surface geopotential height is used for the SD simulations to be consistent with the reanalysis fields.

\subsubsection{Quasi-Biennial Oscillation}

The SD configuration of the model incorporates the observed quasi-biennial oscillation (QBO), which is present in the meteorological analysis fields. The limited vertical resolution of the FR model configurations does not allow for the generation of an internal QBO in CAM4-chem. Therefore, for the FR CCMI experiments, REFC1 and REFC2, the QBO is imposed in the model by relaxing equatorial zonal winds between 90 to $3 \mathrm{hPa}$ to the observed interannual variability, following the approach by Matthes et al. (2010). Here, we 
vary the QBO phase between eastward and westward phase using an approximate 28-month period, similar to what was done by Marsh et al. (2013).

\subsubsection{Improved gravity wave representation}

The representation of sub-grid-scale gravity waves (GW) in CAM was formerly limited to orographic gravity waves using the parameterization adapted from McFarlane (1987). In the present simulations, the parameterizations of nonorographic gravity waves generated by convection (Beres et al., 2005) and fronts (Richter et al., 2010), which were developed for the Whole Atmosphere Community Climate Model (WACCM), are also included.

In addition, we have added another gravity wave module to represent the waves with large horizontal wavelengths that are often observed in the stratosphere (e.g., Zink and Vincent, 2001). The new GW module is adopted from the inertia-gravity wave (IGW) parameterization developed by Xue et al. (2012) for an interactive QBO. The formulation includes the impact of the Coriolis force on gravity wave propagation and breaking. Rather than applying it in the equatorial region, as done by Xue et al. (2012), we use a more general mechanism for determining sources; gravity waves are triggered by the same frontal threshold used for the mesoscale gravity waves (Richter et al., 2010). This has the impact of shifting the bulk of the waves from the tropics to middle and high latitudes. In the current implementation, gravity waves have a narrow phase speed spectrum $(-20$ to $20 \mathrm{~m} \mathrm{~s}^{-1}$ ) and long horizontal wavelength $(1000 \mathrm{~km})$. The momentum forcing associated with this module particularly impacts the winter stratosphere. In the Southern Hemisphere (SH), it enhances downwelling and increases the winter stratospheric temperature, which in previous simulations was substantially colder than observed.

However, it was found, that the version of the IGW parameterization used for the performed experiments has a narrow IGW spectrum centered on zero phase velocity instead of being centered on the speed of the background wind at the GW launch level, as in the standard GW parameterization. Even with this shortcoming, the model produces a much improved temperature evolution in the stratosphere, in particular in the SH high latitudes compared to earlier versions. This results in a well-resolved ozone hole in winter and spring over Antarctica. No significant changes are expected from a corrected IGW parameterization for the troposphere.

\subsubsection{Tropospheric aerosols}

CAM4-chem runs with the bulk aerosol model (BAM), which simulates the distribution of externally mixed sulfate, black carbon (BC), primary organic carbon (OC), sea-salt and dust, as described in Lamarque et al. (2012). The dust emissions are calibrated so that the global dust aerosol optical depth (AOD) is about 0.025 to 0.030 (Mahowald et al.,
2006). The distribution of sea-salt and dust are described using four size bins. In CAM4-chem, the formation of secondary organic aerosols (SOA) is coupled to the chemistry and biogenic emissions. SOA are derived using the twoproduct model approach using laboratory determined yields for SOA formation from monoterpene, isoprene and aromatic photooxidation, as described in Heald et al. (2008). The aging process of $\mathrm{BC}$ and $\mathrm{OC}$ from hydrophobic to hydrophilic is included through a specified conversion timescale. For all aerosol species, the size distributions are specified as in Lamarque et al. (2012). Aerosols interact with the gas-phase chemistry through heterogeneous reactions that depend on the available surface area density (SAD), as discussed below. For the tropospheric SAD calculation, sulfate, hydrophilic black carbon, primary organic carbon and nitrates are included, where SOA has not been included. This may lead to a significant underestimation of tropospheric SAD in the experiments.

\subsubsection{Representation of aerosols in the stratosphere}

Aerosol mass, heating rates and SAD are revised in this version compared to earlier configurations. Most significantly, the model uses a new stratospheric aerosol and SAD data set, derived based on observations, to force models participating in CCMI (Eyring et al., 2013). In addition, in order to fully utilize the aerosol size information provided by the new model input file, the optics in the radiative transfer code associated with CAM4 (i.e., CAMRT) (Neale et al., 2010) have been modified to include a lookup table for aerosol effective radius in the shortwave radiation scheme. The new description leads to an updated representation of volcanic heating for REFC1 and REFC2, whereas in REFC1SD volcanic heating is included through the nudged temperature fields. See Neely et al. (2015) for a full description of changes to the stratospheric aerosol scheme. Tropospheric aerosols that enter the stratosphere are promptly removed (as listed in Table A2) since the aerosol burden in the stratosphere is prescribed.

\subsubsection{Coupling to the land model}

Dry deposition velocity for tracers in the atmosphere are calculated online in CLM4.0. An updated calculation is used, where leaf and stomatal resistances are coupled to the leaf area index (LAI) and are also linked to the photosynthesis provided by the land model, as described in Val Martin et al. (2014).

Biogenic emissions are calculated online in CLM using the Model of Emissions of Gases and Aerosols from Nature (MEGAN), version 2.1 (Guenther et al., 2012). An erroneous implementation of MEGAN in this version differs from the description of Guenther et al. (2012) by using the LAI from the previous model time step $(30 \mathrm{~min})$ instead of the average of the previous 10 days. In addition, in this version we are using a fixed $\mathrm{CO}_{2}$ mixing ratio, instead of the simulated 
atmospheric value, in the calculation of the $\mathrm{CO}_{2}$ inhibition effect on isoprene emissions. The corrected implementation is closer to the algorithm of Guenther et al. (2012).

\subsection{Chemical mechanism}

The chemical mechanism of CAM4-chem includes 169 species, listed in Table A1 in the Appendix. Depending on the chemical lifetime of each species, an explicit or semi-implicit solver is used. Emissions of gas-phase and aerosol species, as indicated in Table A1, are in general distributed at the surface. Only aircraft emissions of BC and nitrogen dioxide, and volcanic emissions of sulfur and sulfate, are vertically distributed. Species with lower boundary conditions, as indicated in Table A1, as discussed in Sect. 2.3.2. Different species experience wet and/or dry deposition, as also listed in Table A1. Furthermore, 14 artificial tracers are implemented as recommended by CCMI (Eyring et al., 2013, Sect. 4.2.1): $\mathrm{NH}_{5}, \mathrm{NH}_{50}, \mathrm{NH}_{50 \mathrm{~W}}$, $\mathrm{AOA}_{\mathrm{NH}}, \mathrm{ST} 80_{25}, \mathrm{CO}_{25}, \mathrm{CO}_{50}, \mathrm{SO}_{2 \mathrm{t}}, \mathrm{SF} 6 \mathrm{em}, \mathrm{O}_{3} \mathrm{~S}, \mathrm{E} 90$, E90 $0_{\mathrm{NH}}, \mathrm{E} 90_{\mathrm{SH}} \cdot \mathrm{O}_{3} \mathrm{~S}$ is a stratospheric ozone tracer that represents the amount of ozone in the troposphere with its source in the stratosphere. $\mathrm{O}_{3} \mathrm{~S}$ is set to stratospheric values at the tropopause, and experiences the same loss rates as ozone in the troposphere, as defined by CCMI. As interpreted from the CCMI recommendation, dry deposition is not included, which will lead to an overestimation of $\mathrm{O}_{3} \mathrm{~S}$ in the lower boundary layer when compared to ozone (which is dry deposited).

The chemical mechanism, is based on the Model for Ozone and Related chemical Tracers (MOZART), version 4 mechanism for the troposphere (Emmons et al., 2010). It further includes extended stratospheric chemistry (Kinnison et al., 2007) and updates, as described in Lamarque et al. (2012) and Tilmes et al. (2015). The reactions include photolysis, gas-phase chemistry and heterogeneous chemistry, in both troposphere and stratosphere. The complete chemical mechanism is listed in Table A2 and incorporates all the latest updates. All aerosols and some gas-phase species, including $\mathrm{H}_{2} \mathrm{O}, \mathrm{O}_{2}, \mathrm{CO}_{2}, \mathrm{O}_{3}, \mathrm{~N}_{2} \mathrm{O}, \mathrm{CH}_{4}, \mathrm{CFC} 11, \mathrm{CFC} 12$, are radiatively active.

Reaction rates are updated following JPL2010 recommendations (Sander et al., 2011). Bromoform $\left(\mathrm{CHBr}_{3}\right)$ and dibromomethane $\left(\mathrm{CH}_{2} \mathrm{Br}_{2}\right)$ were added to the model to represent the stratospheric bromine loading from very short-lived (VSL) species. The surface volume mixing ratio for these two VSL species was set globally to $1.2 \mathrm{ppt}$ (i.e., $6 \mathrm{ppt}$ total bromine). This approach adds an additional $\approx 5$ ppt of inorganic bromine to the stratosphere. The resulting stratospheric total inorganic bromine abundance (for present-day conditions) from both long-lived and VSL species is $\approx 21.5 \mathrm{ppt}$. Besides the current lower boundary condition (LBC) approach for VSL species, CAM4-chem can be also configured with a full-VSL mechanism, including detailed gasphase halogen chemistry mechanism, geographically and time-dependent distributed sources of nine halocarbons and improved representation of heterogeneous recycling and removal rates in the troposphere (Fernandez et al., 2014; SaizLopez et al., 2014).

Details on updated reactions and processes for chemistry in the polar stratosphere are described in Wegner et al. (2013) and Solomon et al. (2015).

Diagnostics of the tropospheric ozone production and loss rates are explicitly calculated; see Table $\mathrm{A} 3$, in adding the listed reaction rates $r$ of two species $A$ and $B, r(A-B)$, as well as the photolysis reaction of ONITR (defined as lumped organic nitrate species that includes nitrates derived from the $\mathrm{OH}-$ and $\mathrm{NO}_{3}$-initiated oxidation of isoprene and terpenes, and related species), called jonitr:

$$
\begin{aligned}
\text { O3-Prod } & =r(\mathrm{NO}-\mathrm{HO} 2)+r(\mathrm{CH} 3 \mathrm{O} 2-\mathrm{NO}) \\
& +r(\mathrm{PO} 2-\mathrm{NO})+r(\mathrm{CH} 3 \mathrm{CO} 3-\mathrm{NO}) \\
& +r(\mathrm{C} 2 \mathrm{H} 5 \mathrm{O} 2-\mathrm{NO})+0.92 \cdot r(\mathrm{ISOPO} 2-\mathrm{NO}) \\
& +\mathrm{r}(\mathrm{MACRO} 2-\mathrm{NO})+r(\mathrm{MCO} 3-\mathrm{NO}) \\
& +r(\mathrm{C} 3 \mathrm{H} 7 \mathrm{O} 2-\mathrm{NO})+r(\mathrm{RO} 2-\mathrm{NO}) \\
& +r(\mathrm{XO} 2-\mathrm{NO})+0.9 \cdot r(\mathrm{TOLO} 2-\mathrm{NO}) \\
& +r(\mathrm{TERPO} 2-\mathrm{NO})+0.9 \cdot r(\mathrm{ALKO} 2-\mathrm{NO}) \\
& +r(\mathrm{ENEO} 2-\mathrm{NO})+r(\mathrm{EO} 2-\mathrm{NO}) \\
& +r(\mathrm{MEKO} 2-\mathrm{NO})+0.4 \cdot r(\mathrm{ONITR}-\mathrm{OH}) \\
& +\mathrm{j} \text { initr } \\
& +r(\mathrm{O} 1 \mathrm{D}-\mathrm{H} 2 \mathrm{O})+r(\mathrm{OH}-\mathrm{O} 3) \\
& +r(\mathrm{HO} 2-\mathrm{O} 3)+r(\mathrm{C} 3 \mathrm{H} 6-\mathrm{O} 3) \\
& +0.9 \cdot r(\mathrm{ISOP}-\mathrm{O} 3)+r(\mathrm{C} 2 \mathrm{H} 4-\mathrm{O} 3) \\
& +0.8 \cdot r(\mathrm{MVK}-\mathrm{O} 3)+0.8 \cdot r(\mathrm{MACR}-\mathrm{O} 3) \\
& +r(\mathrm{C} 10 \mathrm{H} 16-\mathrm{O} 3)
\end{aligned}
$$

These are defined based on the rate-limiting terms for the gas-phase reactions of the $\mathrm{O}_{x}$ family $\left(\mathrm{O}_{3}, \mathrm{O}, \mathrm{O}_{1} \mathrm{D}, \mathrm{NO}_{2}\right)$, not including $\mathrm{O}_{2}+h v \rightarrow 2 \mathrm{O}$ production, $\mathrm{O}_{x}, \mathrm{ClO}_{x}$, and $\mathrm{BrO}_{x}$ losses, and are therefore not valid for the stratosphere. The sum of those rates are very similar to the explicit calculation of the net chemical change of ozone (as listed in Table A2).

\subsection{Experimental Setup}

The reference experiments are set up according to the CCMI recommendation, including surface and altitude-dependent emissions, and lower boundary conditions. The three reference experiments are performed with the recommended emissions. REFC1 and REFC1SD (years 1960-2010) use the same emissions, excluding biogenic emissions. Anthropogenic and biomass burning emissions are from the Monitoring Atmospheric Composition and Climate/CityZen inventory (MAC City) emission data set and change every year (Granier et al., 2011). For REFC2 (years 1960-2100), anthropogenic and biomass burning emissions are taken from AR5 (Eyring et al., 2013) (see Fig. A1), which only vary ev- 
ery 5-10 years. All emissions include a seasonal cycle. Biogenic emissions are calculated every time step by MEGAN, as described in Sect. 2.1.6.

The REFC1SD experiment is nudged to analyzed air temperatures, winds, surface fluxes and surface pressure, and uses the Hadley Centre Global Sea Ice and Sea Surface Temperature version 2 (HadISST2) observed time-dependent data set for sea surface temperatures (SSTs) and sea ice. The REFC1 experiment also uses prescribed SSTs and sea ice, while the REFC2 simulation calculates temperatures in the ocean and atmosphere. We have carried out one simulation for REFC1SD, and an ensemble of three members for each REFC1 and REFC2.

The solar cycle is prescribed using observed daily fields for the years until 2010. For the future period in REFC2, we follow the CCMI recommendation and repeat a sequence of the last four solar cycles (20-23), as defined in http: //solarisheppa.geomar.de/ccmi.

\subsubsection{Initial conditions and spin-up}

CAM4-chem initial conditions for the three REFC1 and REFC2 ensemble members are taken from 3 realizations of CESM1-WACCM 20th Century ensemble for CMIP5 (Marsh et al., 2013). The spin-up period started in 1950 and ran through 1959. The experiments simulated the years 1960 to 2010 (REFC1) and 1960 to 2100 (REFC2). Initial conditions for the REFC1SD simulation are taken from the first REFC1 ensemble member in 1975. The spin-up of this experiment covered the years 1975 to 1979 , repeating 1979 meteorological analysis for each year. The experiment was performed between 1980 and 2010.

\subsubsection{Lower boundary conditions}

For all of the three reference experiments the same monthly and annually varying lower boundary conditions are used based on the Representation Concentration Pathway 6.0 (RCP6.0) Coupled Model Intercomparison Project Phase 5 (CMIP5) future projection (Taylor et al., 2012). We prescribe $\mathrm{CO}_{2}, \mathrm{~N}_{2} \mathrm{O}, \mathrm{CH}_{4}$, as well as the following halogen species based on the CCMI recommendations: $\mathrm{CCl}_{4}, \mathrm{CF}_{2} \mathrm{ClBr}$, $\mathrm{CF}_{3} \mathrm{Br}, \mathrm{CFC} 11$, CFC113, CFC12, $\mathrm{CH}_{3} \mathrm{Br}, \mathrm{CH}_{3} \mathrm{CCl}_{3}, \mathrm{CH}_{3} \mathrm{Cl}$, $\mathrm{H}_{2}$, HCFC22, CFC114, CFC115, HCFC141b, HCFC142b, $\mathrm{CH}_{2} \mathrm{Br}_{2}, \mathrm{CHBr}_{3}, \mathrm{H} 1202, \mathrm{H} 2402, \mathrm{SF}_{6}$. A north-south gradient was added for $\mathrm{CH}_{3} \mathrm{Br}$, $\mathrm{HCFC} 22$, HCFC141b, HCFC142b, based on the HIAPER (High-Performance Instrumented Airborne Platform for Environmental Research) Pole-to-Pole Observations (HIPPO) (Wofsy et al., 2011; Mijeong Park, personal communication, 2015).

\section{Model performance}

\subsection{Global diagnostics}

The general state of the model is investigated by comparing diagnostics of globally averaged values between different model experiments that are averaged between 1995 and 2010 (Table 1). The global surface temperatures (TS) of all three experiments are in agreement within $0.15 \mathrm{~K}$ for the observed period (Table 1). REFC1SD land temperature (TS land) is on average $0.25 \mathrm{~K}$ higher than for REFC 1 and $0.15 \mathrm{~K}$ higher than for the REFC2 experiments (Table 1). The largest deviations occur over high latitudes (not shown). In the REFC1SD experiment, low cloud fraction is significantly larger than in the other experiments, which results in a much smaller shortwave cloud forcing (SWCF) of $-83 \mathrm{~W} \mathrm{~m}^{-2}$ compared the other experiments that are with $54-56 \mathrm{~W} \mathrm{~m}^{-2}$ more in line with observations.

Differences in clouds and land surface temperatures between the reference experiments result in different biogenic emissions of volatile organic components (VOCs) (Fig. 1). REFC1SD biogenic emissions are about $10 \%$ lower than in the REFC1 experiment and about $15 \%$ lower than in the REFC2 experiment. The emissions differ the most in summer during their peak (Fig. 1, bottom row). Despite the fact that surface temperatures in REFC1SD are warmer than in REFC1, more low cloud clouds and reduced solar radiation (as evident in photolysis rates) near the surface may be the important driver for the reduced biogenic emissions in REFC1SD, which has to be further investigated. Other differences in the REFC1 and REFC2 VOC emissions arise from different anthropogenic and biomass burning emissions, while biogenic emissions differ by less than $10 \%$ (Table 1). Despite the variation in the reference experiments, biogenic emissions are in agreement with earlier estimates (e.g., Young et al., 2013).

The performance of the model in simulating tropospheric chemical variables (Table 1) is similar to earlier studies (e.g., Tilmes et al., 2015). Methane lifetime is low compared to observational estimates of 11.2 years (Prather et al., 2012). Ozone budgets, including ozone burden, stratospheretroposphere exchange, and budgets of carbon monoxide $(\mathrm{CO})$, are in agreement with earlier model studies (Young et al., 2013). Aerosol burdens of primary organic matter $(\mathrm{POM})$ and SOA are low, but within the spread of other model results (Tsigaridis et al., 2014). The $\mathrm{SO}_{4}$ burden with 0.45 to $0.51 \mathrm{TgS}$ and the lifetime of 3.0 to 3.5 days is somewhat low compared to the Aerocom multi-model mean of $0.66 \mathrm{TgS}$ and 4.12 days, respectively (e.g., Liu et al., 2012). The dust optical depth around 0.04 is somewhat higher than suggested by Mahowald et al. (2006). 
Table 1. Overview of global diagnostics for different experiments, averaged between 1995 and 2010. Lifetimes and burdens are calculated for the troposphere defined for regions where ozone is below $150 \mathrm{ppb}$.

\begin{tabular}{|c|c|c|c|c|c|c|c|}
\hline CESM1 CAM4chem & REFC1SD & REFC1.1 & REFC1.2 & REFC1.3 & REFC 2.1 & REFC 2.2 & REFC 2.3 \\
\hline Meteorology & MERRA & CAM4 & CAM4 & CAM4 & CAM4 & CAM4 & CAM4 \\
\hline Vert. Res. & $56 \mathrm{~L}$ & $26 \mathrm{~L}$ & $26 \mathrm{~L}$ & $26 \mathrm{~L}$ & $26 \mathrm{~L}$ & $26 \mathrm{~L}$ & $26 \mathrm{~L}$ \\
\hline TS Global & 288.43 & 288.27 & 288.27 & 288.28 & 288.35 & 288.40 & 288.41 \\
\hline TS Land & 282.37 & 282.10 & 282.12 & 282.17 & 282.23 & 282.20 & 282.23 \\
\hline SWCF & -82.47 & -55.96 & -56.01 & -55.97 & -54.66 & -54.65 & -54.78 \\
\hline $\mathrm{CH}_{4}$ Burden $(\mathrm{Tg})$ & 3991.3 & 4100.5 & 4103.8 & 4099.3 & 4101.4 & 4105.0 & 4103.1 \\
\hline $\mathrm{CH}_{4}$ Lifet. (year) & 7.6 & 8.0 & 8.1 & 8.1 & 8.2 & 8.2 & 8.2 \\
\hline $\mathrm{CH}_{3} \mathrm{CCl}_{3}$ Lifet. (year) & 4.5 & 4.8 & 4.8 & 4.8 & 4.9 & 4.9 & 4.9 \\
\hline CO Burden (Tg) & 289.6 & 303.6 & 305.3 & 305.7 & 315.4 & 316.7 & 315.3 \\
\hline CO Emis. (Tg year ${ }^{-1}$ ) & 1114.8 & 1119.3 & 1126.5 & 1126.8 & 1170.1 & 1171.1 & 1169.9 \\
\hline CO Dep. $\left(\right.$ Tg year $\left.^{-1}\right)$ & 125.8 & 120.7 & 122.0 & 122.1 & 122.7 & 123.0 & 122.9 \\
\hline CO Chem. Loss $\left(\operatorname{Tg}_{\text {year }}{ }^{-1}\right)$ & 2264.1 & 2294.2 & 2295.3 & 2298.0 & 2348.4 & 2353.3 & 2345.5 \\
\hline CO Lifet. (days) & 44.2 & 45.9 & 46.1 & 46.1 & 46.6 & 46.7 & 46.6 \\
\hline $\mathrm{O}_{3}$ Burden $(\mathrm{Tg})$ & 332.5 & 326.9 & 326.5 & 326.4 & 327.8 & 327.2 & 327.0 \\
\hline $\mathrm{O}_{3}$ Dep. $\left(\right.$ Tg year $\left.^{-1}\right)$ & 871.7 & 894.4 & 893.9 & 894.2 & 895.0 & 892.8 & 894.7 \\
\hline $\mathrm{O}_{3}$ Chem. Loss $\left(\right.$ Tg year $\left.^{-1}\right)$ & 4256.0 & 4268.3 & 4250.6 & 4259.0 & 4287.6 & 4293.5 & 4278.9 \\
\hline $\mathrm{O}_{3}$ Chem. Prod. $\left(\right.$ Tg year $\left.^{-1}\right)$ & 4693.8 & 4710.0 & 4706.5 & 4708.3 & 4747.2 & 4756.9 & 4744.1 \\
\hline $\mathrm{O}_{3}$ Net Chem.Change $\left(\mathrm{Tg}_{\text {year }}{ }^{-1}\right)$ & 392.9 & 420.9 & 430.5 & 426.0 & 432.5 & 436.5 & 438.2 \\
\hline $\mathrm{O}_{3}$ STE $\left(\right.$ Tg year $\left.^{-1}\right)$ & 478.8 & 473.4 & 463.4 & 468.2 & 462.5 & 456.4 & 456.5 \\
\hline Isop. Emis. $\left(\right.$ Tg year $\left.^{-1}\right)$ & 454.2 & 512.6 & 511.8 & 515.0 & 546.6 & 551.6 & 545.6 \\
\hline Monoterp. Emis. $\left(\right.$ Tg year $^{-1}$ ) & 138.9 & 150.0 & 150.0 & 150.3 & 155.4 & 156.4 & 155.0 \\
\hline Methanol Emis. (Tg year ${ }^{-1}$ ) & 100.4 & 114.6 & 114.8 & 114.9 & 113.7 & 114.9 & 113.4 \\
\hline Aceton Emis. (Tg year $\left.{ }^{-1}\right)$ & 41.6 & 44.3 & 44.3 & 44.3 & 47.8 & 48.1 & 47.7 \\
\hline Lightning Prod. (TgN year ${ }^{-1}$ ) & 4.5 & 4.8 & 4.7 & 4.8 & 4.7 & 4.7 & 4.7 \\
\hline Total optical depth & 0.107 & 0.119 & 0.119 & 0.119 & 0.118 & 0.118 & 0.118 \\
\hline Dust optical depth & 0.041 & 0.043 & 0.043 & 0.043 & 0.040 & 0.041 & 0.040 \\
\hline POM Burden (TgC) & 0.75 & 0.73 & 0.73 & 0.74 & 0.77 & 0.77 & 0.77 \\
\hline POM Emis. (TgC year ${ }^{-1}$ ) & 48.38 & 47.99 & 48.38 & 48.38 & 51.23 & 51.23 & 51.23 \\
\hline POM Lifet. (days) & 7.23 & 7.18 & 7.15 & 7.19 & 7.05 & 7.06 & 7.01 \\
\hline SOA Burden $(\mathrm{TgC})$ & 0.54 & 0.49 & 0.49 & 0.49 & 0.51 & 0.51 & 0.50 \\
\hline SOA Chem. Prod. $\left(\mathrm{TgC}_{\text {year }}{ }^{-1}\right)$ & 32.79 & 34.45 & 34.43 & 34.79 & 35.86 & 36.32 & 35.54 \\
\hline SOA Lifet. (days) & 0.54 & 0.49 & 0.49 & 0.49 & 0.51 & 0.51 & 0.50 \\
\hline BC Burden ( $\mathrm{TgC})$ & 0.12 & 0.12 & 0.12 & 0.12 & 0.12 & 0.12 & 0.12 \\
\hline BC Emis. (TgC year $\left.{ }^{-1}\right)$ & 7.71 & 7.68 & 7.71 & 7.71 & 7.95 & 7.95 & 7.95 \\
\hline BC Lifet. (days) & 7.44 & 7.48 & 7.46 & 7.49 & 5.88 & 5.89 & 5.86 \\
\hline DUST Burden (TgC) & 43.87 & 45.04 & 45.03 & 45.20 & 42.60 & 42.75 & 42.31 \\
\hline SALT Burden (TgC) & 6.02 & 10.88 & 10.88 & 10.87 & 11.14 & 11.10 & 11.11 \\
\hline $\mathrm{SO}_{4}$ Burden $(\mathrm{TgS})$ & 0.45 & 0.49 & 0.49 & 0.49 & 0.51 & 0.51 & 0.51 \\
\hline $\mathrm{SO}_{4}$ Emis. $\left(\right.$ TgS year $\left.^{-1}\right)$ & 0.25 & 0.25 & 0.25 & 0.25 & 0.25 & 0.25 & 0.25 \\
\hline $\mathrm{SO}_{4}$ Dry Dep. $\left(\mathrm{TgS} \mathrm{year}^{-1}\right)$ & 5.29 & 5.76 & 5.78 & 5.77 & 5.94 & 6.00 & 5.99 \\
\hline $\mathrm{SO}_{4}$ Wet Dep. $\left(\mathrm{TgS}\right.$ year $\left.^{-1}\right)$ & -49.93 & -46.36 & -46.28 & -46.30 & -46.36 & -46.42 & -46.49 \\
\hline $\mathrm{SO}_{4}$ Chem. Prod. $\left(\mathrm{TgS}\right.$ year $\left.{ }^{-1}\right)$ & 10.35 & 10.81 & 10.83 & 10.82 & 10.98 & 11.02 & 11.02 \\
\hline $\mathrm{SO}_{4}$ AQ. Prod. (TgS year $\left.{ }^{-1}\right)$ & 44.95 & 41.41 & 41.34 & 41.35 & 41.44 & 41.53 & 41.58 \\
\hline $\mathrm{SO}_{4}$ Total Prod. $\left(\mathrm{TgS}_{\text {year }}{ }^{-1}\right)$ & 55.30 & 52.23 & 52.17 & 52.18 & 52.42 & 52.55 & 52.60 \\
\hline $\mathrm{SO}_{4}$ Lifet. (days) & 2.97 & 3.41 & 3.42 & 3.41 & 3.52 & 3.54 & 3.53 \\
\hline
\end{tabular}



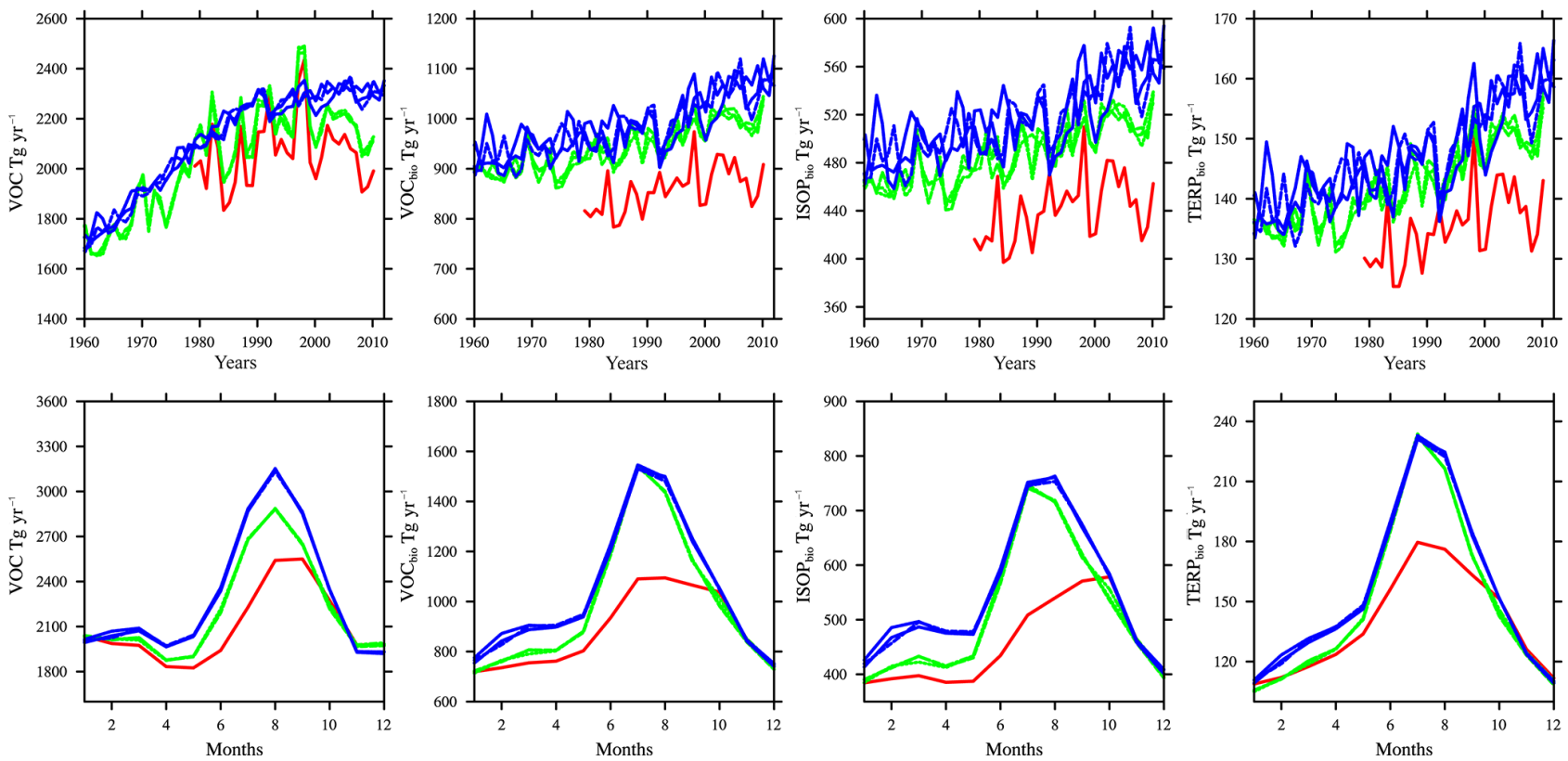

Figure 1. Global-averaged surface emissions of total volatile organic compounds (VOCs) (first column), biogenic VOCs (second column), biogenic isoprene (third column), and biogenic terpenes (fourth column), for different experiments, REFC1SD (red), REFC1 (green), REFC2 (blue). The seasonal cycle of zonal averages between 1960 and 2010 are shown at the bottom row.

\subsection{Trends of tropospheric components}

Time-varying emissions of ozone precursors and aerosols impact the oxidation capacity of the atmosphere. In the following, we discuss the evolution of different chemical species and surface area density in the tropical troposphere between $30^{\circ} \mathrm{S}$ and $30^{\circ} \mathrm{N}$, tropospheric methane lifetime and stratospheric column ozone (Fig. 2), since methane is mostly controlled by processes in the tropics. Increasing nitrogen dioxide $\left(\mathrm{NO}_{2}\right), \mathrm{CO}$ and VOC burdens between 1960 and 1990 result in increasing tropospheric ozone with the strongest trend between 1960 and 1990. Increasing aerosols between 1960 and 1990 result in an increase in SAD, with little change after 1990. Together with the increase in CO burden, this results in a decrease of $\mathrm{OH}$. Other factors result in an increase in tropospheric $\mathrm{OH}$, including decreasing stratospheric column ozone between 1960 and 2010, increasing tropospheric column ozone, increasing nitrogen dioxides $\left(\mathrm{NO}_{x}\right)$ burden, and decreasing methane emissions (e.g., Murray et al., 2014). Both counteracting effects on $\mathrm{OH}$ result in little change in methane lifetime between 1960 and 1990. After 1990, SAD, as well as CO and VOC, trends are leveling off, but nitrogen dioxide and ozone burdens are still increasing, partly due to increasing lightning $\mathrm{NO}_{x}$ production (not shown). This results in a decreasing trend in methane lifetime after 1990 for all reference experiments.

The burden of chemical tracers differs between REFC1SD and REFC1/REFC2 (Fig. 2). Variations in emissions and atmospheric dynamics, including surface temperature, clouds and convection, influence the chemical composition of the atmosphere. Exchange processes between the upper troposphere and lower stratosphere are also different in the model experiments and impact ozone. The shorter lifetime of methane in REFC1SD compared to the other experiments may be a result of a reduction in high clouds, and, to some amount, the larger ozone mixing ratios in the tropical troposphere, which would increase the oxidation capacity in the tropics. This has to be investigated in more detail in future studies.

Besides a continuous decrease, the stratospheric ozone column shows a significant drop after major volcanic eruptions (e.g., WMO, 2006). This is expected due to an increase in stratospheric SAD after the eruption, which causes enhanced halogen activation, resulting in ozone depletion (see Fig. 2).

\section{Evaluation against selected diagnostics}

The purpose of this section is to give an overview of selected variables and diagnostics that summarize the performance of the model, including some of its shortcomings, in comparison to observations. Additional and more detailed investigations are expected in future multi-model comparison studies. We only discuss the performance of the reference experiments for past and present day. Model results from other sensitivity studies are not analyzed and will be discussed in future studies. 

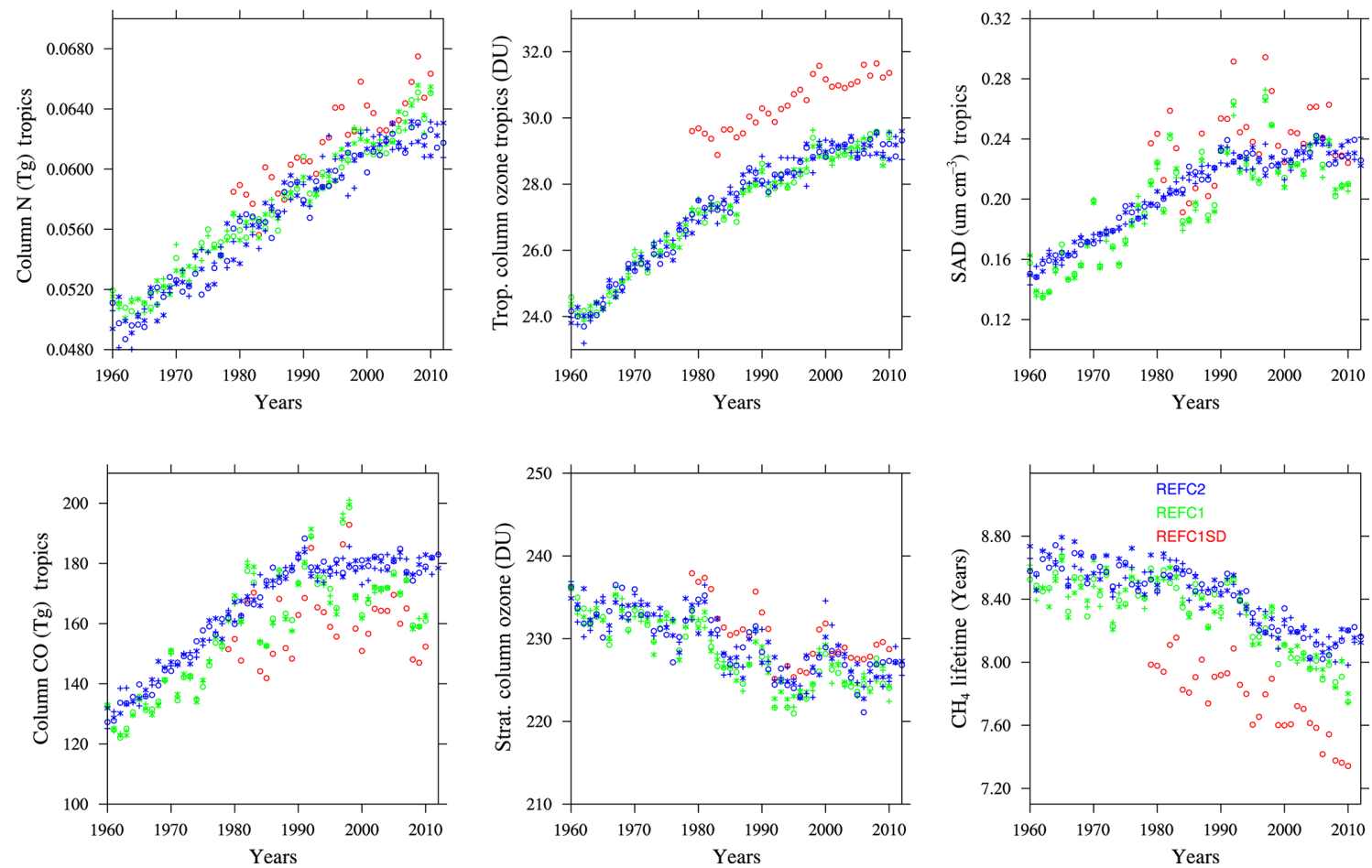

Figure 2. Time series of annually averaged column integrated tropospheric and tropical nitrogen dioxide (in Tg N), tropospheric ozone burden, and $\mathrm{CO}$, in $\left(30^{\circ} \mathrm{S}-30^{\circ} \mathrm{N}\right)$, tropical average of tropospheric surface area density, global stratospheric column ozone and tropospheric methane lifetime.

\subsection{Ozone}

Ozone is an important atmospheric tracer in both the troposphere and the stratosphere. In the troposphere and at the surface, ozone is an air pollutant and is impacted by various precursors, most importantly $\mathrm{CO}$ and $\mathrm{NO}_{x}$. A reasonable performance of tropospheric ozone is required for air quality studies. In the stratosphere, ozone is strongly influenced by dynamics, photo-chemistry and catalytic reactions (e.g., WMO, 2011). The strength of the transport of stratospheric ozone into the troposphere follows a seasonal cycle controlled by the Brewer-Dobson circulation (BDC). Shortcomings in the representation of the strength of the BDC and mixing processes between stratosphere and troposphere influence the performance of tropospheric ozone, as discussed below. In addition, ozone is an important greenhouse gas in the upper troposphere and lower stratosphere (UTLS) and influences tropospheric climate (e.g., WMO, 2014).

\subsubsection{Trends and seasonality of ozone}

Ozone trends and seasonality in the reference experiments are compared to ozonesonde observations (Tilmes et al., 2012) in the free troposphere (at $500 \mathrm{hPa}$ ) and the boundary layer (at $900 \mathrm{hPa}$ ). For Japan, we employ an additional climatology derived by Tanimoto et al. (2015), which is based on surface observations at five marine boundary layer sites from the Acid Deposition Monitoring Network in East Asia (EANET) for pressure levels larger than $900 \mathrm{hPa}$, and a combination of the historical Measurements of OZone, water vapor, carbon monoxide and nitrogen oxides by inservice AIrbus airCraft (MOZAIC; URL: http://www.iagos. fr/mozaic) data (over Narita airport) and ozonesonde observations (at Tateno/Tsukuba) for pressure levels between 472 and $616 \mathrm{hPa}$. We use an artificial stratospheric ozone tracer $\left(\mathrm{O}_{3} \mathrm{~S}\right)$ to identify differences in stratosphere-troposphere exchange (STE) between different model experiments for four selected regions (see Figs. 3 and 4).

In high northern latitudes, REFC1SD reproduces the magnitude and trend of ozone very well, including variability within the standard deviation of the observations for all seasons, as shown in the example of the Northern Hemisphere (NH) polar west region (Fig. 3, first and second row). A very good agreement between the model experiment and ozonesondes also exists for western Europe, with the exception of the high bias between October and February at $500 \mathrm{hPa}$ of 5-10 ppb (Fig. 3, third and fourth row).

Results from REFC1 and REFC2 show larger deviations from the observations than REFC1SD over these two regions. These are in part due to not only differences in the amount of stratospheric ozone entering the troposphere for the different experiments (see Fig. 3, right column, dashed lines), but also changes in ozone loss and production. Discrepancies in ozone between the experiments can be ex- 

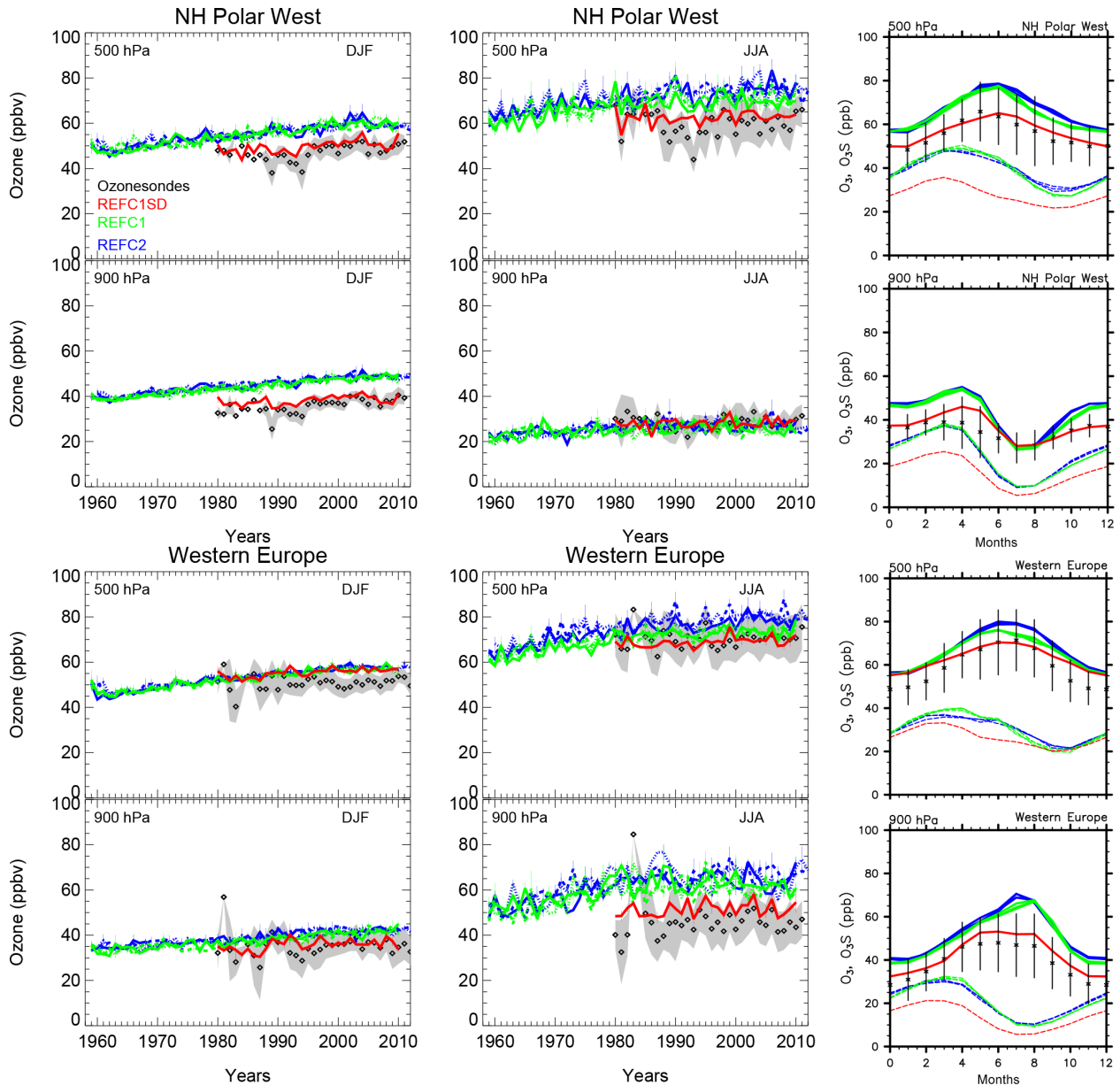

Figure 3. Left and middle column: time evolution of seasonal averaged and regionally aggregated ozone mixing ratios derived from ozone soundings (black diamonds) and model results (colored lines) at two different pressure levels, two different seasons (DJF: left, JJA: right) and regions ( $\mathrm{NH}$ polar west, and western Europe). Grey shading indicates the standard deviation of the observations that include at least 12 observed profiles per season in a year. Colored error bars indicate the standard deviation based on monthly averaged model output. Right column: Regionally aggregated seasonal cycle comparisons of ozone soundings (black lines) and model simulations (colored lines), averaged between 1995 and 2010. Dashed lines indicate mixing ratios of the stratospheric ozone tracer (see text for more details).

plained by differences in $\mathrm{O}_{3} \mathrm{~S}$ for the whole year at $500 \mathrm{hPa}$ and for winter months at $900 \mathrm{hPa}$. During summer months, differences in chemical production at the surface for the different experiments seem to play an additional role and explain about 5-10 ppb of the deviations for western Europe.

Selected ozonesondes over eastern USA and Japan are located further south and are more strongly influenced by tropical air masses and tropospheric intrusion in the lowermost stratosphere in particular in winter, as discussed in Tilmes et al. (2012). Each of the regions covers only two stations and so uses fewer observations for the different years than other regions, which increases the uncertainty of trends (Saunois et al., 2012).

Comparisons for eastern USA and Japan are illustrated in Fig. 4. For Japan, we are using two data sets to compare to model results. Ozone mixing ratios and trends at $900 \mathrm{hPa}$ over Japan using ozonesondes, as compiled by Tilmes et al.
(2012), Fig. 4 (black diamonds), largely differ from the climatology by Tanimoto et al. (2015), which is based on surface observations (black triangles). This is due to uncertainties in the ozonesonde observations at these altitudes, which should be treated with caution. On the other hand, the two climatologies agree well in the free troposphere at $500 \mathrm{hPa}$.

For eastern USA and Japan the REFC1SD model experiment nicely reproduces the observed trend and magnitude of ozone within the variability of the observations at $900 \mathrm{hPa}$. The seasonal cycle for both regions are well reproduced. This significant improvement compared to earlier versions of the model is in part a result of the improved calculation of dry deposition rates, as discussed in Val Martin et al. (2014) over the USA. REFC1 and REFC2 experiments show slightly larger values at $900 \mathrm{hPa}$ in comparison to the REFC1SD experiment particularly in winter, aligned with a larger $\mathrm{O}_{3}$ contribution from the stratosphere, as determined by the $\mathrm{O}_{3} \mathrm{~S}$ 

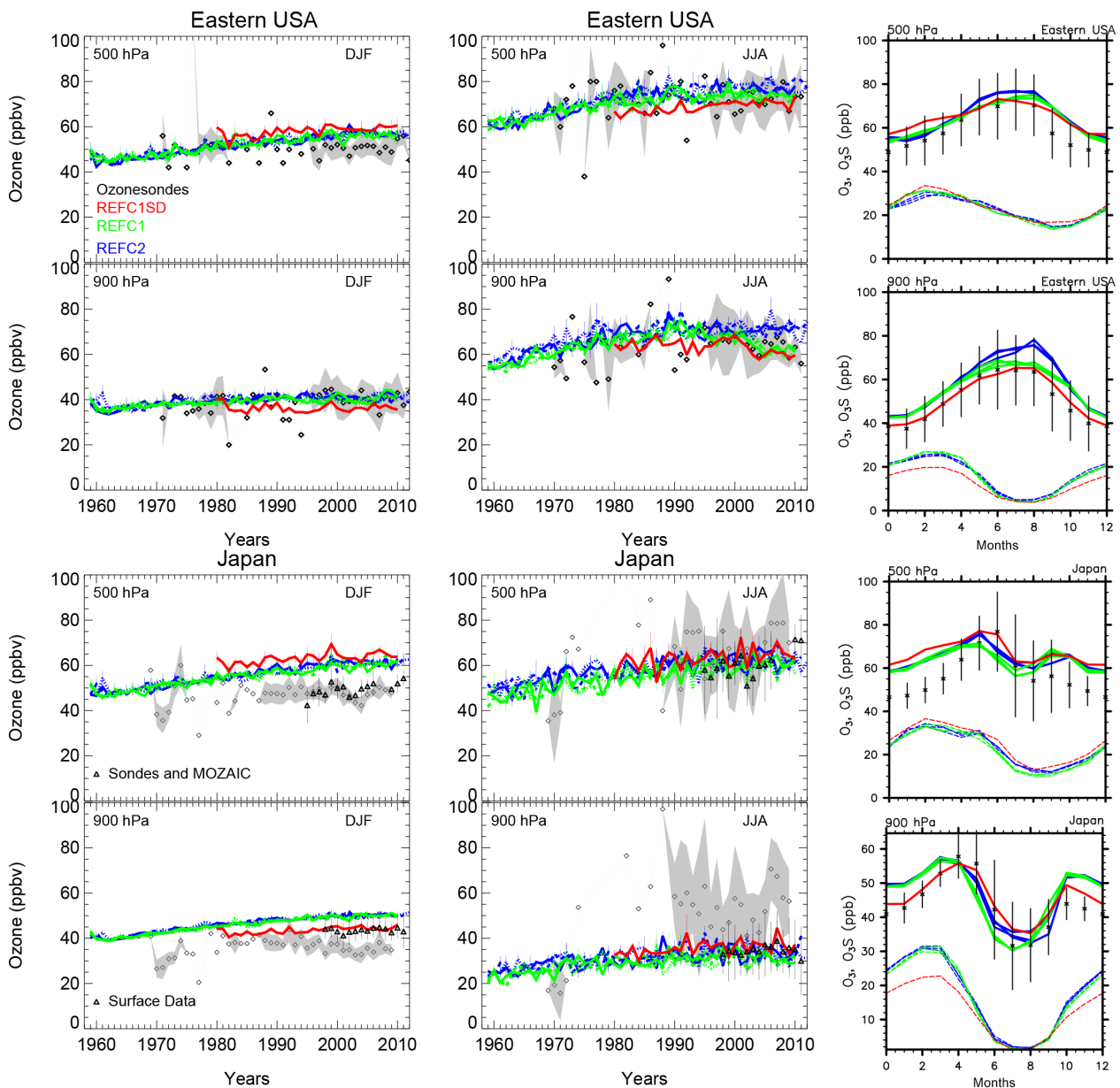

Figure 4. As Fig. 3, but for Eastern USA and Japan instead. For Japan, ozone time series compiled by Tanimoto et al. (2015) are added (black triangles) (see text for more details) and used to compare with the seasonal cycle of the model for Japan.

tracer (see Fig. 4). At $500 \mathrm{hPa}$, ozone mixing ratios and trends are well reproduced for all experiments in summer. However, the model overestimates winter ozone mixing ratios in the upper troposphere.

\subsubsection{Present-day ozone}

A comparison with ozonesonde observations over different regions for simulated years between 1995 and 2010 is presented in Fig. 5. Besides some differences in ozone compared to observations, as discussed above, all model experiments reproduce observed tropospheric ozone within $25 \%$ for most of the regions. At $250 \mathrm{hPa}$, which is the UTLS at mid- and high latitudes, REFC1SD overestimates ozone by up to $50 \%$, particularly at mid-latitudes in both hemispheres. This could be the result of strong mixing in the UTLS associated with the use of the small nudging amount of $1 \%$ in this study; however, this needs to be investigated in more detail in future studies. The other experiments show smaller deviations from the observations of about $20 \%$ or less. Tropical values at $50 \mathrm{hPa}$ are overestimated by no more than $20 \%$ compared to observations for all the experiments, while ozone in the mid- and high latitudes in the stratosphere agrees within $10 \%$ with observations.

Model results further agree well with HIPPO aircraft observations for profiles sampled from $85^{\circ} \mathrm{N}$ to $65^{\circ} \mathrm{S}$ over the Pacific Ocean between 2009 and 2011 (Fig. A2). In REFC1SD, lower troposphere values $(1-2 \mathrm{~km})$ are within the range of the observations, while for REFC1 and REFC2 ozone is overestimated by about $5 \mathrm{ppb}$ in high northern latitudes, in particular in winter and spring, which points to a transport problem as discussed above. Some differences, especially at higher altitudes $(7-8 \mathrm{~km})$ are likely caused by the specific meteorological situation for the flight conditions compared to the climatological model results.

The regional performance of tropospheric ozone in the model is further illustrated in Fig. 6, comparing simulated ozone mixing ratios with ozone sondes and various aircraft observations at $3-7 \mathrm{~km}$, as compiled in Tilmes et al. (2015). Observed features, for example the summertime maximum of ozone over eastern Mediterranean/Middle East 


\section{Comparison to Ozonesondes}
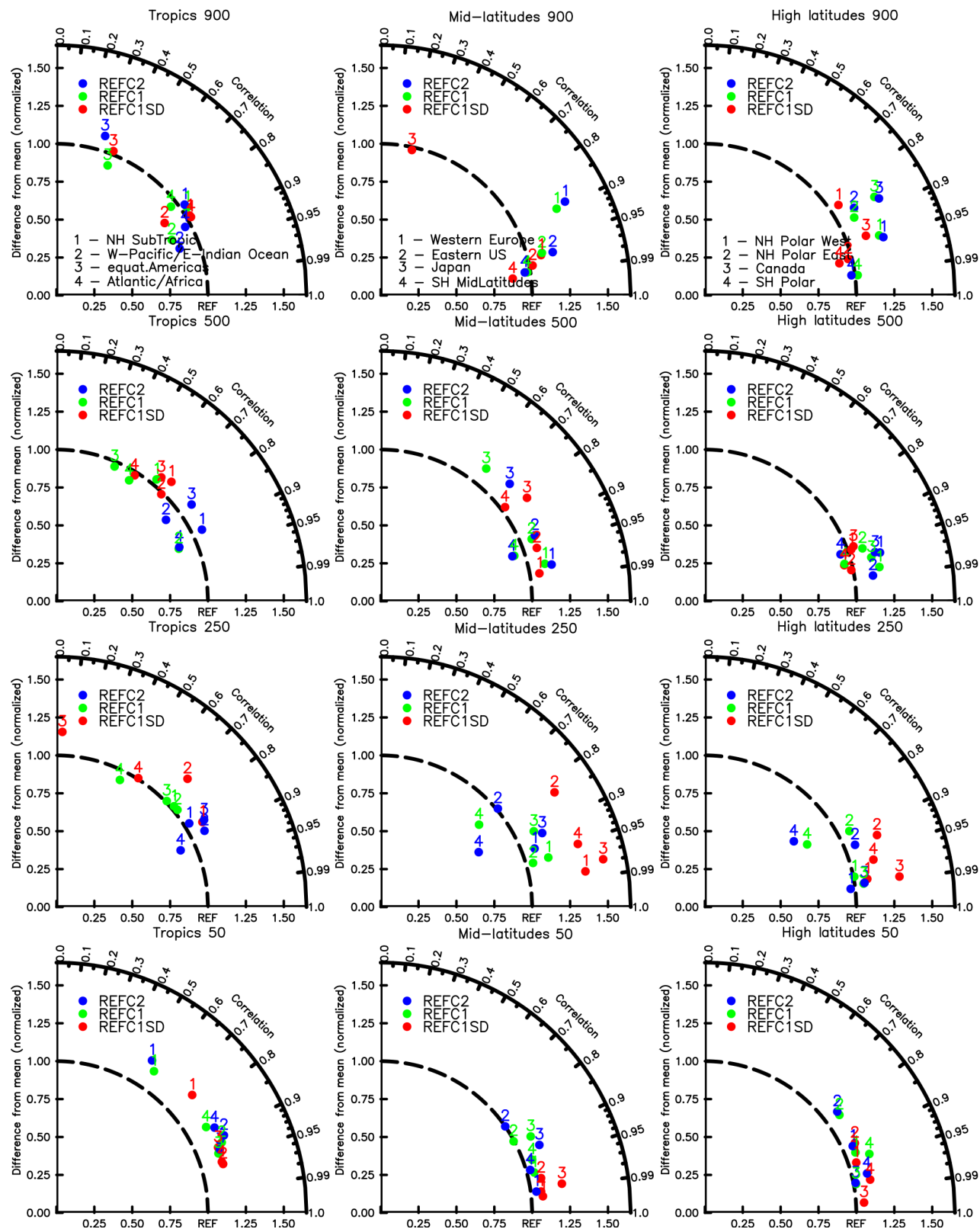

Figure 5. Taylor-like diagram comparing the mean and correlation of the seasonal cycle between observations using a present-day ozonesonde climatology between 1995 and 2011 and model results between 1995 and 2010, interpolated to the same locations as sampled by the observations and for different pressure levels, $900 \mathrm{hPa}$ (top panel), $500 \mathrm{hPa}$ (second panel), $250 \mathrm{hPa}$ (third panel) and $50 \mathrm{hPa}$ (bottom panel). Different numbers correspond to a specific region, as defined in Tilmes et al. (2012). Left panels: 1 - NH-subtropics; 2 W-Pacific/eastern Indian Ocean; 3 - equat. Americas; 4 - Atlantic/Africa. Middle panels: 1 - western Europe; 2 - eastern USA; 3 - Japan; 4 - SH mid-latitudes. Right panels: 1 - NH polar west; 2 - NH polar east; 3 - Canada; 4 - SH polar.

(Kalabokas et al., 2013; Zanis et al., 2014), are reproduced by the REFC1 and REFC1SD experiments. The ozone gradient between mid-latitudes and tropics is for the most part well captured, for example over Japan in summer. The pole to mid-latitude ozone gradient in the SD simulation showed a larger southward ozone gradient than the REFC1 simula- tion, which is more consistent with the measurements. Regional differences in tropospheric ozone between the different model experiments have to be investigated in future studies.

We further perform comparisons of model results to a present-day ozone climatology based on Ozone Monitor- 


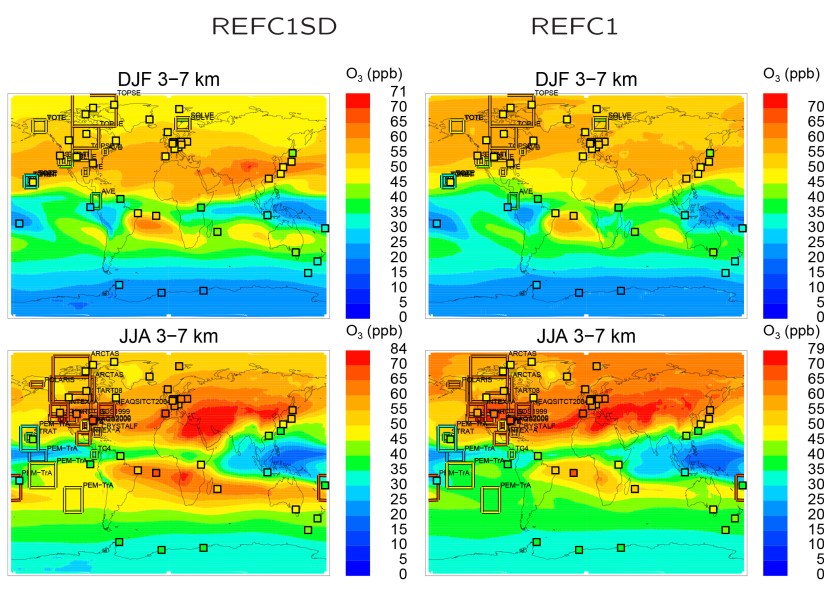

Figure 6. Comparison between model results in contours (REFC1SD left and REFC1.1 right) and observations of ozone mixing ratios, averaged over 3-7 km for December-January-February (DJF), top, and June-July-August (JJA), bottom. The color of each square represents the value of the observed ozonesonde measurement for the same period and altitude interval, and the color of framed regions corresponds to values derived from aircraft observations averaged over the particular region for each experiment (Tilmes et al., 2015).

ing Instrument (OMI) and Microwave Limb Sounder (MLS) satellite observations between 2004 and 2010, compiled by Ziemke et al. (2011), in the troposphere (Fig. 7) and stratosphere (Fig. 8). The model tropopause for this diagnostic is defined as the $150 \mathrm{ppb}$ ozone level, which may lead to small differences between observations and model simulations, but not between model experiments themselves. The comparisons reveal additional characteristics of the model performance compared to observations. Tropospheric column ozone is reproduced within $\pm 10 \mathrm{DU}$ of the observations, with a close agreement to the satellite climatology within less than \pm 5 DU in low and mid-latitudes in spring and summer (Fig. 7). All model experiments show a low bias in midlatitudes in the $\mathrm{SH}$ and high bias by $10-15 \mathrm{DU}$ in the $\mathrm{NH}$ mid-latitudes in winter and fall. NH tropospheric ozone is in general large in the REFC1 and REFC2 simulations compared to the REFC1SD experiments, as discussed above.

Stratospheric ozone in all model experiments agree within \pm 30 DU in mid- and low latitudes compared to the satellite climatology (Fig. 8). Larger deviations from the observations occur in the NH mid- and high latitudes in winter and spring with a high bias of up to $60 \mathrm{DU}$. Ozone in the SH is within about $25 \mathrm{DU}$ from the observations and is reasonably well reproduced by all model experiments, especially for the freerunning experiments.

\subsection{Carbon monoxide}

Carbon monoxide, non-methane hydrocarbons and nitrogen dioxides are the most important precursors to the formation
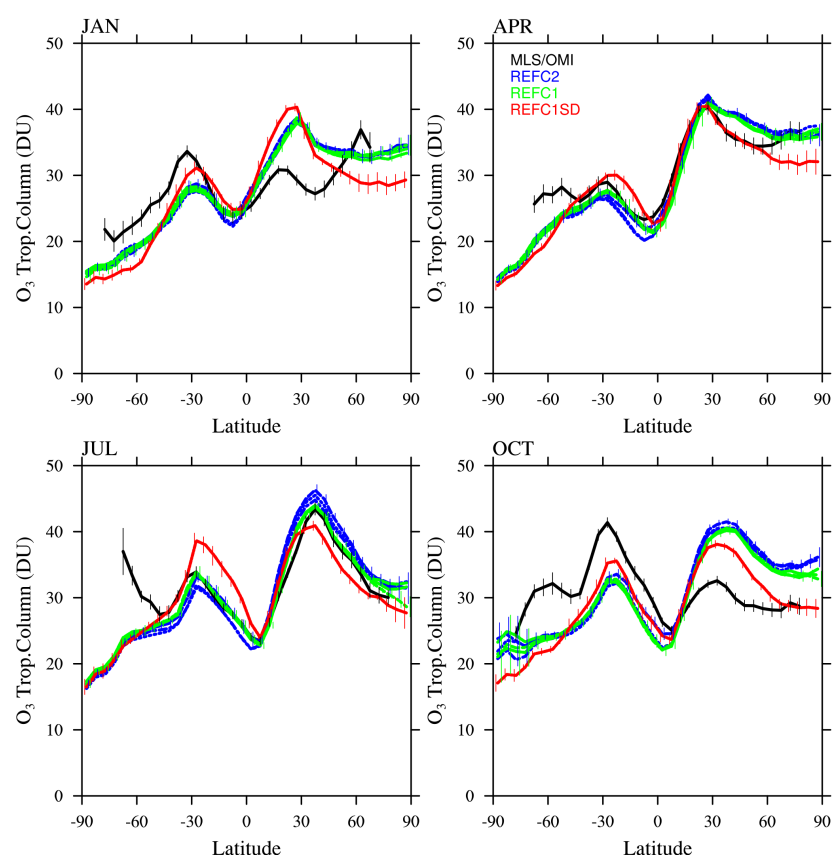

Figure 7. Monthly and zonally averaged tropospheric ozone column (in DU) comparison between OMI/MLS observations (black) and different model experiments; see legend (for ozone $<150 \mathrm{ppb}$ in the model) for 4 months. Error bars describe the zonally averaged 2 sigma 6-year root mean square standard error of the mean at a giving grid point, derived from the $10^{\circ} \mathrm{N}$ to $10^{\circ} \mathrm{S}$ gridded product (Ziemke et al., 2011). Model results are interpolated to the same grid and error bars indicate the standard deviation of the interannual variability per latitude interval.

of tropospheric ozone. Carbon monoxide also impacts the oxidation capacity of the atmosphere and therefore methane lifetime. We compare the CO burden from different experiments to monthly and zonally averaged tropospheric column carbon monoxide derived from Measurements of Pollution in the Troposphere (MOPITT) version 6 level 3 satellite observations, as described in Tilmes et al. (2015) (see Fig. 9). The climatological averaging kernel and a priori is applied to both observations and model experiments in the same way.

The most obvious difference between observations and model results occurs in NH winter and spring. All model experiments are biased low by about one-third relative to observations, similar to results from the Atmospheric Chemistry and Climate Model Intercomparison Project (ACCMIP) (Naik et al., 2013; Lamarque et al., 2012). In summer and fall, the $\mathrm{CO}$ representation differs between different experiments, in agreement with differences in biogenic emissions. The lowest CO burden is simulated for the REFC1SD experiment, which also shows the lowest emissions of VOCs in summer (see Fig. 1). This may translate into lower CO values in fall. Furthermore, the tropospheric $\mathrm{OH}$ burden is significantly larger in REFC1SD compared to the other ex- 

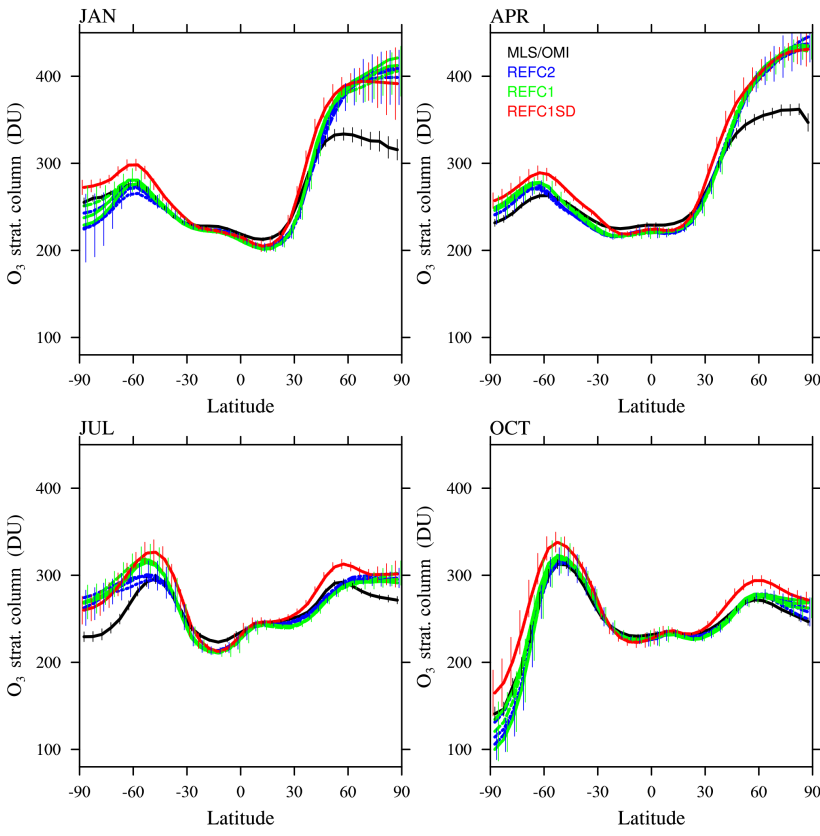

Figure 8. As Fig. 7, but showing monthly and zonally averaged stratospheric ozone column comparison between OMI/MLS observations (black) and different model experiments; see legend (for ozone $>150 \mathrm{ppb}$ in the model) for 4 months.

periments (not shown), which is consistent with more ozone in the tropical troposphere (see Fig. 2).

The simulated $\mathrm{CO}$ column in the tropics agrees with the satellite climatology within the interannual variability. However, the model underestimates CO column in the SH for all the experiments, in particular in summer. In contrast, comparisons to HIPPO CO in situ observations indicate very good agreement between $\mathrm{CO}$ mixing ratios in the $\mathrm{SH}$ over the remote region of the Pacific Ocean for most of the seasons (see Fig. A3). Furthermore, CO mixing ratios are largely underestimated in March and April in comparison to the aircraft observations, consistent with the satellite comparison. Differences in $\mathrm{CO}$ will be investigated in more detail in future studies.

\subsection{Hydrocarbons}

Hydrocarbons are important tropospheric compounds that are emitted from vegetation, biomass burning and anthropogenic sources, including oil and gas extraction activities. They are important ozone precursors, influence the oxidation capacity of the atmosphere, and eventually form CO.

Ethane and other hydrocarbons have been measured using canister samples along coastal and island sites in the Pacific Ocean since 1984 typically every 3 months, December, March, June and September (Simpson et al., 2012); data are available at http://cdiac.ornl.gov/trends/otheratg/blake/blake. html. We have compiled a climatology using ethane mixing ratios between 1995 and 2010 that covers latitudes between
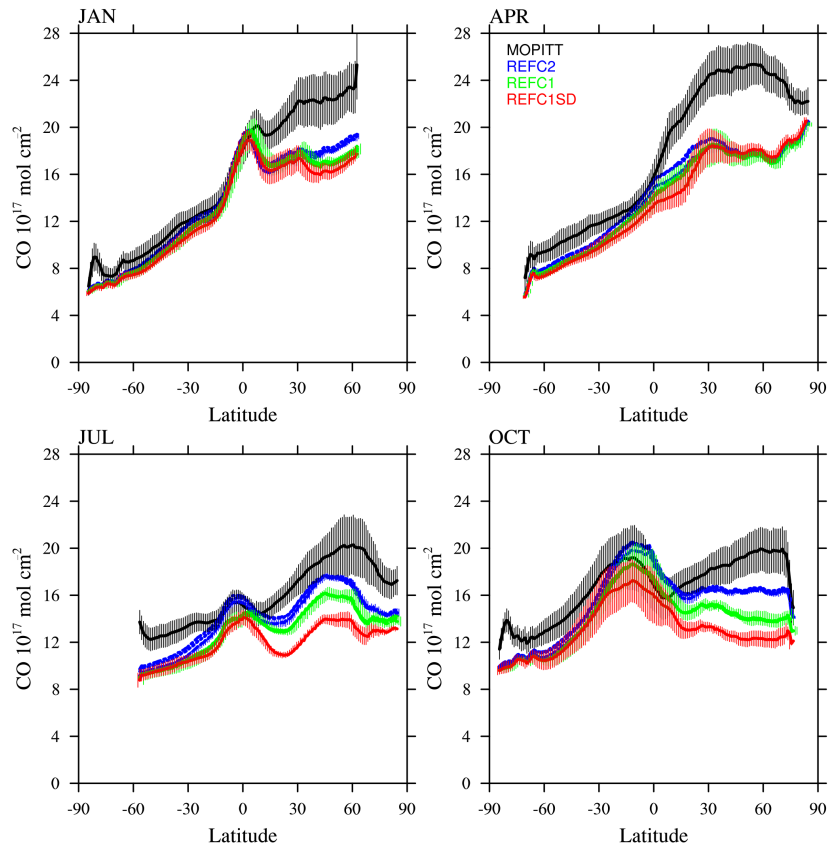

Figure 9. Monthly and zonally averaged tropospheric $\mathrm{CO}$ column comparison (in molec. $\mathrm{cm}^{-2}$ ) between MOPITT satellite observations (black) and different model experiments; see legend (for ozone $<150 \mathrm{ppb}$ in the model) for 4 months. Error bars for observations and model experiments show the standard deviation of the interannual variability per latitude interval.
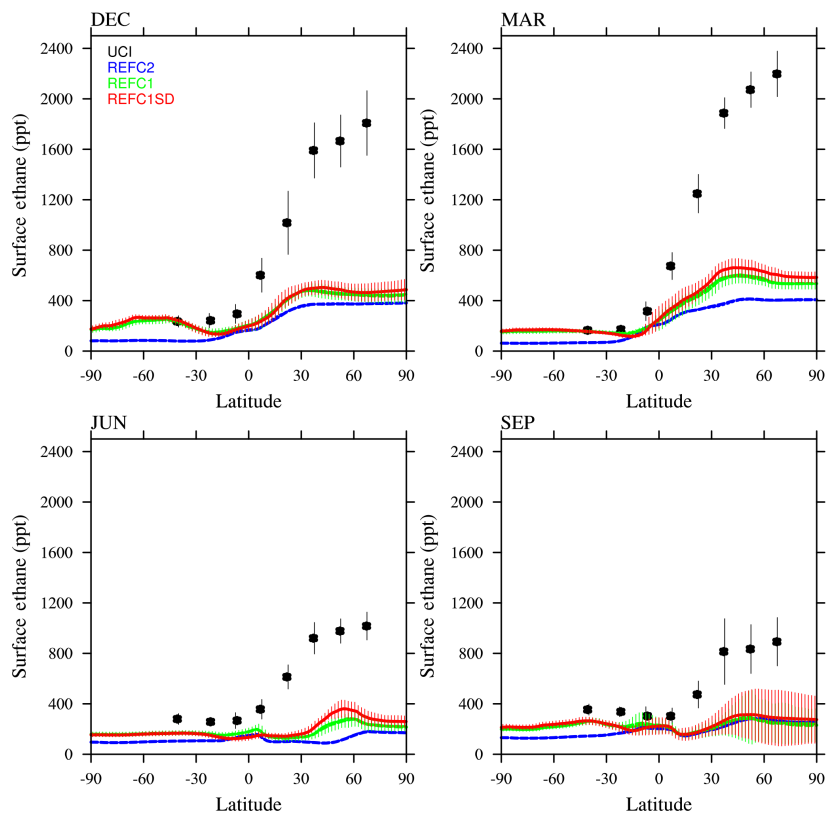

Figure 10. Comparison of observed and modeled surface ethane $\left(\mathrm{C}_{2} \mathrm{H}_{6}\right)$ mixing ratios in each season averaged over 1995-2010 along the length of the Pacific Ocean. Monthly mean CAM4-chem ethane mixing ratios at $190^{\circ} \mathrm{E}$ are shown for the three model experiments. 

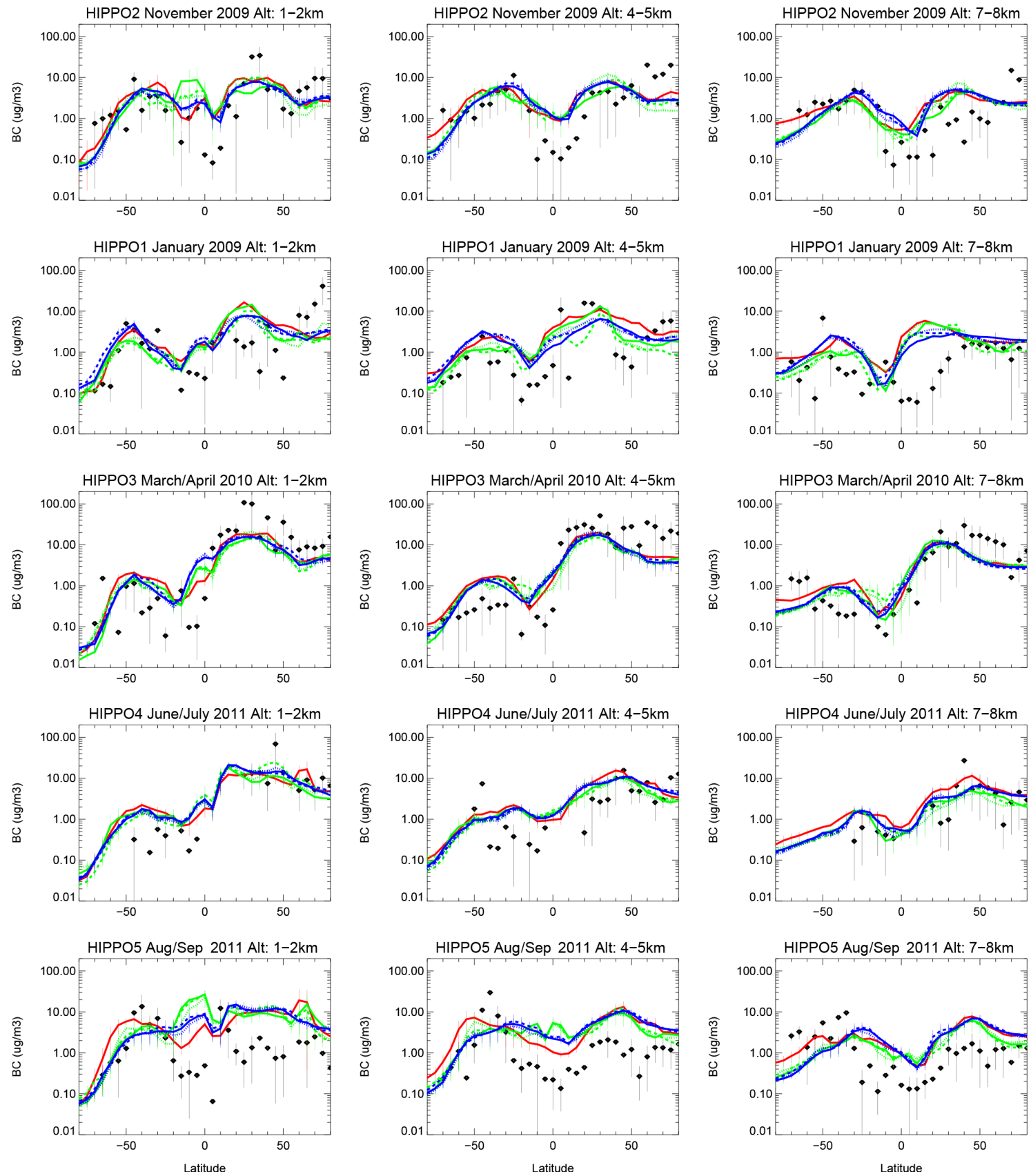

Figure 11. Black carbon comparison between different HIPPO aircraft campaigns taken over the Pacific Ocean (black symbols) and results from the reference simulations REFC1SD (red), REFC1 (green), REFC2 (blue), averaged over different altitude intervals. The sampled aircraft profiles during different HIPPO campaigns were averaged over $5^{\circ}$ latitude intervals along the flight path over the Pacific Ocean and compared to model output averaged over the same grid points, as done in Tilmes et al. (2015). The average profiles are averaged over three altitudes regions, $1-2,4-5$ and $7-8 \mathrm{~km}$. 
$50^{\circ} \mathrm{S}$ and $75^{\circ} \mathrm{N}$ (shown in Fig. 10). Comparisons to the three model experiments reveal a very large underestimation of ethane mixing ratios by up to $80 \%$ in spring. The smallest deviations occur in NH fall. These deviations are likely contributing to the underestimation of $\mathrm{CO}$ and overestimation of $\mathrm{OH}$.

While there is significant uncertainty in the speciation of VOC emissions (e.g., Li et al., 2014), which could lead to this discrepancy, it is likely there is an underestimation of all VOC emissions. Globally, ethane concentrations have been declining since long-term global record keeping began. Simpson et al. (2012) reported a $21 \%$ decline in global ethane concentrations from 1984 to 2010, which is much smaller than the discrepancy between the model and observations.

\subsection{Aerosols}

A reasonable description of aerosols in climate models, including interactions with chemistry and clouds, is important for the representation of radiative processes. The aerosol optical depth, global aerosol burden of organic matter, black carbon and sulfate aerosol are global diagnostics to evaluate the general performance of aerosol processes (Table 1). This version of CAM4-chem produces values for these diagnostics very similar to earlier model studies using CAM4chem (e.g., Tilmes et al., 2015). Here, we focus on the evaluation of background black carbon in comparison to HIPPO observations. The HIPPO campaign between 2009 and 2011 provided a comprehensive data set of black carbon over the remote region of the Pacific. Black carbon results from the model are averaged over the same locations, and altitude levels and compared to the observations, as described above.

All model simulations show a very similar distribution (Fig. 11), with only a few deviations from each other mostly in the $\mathrm{SH}$. The model reproduces $\mathrm{BC}$ values in the $\mathrm{SH}$ and $\mathrm{NH}$ mid-latitudes for most seasons within the range of uncertainty. A significant high bias in BC occurs in the tropics for all altitude levels and most seasons. Otherwise, in spring and summer, the hemispheric gradient of BC is represented well, following the observed larger burden in the $\mathrm{NH}$ compared to the $\mathrm{SH}$, with some overestimation in the $\mathrm{SH}$. The largest $\mathrm{BC}$ values in the $\mathrm{NH}$ spring are however underestimated. On the other hand, BC values in August/September, and partly November, are overestimated in the $\mathrm{NH}$ and in March/April and June/July in the SH.

\section{Conclusions}

The CESM1 CAM4-chem model has been used to perform the CCMI reference and sensitivity simulations. This paper provides an overview of the model setup of the reference experiments, including a detailed description of new developments. The most important improvements of the model be- yond what has been discussed in earlier studies (Lamarque et al., 2012; Tilmes et al., 2015) are the treatment of stratospheric aerosols and the corresponding radiation and optics, which is important for the free-running experiments (Neely et al., 2015). Further, the chemistry scheme has been updated to reaction rates of JPL 2010, and improved polar chemistry has been implemented (Wegner et al., 2013; Solomon et al., 2015). A new gravity wave description, while implemented incorrectly in the code, led to an improved representation of the evolution of polar stratospheric ozone in the SH. The updated dry deposition scheme by Val Martin et al. (2014) resulted in a much improved ozone near the surface, as also shown in Tilmes et al. (2015), and leads to a very good representation of ozone mixing ratios and trends in the REFC1SD simulation.

Global model diagnostics are investigated and a selected evaluation of key chemical species, including ozone, carbon monoxide, hydrocarbons and black carbon is performed. We limit our evaluation to present-day results of the REFC1SD, REFC1 and REFC2 experiments. Comparisons to observations are focused mostly on the troposphere. Nevertheless, stratospheric column ozone reproduces observed values, in particular in SH winter and spring, but overestimates values in the $\mathrm{NH}$ high latitudes.

For the troposphere, near-surface ozone mixing ratios and trends are very well reproduced and within $25 \%$ of the values from ozonesonde and satellite observations throughout the troposphere. A high bias in mid- and high northern latitudes for the REFC1 and REFC2 experiments can be explained by a stronger influence of stratospheric air masses compared to the REFC1SD simulation. This points to shortcomings in the stratosphere-troposphere exchange in the free-running simulations. On the other hand, the specified dynamics model experiment shows an overestimation of ozone in mid-latitude UTLS, as well as enhanced ozone in the upper tropical troposphere compared to the free-running experiments. The impact of shortcomings in the dynamical description of the model needs to be investigated in multi-model comparison studies.

Some biases in the model have not been resolved compared to earlier versions of the model (e.g., Tilmes et al., 2015). CO is still biased low in all model experiments in the $\mathrm{NH}$, especially in spring. Some differences between the experiments may be attributed to differences in biogenic emissions. Correspondingly, methane lifetime is low compared to observational estimates, which is likely related not only to shortcomings in emissions, but also to too large an oxidation capacity of the atmosphere. Significant shortcomings of hydrocarbons (shown for ethane) are identified in particular in the NH. The hemispheric gradient of BC in the model is reproduced well in most seasons, while the fall and winter values in mid-latitudes are often overestimated in mid-latitudes. $\mathrm{BC}$ in the tropics is largely overestimated for most seasons. This points to potential shortcomings in emissions, but also loss processes in the model. 


\section{Code and data availability}

The model code of the documented simulations is based on the Community Earth System Model, CESM version 1.1.1 (CESM1); http://www.cesm.ucar.edu/models/ cesm1.1/index.html. Modifications to the model code will be documented at http://www2.cesm.ucar.edu/models/ scientifically-supported. The data of the simulations are available for download at the NCAR Earth System Grid (ESG) (https://www.earthsystemgrid.org/home.html) and are submitted to the British Atmospheric Data Center (BADC) database for the CCMI project. 
Appendix A
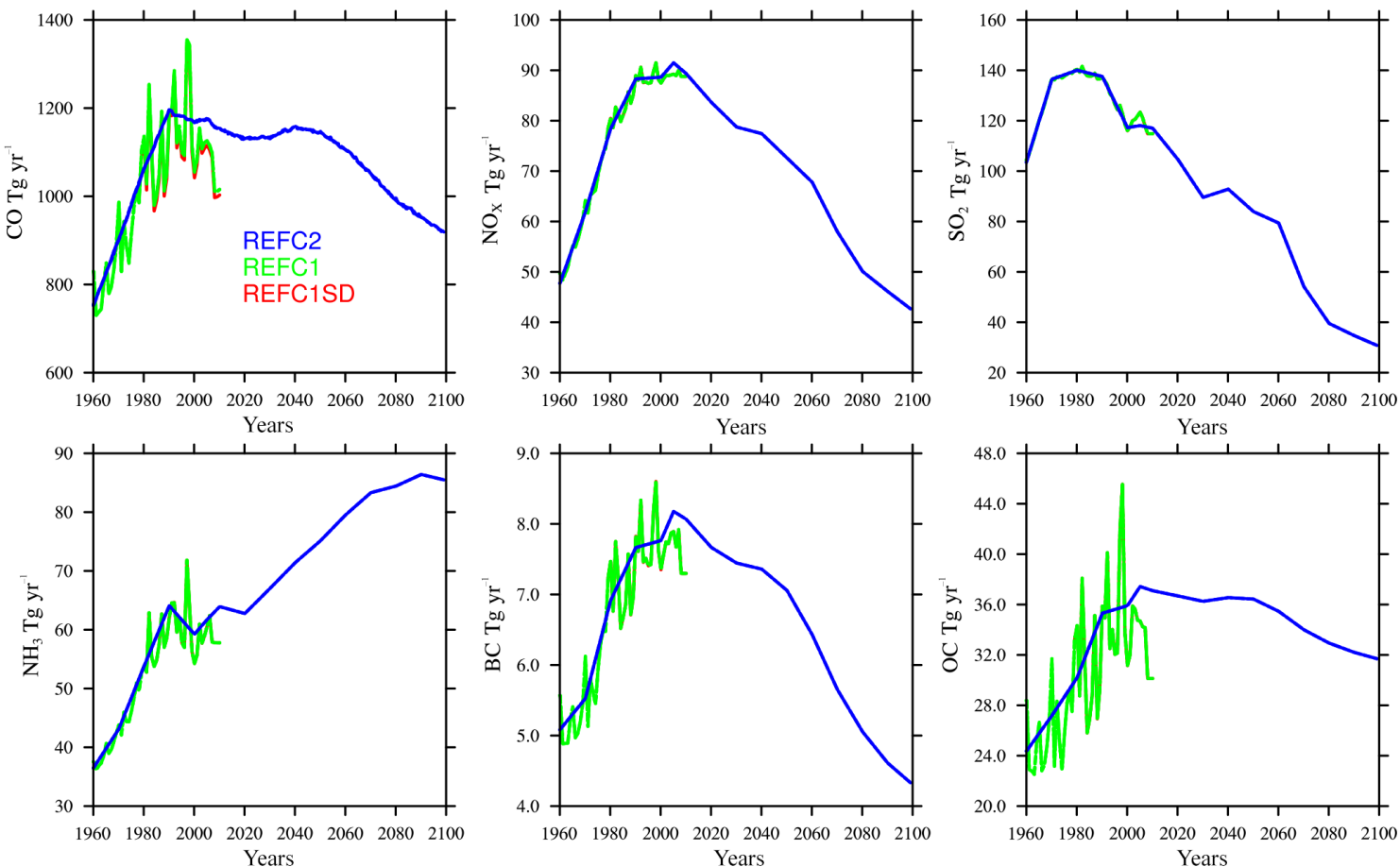

Figure A1. Selected surface emissions used for the different reference experiments. 

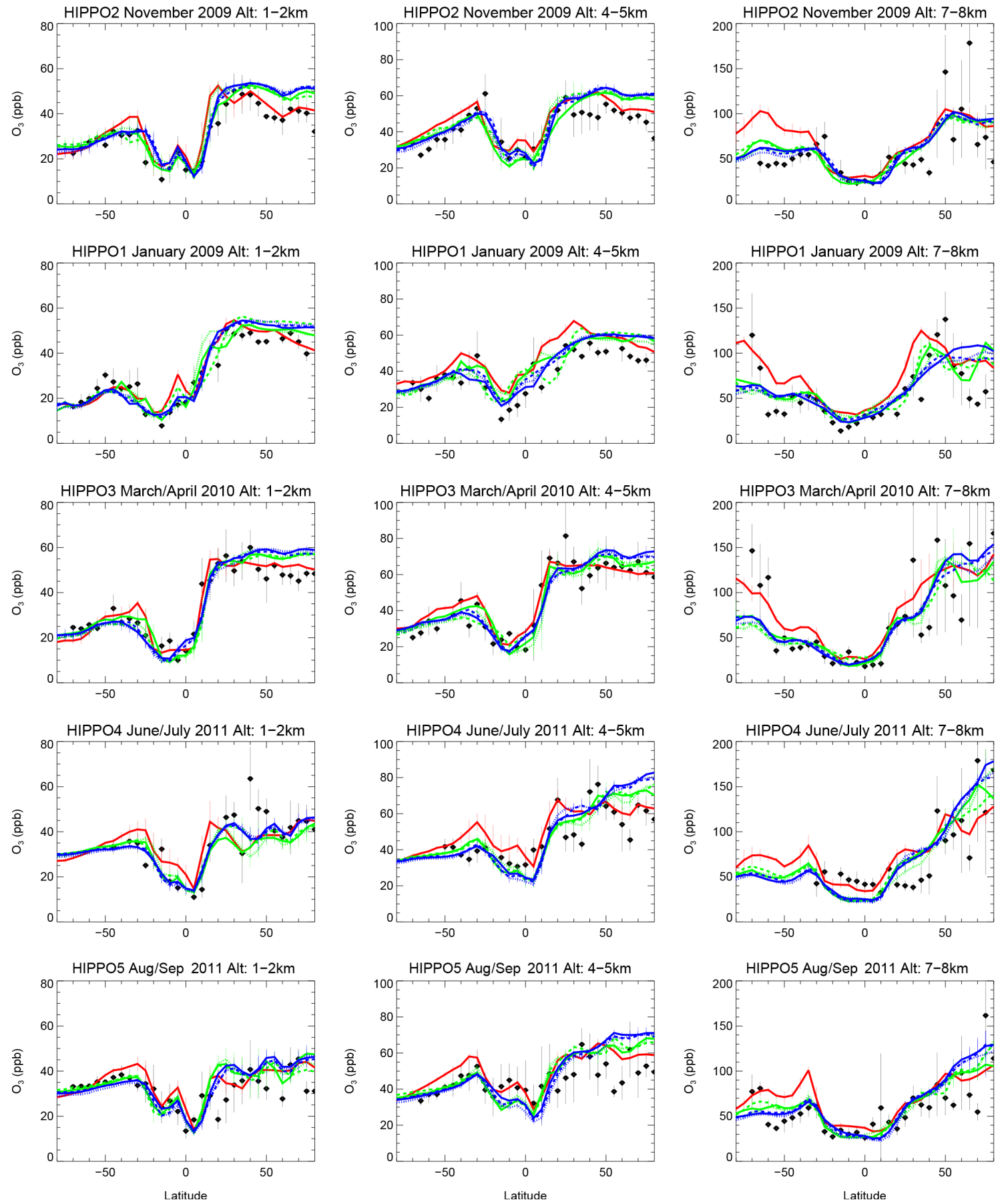

Figure A2. $\mathrm{O}_{3}$ comparison between different HIPPO aircraft campaigns taken over the Pacific Ocean (black symbols) and results from the reference simulations REFC1SD (red), REFC1 (green), REFC2 (blue), averaged over different altitude intervals. The sampled aircraft profiles during different HIPPO campaigns were averaged over $5^{\circ}$ latitude intervals along the flight path over the Pacific Ocean and compared to model output averaged over the same grid points, as done in Tilmes et al. (2015). The average profiles are averaged over three altitudes regions, $1-2,4-5$ and $7-8 \mathrm{~km}$. 

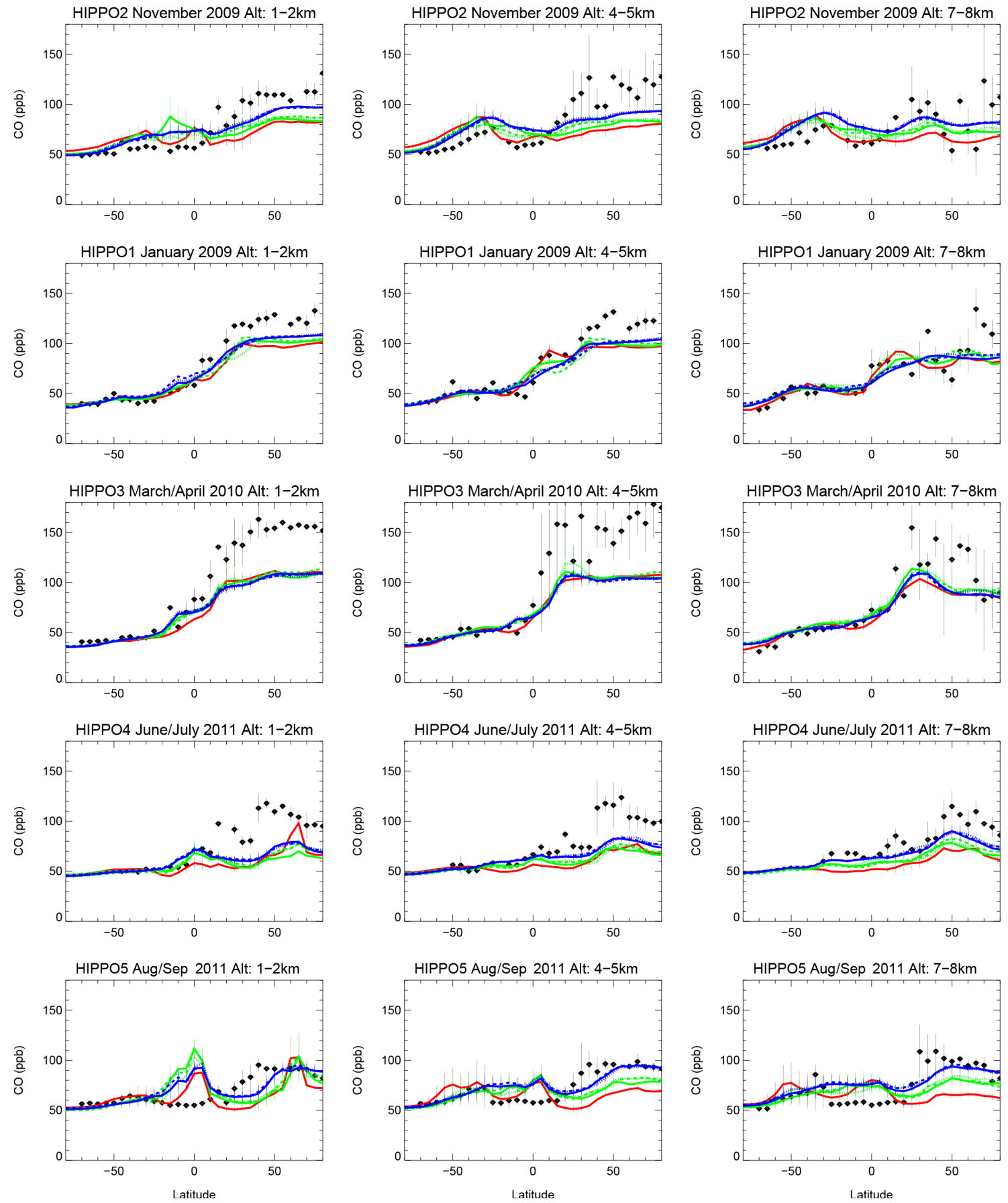

Figure A3. As Fig. A2, but for carbon monoxide. 
Table A1. Chemical species in CAM4-chem, chemical formula, solver (either explicit (E) or semi-implicit (I)), lower boundary conditions (LBC), and wet and dry deposition of species.

\begin{tabular}{|c|c|c|c|c|c|c|c|}
\hline No. & Species & Formula & Solver & Emis. & $\mathrm{LBC}$ & Wet dep. & Dry dep \\
\hline 1 & ALKO2 & $(\mathrm{C} 5 \mathrm{H} 11 \mathrm{O} 2)$ & I & & & & \\
\hline 2 & ALKOOH & (C5H12O2) & I & & & $\mathrm{X}$ & $X$ \\
\hline 3 & BENO2 & (C6H7O3) & I & & & & \\
\hline 4 & BENOOH & (C6H8O3) & I & & & & \\
\hline 5 & BENZENE & (C6H6) & I & $X$ & & & \\
\hline 6 & BIGALD & (C5H6O2) & I & $\mathrm{X}$ & & & \\
\hline 7 & BIGALK & (C5H12) & I & $\mathrm{X}$ & & & \\
\hline 8 & BIGENE & (C4H8) & I & $X$ & & & \\
\hline 9 & $\mathrm{BR}$ & $(\mathrm{Br})$ & I & & & & \\
\hline 10 & BRCL & $(\mathrm{BrCl})$ & I & & & & \\
\hline 11 & BRO & $(\mathrm{BrO})$ & I & & & & \\
\hline 12 & BRONO2 & (BrONO2) & I & & & $\mathrm{X}$ & \\
\hline 13 & BRY & & E & & & & \\
\hline 14 & $\mathrm{C} 10 \mathrm{H} 16$ & & I & $\mathrm{X}$ & & & \\
\hline 15 & $\mathrm{C} 2 \mathrm{H} 2$ & & I & $\mathrm{X}$ & & & \\
\hline 16 & $\mathrm{C} 2 \mathrm{H} 4$ & & I & $X$ & & & \\
\hline 17 & $\mathrm{C} 2 \mathrm{H} 5 \mathrm{O} 2$ & & I & & & & \\
\hline 18 & $\mathrm{C} 2 \mathrm{H} 5 \mathrm{OH}$ & & I & $X$ & & $\mathrm{X}$ & $X$ \\
\hline 19 & $\mathrm{C} 2 \mathrm{H} 5 \mathrm{OOH}$ & & I & & & $\mathrm{X}$ & $X$ \\
\hline 20 & $\mathrm{C} 2 \mathrm{H} 6$ & & I & $X$ & & & \\
\hline 21 & C3H6 & & I & $\mathrm{X}$ & & & \\
\hline 22 & $\mathrm{C} 3 \mathrm{H} 7 \mathrm{O} 2$ & & I & & & & \\
\hline 23 & $\mathrm{C} 3 \mathrm{H} 7 \mathrm{OOH}$ & & I & & & $\mathrm{X}$ & $\mathrm{X}$ \\
\hline 24 & C3H8 & & I & $\mathrm{X}$ & & & \\
\hline 25 & CCL4 & (CCl4) & E & & $X$ & & \\
\hline 26 & CF2CLBR & (CF2ClBr) & E & & $\mathrm{X}$ & & \\
\hline 27 & CF3BR & (CF3Br) & E & & $\mathrm{X}$ & & \\
\hline 28 & CFC11 & (CFCl3) & E & & $\mathrm{X}$ & & \\
\hline 29 & CFC113 & $(\mathrm{CCl} 2 \mathrm{FCClF} 2)$ & E & & $\mathrm{X}$ & & \\
\hline 30 & CFC114 & (CClF2CClF2) & E & & $\mathrm{X}$ & & \\
\hline 31 & CFC115 & (CClF2CF3) & E & & $\mathrm{X}$ & & \\
\hline 32 & $\mathrm{CFC} 12$ & $(\mathrm{CF} 2 \mathrm{Cl} 2)$ & E & & $\mathrm{X}$ & & \\
\hline 33 & $\mathrm{CH} 2 \mathrm{BR} 2$ & $(\mathrm{CH} 2 \mathrm{Br} 2)$ & E & & $\mathrm{X}$ & & \\
\hline 34 & $\mathrm{CH} 2 \mathrm{O}$ & & I & $X$ & & $\mathrm{X}$ & $\mathrm{X}$ \\
\hline 35 & CH3BR & (CH3Br) & E & & $\mathrm{X}$ & & \\
\hline 36 & CH3CCL3 & $(\mathrm{CH} 3 \mathrm{CCl} 3)$ & E & & $\mathrm{X}$ & & \\
\hline 37 & $\mathrm{CH} 3 \mathrm{CHO}$ & & I & $\mathrm{X}$ & & $\mathrm{X}$ & $X$ \\
\hline 38 & CH3CL & $(\mathrm{CH} 3 \mathrm{Cl})$ & E & & $\mathrm{X}$ & & \\
\hline 39 & $\mathrm{CH} 3 \mathrm{CN}$ & & I & $\mathrm{X}$ & & $\mathrm{X}$ & $X$ \\
\hline 40 & $\mathrm{CH} 3 \mathrm{CO} 3$ & & I & & & & \\
\hline 41 & $\mathrm{CH} 3 \mathrm{COCH} 3$ & & I & $X$ & & $X$ & $\mathrm{X}$ \\
\hline 42 & $\mathrm{CH} 3 \mathrm{COCHO}$ & & I & & & $\mathrm{X}$ & $\mathrm{X}$ \\
\hline 43 & $\mathrm{CH} 3 \mathrm{COOH}$ & & I & $\mathrm{X}$ & & & $\mathrm{X}$ \\
\hline 44 & $\mathrm{CH} 3 \mathrm{COOOH}$ & & I & & & $\mathrm{X}$ & $X$ \\
\hline 45 & $\mathrm{CH} 3 \mathrm{O} 2$ & & I & & & & \\
\hline 46 & $\mathrm{CH} 3 \mathrm{OH}$ & & I & $\mathrm{X}$ & & $\mathrm{X}$ & $\mathrm{X}$ \\
\hline 47 & $\mathrm{CH} 3 \mathrm{OOH}$ & & I & & & $\mathrm{X}$ & $\mathrm{X}$ \\
\hline 48 & $\mathrm{CH} 4$ & & E & & X & & \\
\hline 49 & CHBR3 & (CHBr3) & E & & X & & \\
\hline 50 & CL & $(\mathrm{Cl})$ & I & & & & \\
\hline
\end{tabular}


Table A1. Continued.

\begin{tabular}{|c|c|c|c|c|c|c|c|}
\hline No. & Species & Formula & Solver & Emis. & LBC & Wet dep. & Dry dep. \\
\hline 51 & CL2 & (Cl2) & I & & & & \\
\hline 52 & CL2O2 & $(\mathrm{Cl} 2 \mathrm{O} 2)$ & I & & & & \\
\hline 53 & CLO & $(\mathrm{ClO})$ & I & & & & \\
\hline 54 & CLONO2 & (ClONO2) & I & & & $\mathrm{X}$ & \\
\hline 55 & CLY & & E & & & & \\
\hline 56 & $\mathrm{CO}$ & & I & $\mathrm{X}$ & & & $\mathrm{X}$ \\
\hline 57 & $\mathrm{CO} 2$ & & $\mathrm{E}$ & & $\mathrm{X}$ & & \\
\hline 58 & CRESOL & $(\mathrm{C} 7 \mathrm{H} 8 \mathrm{O})$ & I & & & & \\
\hline 59 & DMS & (CH3SCH3) & I & $\mathrm{X}$ & & & \\
\hline 60 & ENEO2 & (C4H9O3) & I & & & & \\
\hline 61 & EO & $(\mathrm{HOCH} 2 \mathrm{CH} 2 \mathrm{O})$ & I & & & & \\
\hline 62 & $\mathrm{EO} 2$ & $(\mathrm{HOCH} 2 \mathrm{CH} 2 \mathrm{O} 2)$ & I & & & & \\
\hline 63 & $\mathrm{EOOH}$ & $(\mathrm{HOCH} 2 \mathrm{CH} 2 \mathrm{OOH})$ & I & & & $\mathrm{X}$ & $\mathrm{X}$ \\
\hline 64 & GLYALD & (HOCH2CHO) & I & & & $\mathrm{X}$ & $\mathrm{X}$ \\
\hline 65 & GLYOXAL & $(\mathrm{C} 2 \mathrm{H} 2 \mathrm{O} 2)$ & I & & & & \\
\hline 66 & $\mathrm{H}$ & & I & & & & \\
\hline 67 & H1202 & $(\mathrm{CBr} 2 \mathrm{~F} 2)$ & $\mathrm{E}$ & & $\mathrm{X}$ & & \\
\hline 68 & $\mathrm{H} 2$ & & I & & $\mathrm{X}$ & & \\
\hline 69 & $\mathrm{H} 2402$ & $(\mathrm{CBrF} 2 \mathrm{CBrF} 2)$ & $\mathrm{E}$ & & $\mathrm{X}$ & & \\
\hline 70 & $\mathrm{H} 2 \mathrm{O}$ & & I & & & & \\
\hline 71 & $\mathrm{H} 2 \mathrm{O} 2$ & & I & & & $\mathrm{X}$ & $\mathrm{X}$ \\
\hline 72 & HBR & $(\mathrm{HBr})$ & I & & & $\mathrm{X}$ & \\
\hline 73 & HCFC141B & (CH3CCl2F) & $\mathrm{E}$ & & $\mathrm{X}$ & & \\
\hline 74 & HCFC142B & (CH3CClF2) & $\mathrm{E}$ & & $\mathrm{X}$ & & \\
\hline 75 & HCFC22 & $(\mathrm{CHF} 2 \mathrm{Cl})$ & E & & $\mathrm{X}$ & & \\
\hline 76 & HCL & $(\mathrm{HCl})$ & I & & & $\mathrm{X}$ & \\
\hline 77 & $\mathrm{HCN}$ & & I & $\mathrm{X}$ & & $\mathrm{X}$ & $\mathrm{X}$ \\
\hline 78 & $\mathrm{HCOOH}$ & & I & $\mathrm{X}$ & & $\mathrm{X}$ & $\mathrm{X}$ \\
\hline 79 & HNO3 & & I & & & $\mathrm{X}$ & $\mathrm{X}$ \\
\hline 80 & $\mathrm{HO} 2$ & & I & & & & \\
\hline 81 & $\mathrm{HO} 2 \mathrm{NO} 2$ & & I & & & $\mathrm{X}$ & $\mathrm{X}$ \\
\hline 82 & HOBR & $(\mathrm{HOBr})$ & I & & & $\mathrm{X}$ & \\
\hline 83 & $\mathrm{HOCH} 2 \mathrm{OO}$ & & I & & & & \\
\hline 84 & HOCL & $(\mathrm{HOCl})$ & I & & & $\mathrm{X}$ & \\
\hline 85 & HYAC & $(\mathrm{CH} 3 \mathrm{COCH} 2 \mathrm{OH})$ & I & & & $\mathrm{X}$ & $\mathrm{X}$ \\
\hline 86 & HYDRALD & (HOCH2CCH3CHCHO) & I & & & $\mathrm{X}$ & $\mathrm{X}$ \\
\hline 87 & ISOP & (C5H8) & I & $\mathrm{X}$ & & & \\
\hline 88 & ISOPNO3 & (CH2CHCCH3OOCH2ONO2) & I & & & $\mathrm{X}$ & \\
\hline 89 & ISOPO2 & (HOCH2COOCH3CHCH2) & I & & & & \\
\hline 90 & ISOPOOH & (HOCH2COOHCH3CHCH2) & I & & & $\mathrm{X}$ & $\mathrm{X}$ \\
\hline 91 & MACR & $(\mathrm{CH} 2 \mathrm{CCH} 3 \mathrm{CHO})$ & I & & & $\mathrm{X}$ & \\
\hline 92 & MACRO2 & $(\mathrm{CH} 3 \mathrm{COCHO} 2 \mathrm{CH} 2 \mathrm{OH})$ & I & & & & \\
\hline 93 & MACROOH & (CH3COCHOOHCH2OH) & I & & & $\mathrm{X}$ & $\mathrm{X}$ \\
\hline 94 & $\mathrm{MCO} 3$ & $(\mathrm{CH} 2 \mathrm{CCH} 3 \mathrm{CO} 3)$ & I & & & & \\
\hline 95 & MEK & $(\mathrm{C} 4 \mathrm{H} 8 \mathrm{O})$ & I & $\mathrm{X}$ & & & \\
\hline 96 & MEKO2 & (C4H7O3) & I & & & & \\
\hline 97 & MEKOOH & $(\mathrm{C} 4 \mathrm{H} 8 \mathrm{O} 3)$ & I & & & $\mathrm{X}$ & $\mathrm{X}$ \\
\hline 98 & MPAN & (CH2CCH3CO3NO2) & I & & & & $\mathrm{X}$ \\
\hline 99 & MVK & $(\mathrm{CH} 2 \mathrm{CHCOCH} 3)$ & I & & & $\mathrm{X}$ & \\
\hline 100 & $\mathrm{~N}$ & & I & & & & \\
\hline
\end{tabular}


Table A1. Continued.

\begin{tabular}{|c|c|c|c|c|c|c|c|}
\hline No. & Species & Formula & Solver & Emis. & LBC & Wet dep. & Dry dep. \\
\hline 101 & $\mathrm{~N} 2 \mathrm{O}$ & & $\mathrm{E}$ & & $\mathrm{X}$ & & \\
\hline 102 & $\mathrm{~N} 2 \mathrm{O} 5$ & & I & & & & \\
\hline 103 & $\mathrm{NH} 3$ & & I & $\mathrm{X}$ & & $\mathrm{X}$ & $\mathrm{X}$ \\
\hline 104 & NO & & I & $\mathrm{X}$ & & & $\mathrm{X}$ \\
\hline 105 & $\mathrm{NO} 2$ & & I & & & & $\mathrm{X}$ \\
\hline 106 & NO3 & & I & & & & \\
\hline 107 & $\mathrm{O}$ & & I & & & & \\
\hline 108 & O1D & (O) & I & & & & \\
\hline 109 & $\mathrm{O} 3$ & & I & & & & $\mathrm{X}$ \\
\hline 110 & OCLO & $(\mathrm{OClO})$ & I & & & & \\
\hline 111 & $\mathrm{OH}$ & & I & & & & \\
\hline 112 & ONIT & (CH3COCH2ONO2) & I & & & $\mathrm{X}$ & $\mathrm{X}$ \\
\hline 113 & ONITR & $(\mathrm{CH} 2 \mathrm{CCH} 3 \mathrm{CHONO} 2 \mathrm{CH} 2 \mathrm{OH})$ & I & & & $\mathrm{X}$ & $\mathrm{X}$ \\
\hline 114 & PAN & $(\mathrm{CH} 3 \mathrm{CO} 3 \mathrm{NO} 2)$ & I & & & & $\mathrm{X}$ \\
\hline 115 & $\mathrm{PO} 2$ & $(\mathrm{C} 3 \mathrm{H} 6 \mathrm{OHO} 2)$ & I & & & & \\
\hline 116 & $\mathrm{POOH}$ & $(\mathrm{C} 3 \mathrm{H} 6 \mathrm{OHOOH})$ & I & & & $\mathrm{X}$ & $\mathrm{X}$ \\
\hline 117 & $\mathrm{RO} 2$ & $(\mathrm{CH} 3 \mathrm{COCH} 2 \mathrm{O} 2)$ & I & & & & \\
\hline 118 & $\mathrm{ROOH}$ & $(\mathrm{CH} 3 \mathrm{COCH} 2 \mathrm{OOH})$ & I & & & $\mathrm{X}$ & $\mathrm{X}$ \\
\hline 119 & SF6 & & $\mathrm{E}$ & & $\mathrm{X}$ & & \\
\hline 120 & $\mathrm{SO} 2$ & & I & $\mathrm{X}$ & & $\mathrm{X}$ & $\mathrm{X}$ \\
\hline 121 & SOGB & (C6H7O3) & I & & & $\mathrm{X}$ & $\mathrm{X}$ \\
\hline 122 & SOGI & (CH3C4H9O4) & I & & & $\mathrm{X}$ & $\mathrm{X}$ \\
\hline 123 & SOGM & (C10H16O4) & I & & & $\mathrm{X}$ & $\mathrm{X}$ \\
\hline 124 & SOGT & (C7H9O3) & I & & & $\mathrm{X}$ & $\mathrm{X}$ \\
\hline 125 & SOGX & (C8H11O3) & I & & & $\mathrm{X}$ & $\mathrm{X}$ \\
\hline 126 & TERPO2 & (C10H17O3) & I & & & & \\
\hline 127 & TERPOOH & $(\mathrm{C} 10 \mathrm{H} 18 \mathrm{O} 3)$ & I & & & $\mathrm{X}$ & $\mathrm{X}$ \\
\hline 128 & TOLO2 & (C7H9O5) & I & & & & \\
\hline 129 & TOLOOH & (C7H10O5) & I & & & $\mathrm{X}$ & $\mathrm{X}$ \\
\hline 130 & TOLUENE & $(\mathrm{C} 7 \mathrm{H} 8)$ & I & $\mathrm{X}$ & & & \\
\hline 131 & XO2 & ( $\mathrm{HOCH} 2 \mathrm{COOCH} 3 \mathrm{CHOHCHO})$ & I & & & & \\
\hline 132 & $\mathrm{XOH}$ & $(\mathrm{C} 7 \mathrm{H} 10 \mathrm{O} 6)$ & I & & & & \\
\hline 133 & $\mathrm{XOOH}$ & ( $\mathrm{HOCH} 2 \mathrm{COOHCH} 3 \mathrm{CHOHCHO})$ & I & & & $X$ & $X$ \\
\hline 134 & XYLENE & (C8H10) & I & & & & \\
\hline 135 & XYLO2 & (C8H11O3) & I & & & & \\
\hline 136 & XYLOOH & (C8H12O3) & I & & & & \\
\hline
\end{tabular}


Table A1. Continued.

\begin{tabular}{|c|c|c|c|c|c|c|c|}
\hline No. & Aerosols & Formula & Solver & Emis. & LBC & Wet dep. & Dry dep. \\
\hline 1 & CB1 & (C), hydrophobic BC & I & $X$ & & $\mathrm{X}$ & \\
\hline 2 & CB2 & (C) hydrophilic BC & I & $X$ & & $X$ & \\
\hline 3 & $\mathrm{NH} 4$ & & I & & & & NH4 \\
\hline 4 & NH4NO3 & & I & & & & $\mathrm{X}$ \\
\hline 5 & OC1 & (C), hydrophobic OC & I & $X$ & & & $X$ \\
\hline 6 & OC2 & (C) hydrophilic OC & I & $X$ & & & $X$ \\
\hline 7 & DST01 & $(\mathrm{AlSiO} 5)$ & I & & & & \\
\hline 8 & DST02 & (AlSiO5) & I & & & & \\
\hline 9 & DST03 & (AlSiO5) & I & & & & \\
\hline 10 & DST04 & (AlSiO5) & I & & & & \\
\hline 11 & $\mathrm{SO} 4$ & & I & & & & $X$ \\
\hline 12 & SOAB & $(\mathrm{C} 6 \mathrm{H} 7 \mathrm{O} 3)$ & I & & & & $\mathrm{X}$ \\
\hline 13 & SOAI & (CH3C4H9O4) & I & & & & $\mathrm{X}$ \\
\hline 14 & SOAM & $(\mathrm{C} 10 \mathrm{H} 16 \mathrm{O} 4)$ & I & & & & $X$ \\
\hline 15 & SOAT & (C7H9O3) & I & & & & $X$ \\
\hline 16 & SOAX & (C8H11O3) & I & & & & $\mathrm{X}$ \\
\hline 17 & SSLT01 & $(\mathrm{NaCl})$ & I & & & & \\
\hline 18 & SSLT02 & $(\mathrm{NaCl})$ & I & & & & \\
\hline 19 & SSLT03 & $(\mathrm{NaCl})$ & I & & & & \\
\hline 20 & SSLT04 & $(\mathrm{NaCl})$ & $\mathrm{I}$ & & & & \\
\hline No. & Artificial tracers & Formula & Solver & Emis. & LBC & Wet dep. & Dry dep. \\
\hline 1 & $\mathrm{AOA}_{\mathrm{NH}}$ & $(\mathrm{H})$ & $\mathrm{E}$ & & & & \\
\hline 2 & $\mathrm{CO}_{25}$ & $(\mathrm{CO})$ & $\mathrm{E}$ & $X$ & & & \\
\hline 3 & $\mathrm{CO}_{50}$ & $(\mathrm{CO})$ & $\mathrm{E}$ & $X$ & & & \\
\hline 4 & E90 & $(\mathrm{CO})$ & $\mathrm{E}$ & $X$ & & & \\
\hline 5 & $\mathrm{E} 90_{\mathrm{NH}}$ & $(\mathrm{CO})$ & $\mathrm{E}$ & $X$ & & & \\
\hline 6 & $\mathrm{E} 90_{\mathrm{SH}}$ & $(\mathrm{CO})$ & $\mathrm{E}$ & $X$ & & & \\
\hline 7 & $\mathrm{NH}_{5}$ & $(\mathrm{H})$ & $\mathrm{E}$ & & & & \\
\hline 8 & $\mathrm{NH}_{50}$ & (H) & $\mathrm{E}$ & & & & \\
\hline 9 & $\mathrm{NH}_{50} W$ & $(\mathrm{H})$ & $\mathrm{E}$ & & & $\mathrm{X}$ & \\
\hline 10 & $\mathrm{O} 3 \mathrm{~S}$ & (O3) & $\mathrm{E}$ & & & & \\
\hline 11 & SF6em & (SF6) & $\mathrm{E}$ & $\mathrm{X}$ & & & \\
\hline 12 & $\mathrm{SO} 2 \mathrm{t}$ & (SO2) & $\mathrm{E}$ & & & $X$ & \\
\hline 13 & $\mathrm{ST}_{80} 5$ & $(\mathrm{H})$ & $\mathrm{E}$ & & & & \\
\hline
\end{tabular}


Table A2. Chemical reactions in CAM4-chem.

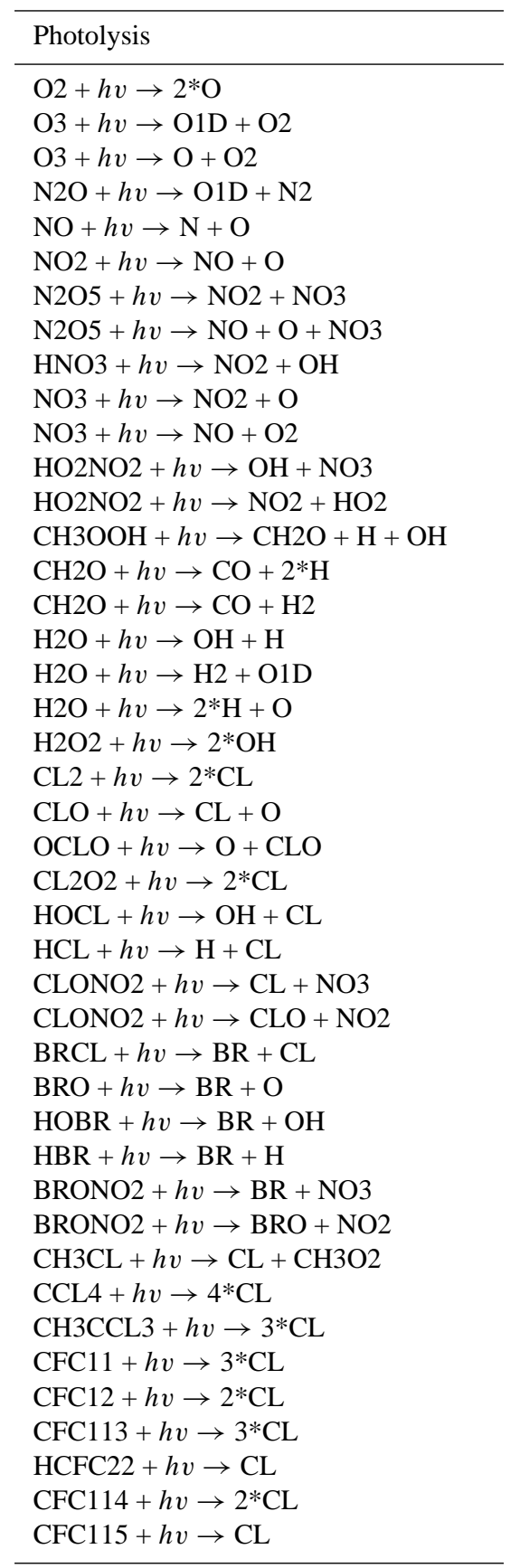


Table A2. Continued.

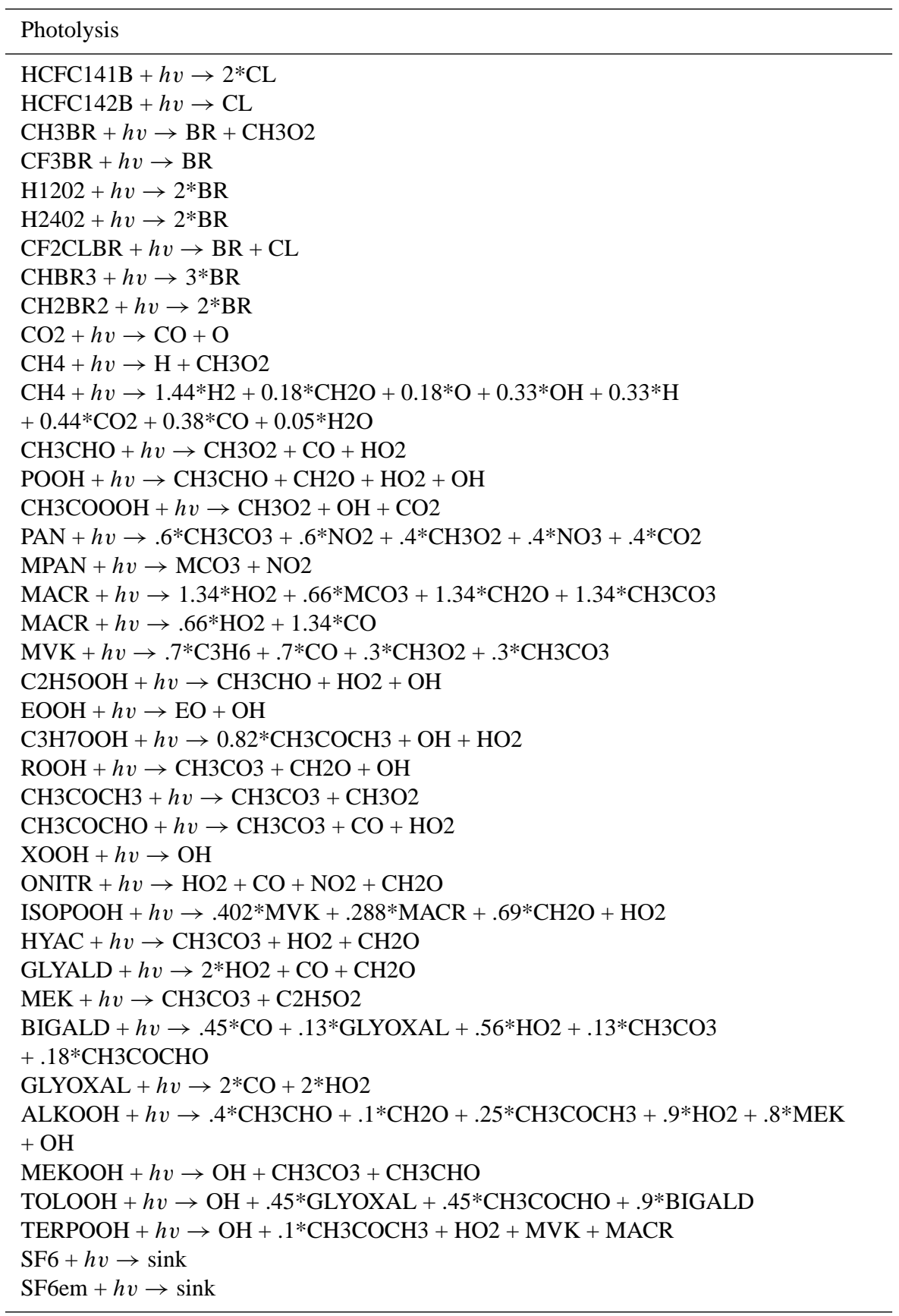


Table A2. Continued.

\begin{tabular}{|c|c|}
\hline Odd oxygen reactions & Rate \\
\hline $\mathrm{O}+\mathrm{O} 2+\mathrm{M} \rightarrow \mathrm{O} 3+\mathrm{M}$ & $6 . \mathrm{E}-34 *(300 / \mathrm{T}) * * 2.4$ \\
\hline $\mathrm{O}+\mathrm{O} 3 \rightarrow 2 * \mathrm{O} 2$ & $8.00 \mathrm{E}-12 * \exp (-2060 . / \mathrm{t})$ \\
\hline $\mathrm{O}+\mathrm{O}+\mathrm{M} \rightarrow \mathrm{O} 2+\mathrm{M}$ & $2.76 \mathrm{E}-34 * \exp (720 . / \mathrm{t})$ \\
\hline \multicolumn{2}{|l|}{ Odd oxygen reactions (O1D only) } \\
\hline $\mathrm{O} 1 \mathrm{D}+\mathrm{N} 2 \rightarrow \mathrm{O}+\mathrm{N} 2$ & $2.15 \mathrm{E}-11 * \exp (110 . / \mathrm{t})$ \\
\hline $\mathrm{O} 1 \mathrm{D}+\mathrm{O} 2 \rightarrow \mathrm{O}+\mathrm{O} 2$ & $3.30 \mathrm{E}-11 * \exp (55 . / \mathrm{t})$ \\
\hline $\mathrm{O} 1 \mathrm{D}+\mathrm{H} 2 \mathrm{O} \rightarrow 2 * \mathrm{OH}$ & $1.63 \mathrm{E}-10 * \exp (60 . / \mathrm{t})$ \\
\hline $\mathrm{O} 1 \mathrm{D}+\mathrm{N} 2 \mathrm{O} \rightarrow 2 * \mathrm{NO}$ & $7.25 \mathrm{E}-11 * \exp (20 . / \mathrm{t})$ \\
\hline $\mathrm{O} 1 \mathrm{D}+\mathrm{N} 2 \mathrm{O} \rightarrow \mathrm{N} 2+\mathrm{O} 2$ & $4.63 \mathrm{E}-11 * \exp (20 . / \mathrm{t})$ \\
\hline $\mathrm{O} 1 \mathrm{D}+\mathrm{O} 3 \rightarrow \mathrm{O} 2+\mathrm{O} 2$ & $1.20 \mathrm{E}-10$ \\
\hline $\mathrm{O} 1 \mathrm{D}+\mathrm{CFC} 11 \rightarrow 3 * \mathrm{CL}$ & $2.02 \mathrm{E}-10$ \\
\hline $\mathrm{O} 1 \mathrm{D}+\mathrm{CFC} 12 \rightarrow 2 * \mathrm{CL}$ & $1.20 \mathrm{E}-10$ \\
\hline $\mathrm{O} 1 \mathrm{D}+\mathrm{CFC} 113 \rightarrow 3 * \mathrm{CL}$ & $1.50 \mathrm{E}-10$ \\
\hline $\mathrm{O} 1 \mathrm{D}+\mathrm{CFC} 114 \rightarrow 2 * \mathrm{CL}$ & $9.75 \mathrm{E}-11$ \\
\hline $\mathrm{O} 1 \mathrm{D}+\mathrm{CFC} 115 \rightarrow \mathrm{CL}$ & $1.50 \mathrm{E}-11$ \\
\hline $\mathrm{O} 1 \mathrm{D}+\mathrm{HCFC} 22 \rightarrow \mathrm{CL}$ & $7.20 \mathrm{E}-11$ \\
\hline $\mathrm{O} 1 \mathrm{D}+\mathrm{HCFC} 141 \mathrm{~B} \rightarrow 2 * \mathrm{CL}$ & $1.79 \mathrm{E}-10$ \\
\hline $\mathrm{O} 1 \mathrm{D}+\mathrm{HCFC} 142 \mathrm{~B} \rightarrow \mathrm{CL}$ & $1.63 \mathrm{E}-10$ \\
\hline $\mathrm{O} 1 \mathrm{D}+\mathrm{CCL} 4 \rightarrow 4 * \mathrm{CL}$ & $2.84 \mathrm{E}-10$ \\
\hline $\mathrm{O} 1 \mathrm{D}+\mathrm{CH} 3 \mathrm{BR} \rightarrow \mathrm{BR}$ & $1.67 \mathrm{E}-10$ \\
\hline $\mathrm{O} 1 \mathrm{D}+\mathrm{CF} 2 \mathrm{CLBR} \rightarrow \mathrm{CL}+\mathrm{BR}$ & $9.60 \mathrm{E}-11$ \\
\hline $\mathrm{O} 1 \mathrm{D}+\mathrm{CF} 3 \mathrm{BR} \rightarrow \mathrm{BR}$ & $4.10 \mathrm{E}-11$ \\
\hline $\mathrm{O} 1 \mathrm{D}+\mathrm{H} 1202 \rightarrow 2 * \mathrm{BR}$ & $1.01 \mathrm{E}-10$ \\
\hline $\mathrm{O} 1 \mathrm{D}+\mathrm{H} 2402 \rightarrow 2 * \mathrm{BR}$ & $1.20 \mathrm{E}-10$ \\
\hline $\mathrm{O} 1 \mathrm{D}+\mathrm{CHBR} 3 \rightarrow 3 * \mathrm{BR}$ & $4.49 \mathrm{E}-10$ \\
\hline $\mathrm{O} 1 \mathrm{D}+\mathrm{CH} 2 \mathrm{BR} 2 \rightarrow 2 * \mathrm{BR}$ & $2.57 \mathrm{E}-10$ \\
\hline $\mathrm{O} 1 \mathrm{D}+\mathrm{CH} 4 \rightarrow \mathrm{CH} 3 \mathrm{O} 2+\mathrm{OH}$ & $1.31 \mathrm{E}-10$ \\
\hline $\mathrm{O} 1 \mathrm{D}+\mathrm{CH} 4 \rightarrow \mathrm{CH} 2 \mathrm{O}+\mathrm{H}+\mathrm{HO} 2$ & $3.50 \mathrm{E}-11$ \\
\hline $\mathrm{O} 1 \mathrm{D}+\mathrm{CH} 4 \rightarrow \mathrm{CH} 2 \mathrm{O}+\mathrm{H} 2$ & $9.00 \mathrm{E}-12$ \\
\hline $\mathrm{O} 1 \mathrm{D}+\mathrm{H} 2 \rightarrow \mathrm{H}+\mathrm{OH}$ & $1.20 \mathrm{E}-10$ \\
\hline $\mathrm{O} 1 \mathrm{D}+\mathrm{HCL} \rightarrow \mathrm{CL}+\mathrm{OH}$ & $1.50 \mathrm{E}-10$ \\
\hline $\mathrm{O} 1 \mathrm{D}+\mathrm{HBR} \rightarrow \mathrm{BR}+\mathrm{OH}$ & $1.20 \mathrm{E}-10$ \\
\hline $\mathrm{O} 1 \mathrm{D}+\mathrm{HCN} \rightarrow \mathrm{OH}$ & $7.70 \mathrm{E}-11 * \exp (100 . / \mathrm{t})$ \\
\hline \multicolumn{2}{|l|}{ Odd hydrogen reactions } \\
\hline $\mathrm{H}+\mathrm{O} 2+\mathrm{M} \rightarrow \mathrm{HO} 2+\mathrm{M}$ & $\begin{array}{l}\mathrm{ko}=4.40 \mathrm{E}-32 *(300 / \mathrm{t}) * * 1.30 \\
\mathrm{ki}=7.50 \mathrm{E}-11 *(300 / \mathrm{t}) * *_{-}-0.20 \\
\mathrm{f}=0.60\end{array}$ \\
\hline $\mathrm{H}+\mathrm{O} 3 \rightarrow \mathrm{OH}+\mathrm{O} 2$ & $1.40 \mathrm{E}-10 * \exp (-470 . / \mathrm{t})$ \\
\hline $\mathrm{H}+\mathrm{HO} 2 \rightarrow 2 * \mathrm{OH}$ & $7.20 \mathrm{E}-11$ \\
\hline $\mathrm{H}+\mathrm{HO} 2 \rightarrow \mathrm{H} 2+\mathrm{O} 2$ & $6.90 \mathrm{E}-12$ \\
\hline $\mathrm{H}+\mathrm{HO} 2 \rightarrow \mathrm{H} 2 \mathrm{O}+\mathrm{O}$ & $1.60 \mathrm{E}-12$ \\
\hline $\mathrm{OH}+\mathrm{O} \rightarrow \mathrm{H}+\mathrm{O} 2$ & $1.80 \mathrm{E}-11 * \exp (180 . / \mathrm{t})$ \\
\hline $\mathrm{OH}+\mathrm{O} 3 \rightarrow \mathrm{HO} 2+\mathrm{O} 2$ & $1.70 \mathrm{E}-12 * \exp (-940 . / \mathrm{t})$ \\
\hline $\mathrm{OH}+\mathrm{HO} 2 \rightarrow \mathrm{H} 2 \mathrm{O}+\mathrm{O} 2$ & $4.80 \mathrm{E}-11 * \exp (250 . / \mathrm{t})$ \\
\hline $\mathrm{OH}+\mathrm{OH} \rightarrow \mathrm{H} 2 \mathrm{O}+\mathrm{O}$ & $1.80 \mathrm{E}-12$ \\
\hline \multirow[t]{3}{*}{$\mathrm{OH}+\mathrm{OH}+\mathrm{M} \rightarrow \mathrm{H} 2 \mathrm{O} 2+\mathrm{M}$} & $\mathrm{ko}=6.90 \mathrm{E}-31 *(300 / \mathrm{t}) * * 1.00$ \\
\hline & $\mathrm{ki}=2.60 \mathrm{E}-11$ \\
\hline & $\mathrm{f}=0.60$ \\
\hline
\end{tabular}


Table A2. Continued.

\begin{tabular}{|c|c|}
\hline \multicolumn{2}{|l|}{ Odd hydrogen reactions } \\
\hline $\mathrm{OH}+\mathrm{H} 2 \rightarrow \mathrm{H} 2 \mathrm{O}+\mathrm{H}$ & $2.80 \mathrm{E}-12 * \exp (-1800 . / \mathrm{t})$ \\
\hline $\mathrm{OH}+\mathrm{H} 2 \mathrm{O} 2 \rightarrow \mathrm{H} 2 \mathrm{O}+\mathrm{HO} 2$ & $1.80 \mathrm{E}-12$ \\
\hline $\mathrm{H} 2+\mathrm{O} \rightarrow \mathrm{OH}+\mathrm{H}$ & $1.60 \mathrm{E}-11 * \exp (-4570 . / \mathrm{t})$ \\
\hline $\mathrm{HO} 2+\mathrm{O} \rightarrow \mathrm{OH}+\mathrm{O} 2$ & $3.00 \mathrm{E}-11 * \exp (200 . / \mathrm{t})$ \\
\hline $\mathrm{HO} 2+\mathrm{O} 3 \rightarrow \mathrm{OH}+2 * \mathrm{O} 2$ & $1.00 \mathrm{E}-14 * \exp (-490 . / \mathrm{t})$ \\
\hline $\mathrm{HO} 2+\mathrm{HO} 2 \rightarrow \mathrm{H} 2 \mathrm{O} 2+\mathrm{O} 2$ & $3.0 \mathrm{E}-13 * \exp (460 / \mathrm{t})$ \\
\hline & $+2.1 \mathrm{E}-33 *[\mathrm{M}] * \exp (920 / \mathrm{t}))$ \\
\hline & $*(1+1.4 \mathrm{E}-21 *[\mathrm{H} 2 \mathrm{O}] \exp (2200 / \mathrm{t}))$ \\
\hline $\mathrm{H} 2 \mathrm{O} 2+\mathrm{O} \rightarrow \mathrm{OH}+\mathrm{HO} 2$ & $1.40 \mathrm{E}-12 * \exp (-2000 . / \mathrm{t})$ \\
\hline $\mathrm{HCN}+\mathrm{OH}+\mathrm{M} \rightarrow \mathrm{HO} 2+\mathrm{M}$ & $\mathrm{ko}=4.28 \mathrm{E}-33$ \\
\hline & $\begin{array}{l}\mathrm{ki}=9.30 \mathrm{E}-15 *(300 / \mathrm{t}) * *-4.42 \\
\mathrm{f}=0.80\end{array}$ \\
\hline $\mathrm{CH} 3 \mathrm{CN}+\mathrm{OH} \rightarrow \mathrm{HO} 2$ & $7.80 \mathrm{E}-13^{*} \exp (-1050 . / \mathrm{t})$ \\
\hline \multicolumn{2}{|l|}{ Odd nitrogen reactions } \\
\hline $\mathrm{N}+\mathrm{O} 2 \rightarrow \mathrm{NO}+\mathrm{O}$ & $1.50 \mathrm{E}-11 * \exp (-3600 . / \mathrm{t})$ \\
\hline $\mathrm{N}+\mathrm{NO} \rightarrow \mathrm{N} 2+\mathrm{O}$ & $2.10 \mathrm{E}-11 * \exp (100 . / \mathrm{t})$ \\
\hline $\mathrm{N}+\mathrm{NO} 2 \rightarrow \mathrm{N} 2 \mathrm{O}+\mathrm{O}$ & $2.90 \mathrm{E}-12 * \exp (220 . / \mathrm{t})$ \\
\hline $\mathrm{N}+\mathrm{NO} 2 \rightarrow 2 * \mathrm{NO}$ & $1.45 \mathrm{E}-12 * \exp (220 . / \mathrm{t})$ \\
\hline $\mathrm{N}+\mathrm{NO} 2 \rightarrow \mathrm{N} 2+\mathrm{O} 2$ & $1.45 \mathrm{E}-12 * \exp (220 . / \mathrm{t})$ \\
\hline $\mathrm{NO}+\mathrm{O}+\mathrm{M} \rightarrow \mathrm{NO} 2+\mathrm{M}$ & $\begin{array}{l}\mathrm{ko}=9.00 \mathrm{E}-32 *(300 / \mathrm{t}) * * 1.50 \\
\mathrm{ki}=3.00 \mathrm{E}-11 \\
\mathrm{f}=0.60\end{array}$ \\
\hline $\mathrm{NO}+\mathrm{HO} 2 \rightarrow \mathrm{NO} 2+\mathrm{OH}$ & $3.30 \mathrm{E}-12 * \exp (270 . / \mathrm{t})$ \\
\hline $\mathrm{NO}+\mathrm{O} 3 \rightarrow \mathrm{NO} 2+\mathrm{O} 2$ & $3.00 \mathrm{E}-12 * \exp (-1500 . / \mathrm{t})$ \\
\hline $\mathrm{NO} 2+\mathrm{O} \rightarrow \mathrm{NO}+\mathrm{O} 2$ & $5.10 \mathrm{E}-12 * \exp (210 . / \mathrm{t})$ \\
\hline $\mathrm{NO} 2+\mathrm{O}+\mathrm{M} \rightarrow \mathrm{NO} 3+\mathrm{M}$ & $\begin{array}{l}\mathrm{ko}=2.50 \mathrm{E}-31 *(300 / \mathrm{t}) * * 1.80 \\
\mathrm{ki}=2.20 \mathrm{E}-11 *(300 / \mathrm{t}) * * 0.70 \\
\mathrm{f}=0.60\end{array}$ \\
\hline $\mathrm{NO} 2+\mathrm{O} 3 \rightarrow \mathrm{NO} 3+\mathrm{O} 2$ & $1.20 \mathrm{E}-13^{*} \exp (-2450 . / \mathrm{t})$ \\
\hline $\mathrm{NO} 2+\mathrm{NO} 3+\mathrm{M} \rightarrow \mathrm{N} 2 \mathrm{O} 5+\mathrm{M}$ & $\begin{array}{l}\mathrm{ko}=2.00 \mathrm{E}-30 *(300 / \mathrm{t}) * * 4.40 \\
\mathrm{ki}=1.40 \mathrm{E}-12 *(300 / \mathrm{t}) * * 0.70 \\
\mathrm{f}=0.60\end{array}$ \\
\hline $\mathrm{N} 2 \mathrm{O} 5+\mathrm{M} \rightarrow \mathrm{NO} 2+\mathrm{NO} 3+\mathrm{M}$ & $\begin{array}{l}\mathrm{k}(\mathrm{NO} 2+\mathrm{NO} 3+\mathrm{M}) \\
* 3.704 \mathrm{E} 26 * \exp (-11000 . / \mathrm{t})\end{array}$ \\
\hline $\mathrm{NO} 2+\mathrm{OH}+\mathrm{M} \rightarrow \mathrm{HNO} 3+\mathrm{M}$ & $\begin{array}{l}\mathrm{ko}=1.80 \mathrm{E}-30 *(300 / \mathrm{t}) * * 3.00 \\
\mathrm{ki}=2.80 \mathrm{E}-11 \\
\mathrm{f}=0.60\end{array}$ \\
\hline $\mathrm{HNO} 3+\mathrm{OH} \rightarrow \mathrm{NO} 3+\mathrm{H} 2 \mathrm{O}$ & $\begin{array}{l}\mathrm{k} 0+\mathrm{k} 3[\mathrm{M}] /(1+\mathrm{k} 3[\mathrm{M}] / \mathrm{k} 2) \\
\mathrm{k} 0=2.4 \mathrm{E}-14^{*} \exp (460 / \mathrm{t}) \\
\mathrm{k} 2=2.7 \mathrm{E}-17 * \exp (2199 / \mathrm{t}) \\
\mathrm{k} 3=6.5 \mathrm{E}-34 * \exp (1335 / \mathrm{t})\end{array}$ \\
\hline $\mathrm{NO} 3+\mathrm{NO} \rightarrow 2 * \mathrm{NO} 2$ & $1.50 \mathrm{E}-11 * \exp (170 . / \mathrm{t})$ \\
\hline $\mathrm{NO} 3+\mathrm{O} \rightarrow \mathrm{NO} 2+\mathrm{O} 2$ & $1.00 \mathrm{E}-11$ \\
\hline $\mathrm{NO} 3+\mathrm{OH} \rightarrow \mathrm{HO} 2+\mathrm{NO} 2$ & $2.20 \mathrm{E}-11$ \\
\hline $\mathrm{NO} 3+\mathrm{HO} 2 \rightarrow \mathrm{OH}+\mathrm{NO} 2+\mathrm{O} 2$ & $3.50 \mathrm{E}-12$ \\
\hline $\mathrm{NO} 2+\mathrm{HO} 2+\mathrm{M} \rightarrow \mathrm{HO} 2 \mathrm{NO} 2+\mathrm{M}$ & $\begin{array}{l}\mathrm{ko}=2.00 \mathrm{E}-31 *(300 / \mathrm{t}) * * 3.40 \\
\mathrm{ki}=2.90 \mathrm{E}-12 *(300 / \mathrm{t}) * * 1.10 \\
\mathrm{f}=0.60\end{array}$ \\
\hline $\mathrm{HO} 2 \mathrm{NO} 2+\mathrm{OH} \rightarrow \mathrm{H} 2 \mathrm{O}+\mathrm{NO} 2+\mathrm{O} 2$ & $1.30 \mathrm{E}-12 * \exp (380 . / \mathrm{t})$ \\
\hline $\mathrm{HO} 2 \mathrm{NO} 2+\mathrm{M} \rightarrow \mathrm{HO} 2+\mathrm{NO} 2+\mathrm{M}$ & $\begin{array}{l}\mathrm{k}(\mathrm{NO} 2+\mathrm{HO} 2+\mathrm{M}) \\
* \exp (-10900 / \mathrm{t}) / 2.1 \mathrm{E}-27\end{array}$ \\
\hline
\end{tabular}


Table A2. Continued.

\begin{tabular}{|c|c|}
\hline \multicolumn{2}{|l|}{ Odd chlorine reactions } \\
\hline $\mathrm{CL}+\mathrm{O} 3 \rightarrow \mathrm{CLO}+\mathrm{O} 2$ & $2.30 \mathrm{E}-11 * \exp (-200 . / \mathrm{t})$ \\
\hline $\mathrm{CL}+\mathrm{H} 2 \rightarrow \mathrm{HCL}+\mathrm{H}$ & $3.05 \mathrm{E}-11 * \exp (-2270 . / \mathrm{t})$ \\
\hline $\mathrm{CL}+\mathrm{H} 2 \mathrm{O} 2 \rightarrow \mathrm{HCL}+\mathrm{HO} 2$ & $1.10 \mathrm{E}-11 * \exp (-980 . / \mathrm{t})$ \\
\hline $\mathrm{CL}+\mathrm{HO} 2 \rightarrow \mathrm{HCL}+\mathrm{O} 2$ & $1.40 \mathrm{E}-11 * \exp (270 . / \mathrm{t})$ \\
\hline $\mathrm{CL}+\mathrm{HO} 2 \rightarrow \mathrm{OH}+\mathrm{CLO}$ & $3.60 \mathrm{E}-11 * \exp (-375 . / \mathrm{t})$ \\
\hline $\mathrm{CL}+\mathrm{CH} 2 \mathrm{O} \rightarrow \mathrm{HCL}+\mathrm{HO} 2+\mathrm{CO}$ & $8.10 \mathrm{E}-11 * \exp (-30 . / \mathrm{t})$ \\
\hline $\mathrm{CL}+\mathrm{CH} 4 \rightarrow \mathrm{CH} 3 \mathrm{O} 2+\mathrm{HCL}$ & $7.30 \mathrm{E}-12 * \exp (-1280 . / \mathrm{t})$ \\
\hline $\mathrm{CLO}+\mathrm{O} \rightarrow \mathrm{CL}+\mathrm{O} 2$ & $2.80 \mathrm{E}-11 * \exp (85 . / \mathrm{t})$ \\
\hline $\mathrm{CLO}+\mathrm{OH} \rightarrow \mathrm{CL}+\mathrm{HO} 2$ & $7.40 \mathrm{E}-12 * \exp (270 . / \mathrm{t})$ \\
\hline $\mathrm{CLO}+\mathrm{OH} \rightarrow \mathrm{HCL}+\mathrm{O} 2$ & $6.00 \mathrm{E}-13 * \exp (230 . / \mathrm{t})$ \\
\hline $\mathrm{CLO}+\mathrm{HO} 2 \rightarrow \mathrm{O} 2+\mathrm{HOCL}$ & $2.60 \mathrm{E}-12 * \exp (290 . / \mathrm{t})$ \\
\hline $\mathrm{CLO}+\mathrm{CH} 3 \mathrm{O} 2 \rightarrow \mathrm{CL}+\mathrm{HO} 2+\mathrm{CH} 2 \mathrm{O}$ & $3.30 \mathrm{E}-12 * \exp (-115 . / \mathrm{t})$ \\
\hline $\mathrm{CLO}+\mathrm{NO} \rightarrow \mathrm{NO} 2+\mathrm{CL}$ & $6.40 \mathrm{E}-12 * \exp (290 . / \mathrm{t})$ \\
\hline \multirow[t]{2}{*}{$\mathrm{CLO}+\mathrm{NO} 2+\mathrm{M} \rightarrow \mathrm{CLONO} 2+\mathrm{M}$} & $\mathrm{ko}=1.80 \mathrm{E}-31 *(300 / \mathrm{t}) * * 3.40$ \\
\hline & $\begin{array}{l}\mathrm{ki}=1.50 \mathrm{E}-11 *(300 / \mathrm{t}) * * 1.90 \\
\mathrm{f}=0.60\end{array}$ \\
\hline $\mathrm{CLO}+\mathrm{CLO} \rightarrow 2 * \mathrm{CL}+\mathrm{O} 2$ & $3.00 \mathrm{E}-11 * \exp (-2450 . / \mathrm{t})$ \\
\hline $\mathrm{CLO}+\mathrm{CLO} \rightarrow \mathrm{CL} 2+\mathrm{O} 2$ & $1.00 \mathrm{E}-12 * \exp (-1590 . / \mathrm{t})$ \\
\hline $\mathrm{CLO}+\mathrm{CLO} \rightarrow \mathrm{CL}+\mathrm{OCLO}$ & $3.50 \mathrm{E}-13 * \exp (-1370 . / \mathrm{t})$ \\
\hline \multirow[t]{2}{*}{$\mathrm{CLO}+\mathrm{CLO}+\mathrm{M} \rightarrow \mathrm{CL} 2 \mathrm{O} 2+\mathrm{M}$} & $\mathrm{ko}=1.60 \mathrm{E}-32 *(300 / \mathrm{t}) * * 4.50$ \\
\hline & $\begin{array}{l}\mathrm{ki}=3.00 \mathrm{E}-12 *(300 / \mathrm{t}) * 2.00 \\
\mathrm{f}=0.60\end{array}$ \\
\hline $\mathrm{CL} 2 \mathrm{O} 2+\mathrm{M} \rightarrow \mathrm{CLO}+\mathrm{CLO}+\mathrm{M}$ & $\mathrm{k}(\mathrm{CLO}+\mathrm{CLO}+\mathrm{M}) /(1.72 \mathrm{E}-27 * \exp (8649 . / \mathrm{t}))$ \\
\hline $\mathrm{HCL}+\mathrm{OH} \rightarrow \mathrm{H} 2 \mathrm{O}+\mathrm{CL}$ & $1.80 \mathrm{E}-12 * \exp (-250 . / \mathrm{t})$ \\
\hline $\mathrm{HCL}+\mathrm{O} \rightarrow \mathrm{CL}+\mathrm{OH}$ & $1.00 \mathrm{E}-11 * \exp (-3300 . / \mathrm{t})$ \\
\hline $\mathrm{HOCL}+\mathrm{O} \rightarrow \mathrm{CLO}+\mathrm{OH}$ & $1.70 \mathrm{E}-13$ \\
\hline $\mathrm{HOCL}+\mathrm{CL} \rightarrow \mathrm{HCL}+\mathrm{CLO}$ & $3.40 \mathrm{E}-12 * \exp (-130 . / \mathrm{t})$ \\
\hline $\mathrm{HOCL}+\mathrm{OH} \rightarrow \mathrm{H} 2 \mathrm{O}+\mathrm{CLO}$ & $3.00 \mathrm{E}-12 * \exp (-500 . / \mathrm{t})$ \\
\hline $\mathrm{CLONO} 2+\mathrm{O} \rightarrow \mathrm{CLO}+\mathrm{NO} 3$ & $3.60 \mathrm{E}-12 * \exp (-840 . / \mathrm{t})$ \\
\hline $\mathrm{CLONO} 2+\mathrm{OH} \rightarrow \mathrm{HOCL}+\mathrm{NO} 3$ & $1.20 \mathrm{E}-12 * \exp (-330 . / \mathrm{t})$ \\
\hline $\mathrm{CLONO} 2+\mathrm{CL} \rightarrow \mathrm{CL} 2+\mathrm{NO} 3$ & $6.50 \mathrm{E}-12 * \exp (135 . / \mathrm{t})$ \\
\hline \multicolumn{2}{|l|}{ Odd bromine reactions } \\
\hline $\mathrm{BR}+\mathrm{O} 3 \rightarrow \mathrm{BRO}+\mathrm{O} 2$ & $1.60 \mathrm{E}-11 * \exp (-780 . / \mathrm{t})$ \\
\hline $\mathrm{BR}+\mathrm{HO} 2 \rightarrow \mathrm{HBR}+\mathrm{O} 2$ & $4.80 \mathrm{E}-12 * \exp (-310 . / \mathrm{t})$ \\
\hline $\mathrm{BR}+\mathrm{CH} 2 \mathrm{O} \rightarrow \mathrm{HBR}+\mathrm{HO} 2+\mathrm{CO}$ & $1.70 \mathrm{E}-11 * \exp (-800 . / \mathrm{t})$ \\
\hline $\mathrm{BRO}+\mathrm{O} \rightarrow \mathrm{BR}+\mathrm{O} 2$ & $1.90 \mathrm{E}-11 * \exp (230 . / \mathrm{t})$ \\
\hline $\mathrm{BRO}+\mathrm{OH} \rightarrow \mathrm{BR}+\mathrm{HO} 2$ & $1.70 \mathrm{E}-11 * \exp (250 . / \mathrm{t})$ \\
\hline $\mathrm{BRO}+\mathrm{HO} 2 \rightarrow \mathrm{HOBR}+\mathrm{O} 2$ & $4.50 \mathrm{E}-12 * \exp (460 . / \mathrm{t})$ \\
\hline $\mathrm{BRO}+\mathrm{NO} \rightarrow \mathrm{BR}+\mathrm{NO} 2$ & $8.80 \mathrm{E}-12 * \exp (260 . / \mathrm{t})$ \\
\hline \multirow[t]{2}{*}{$\mathrm{BRO}+\mathrm{NO} 2+\mathrm{M} \rightarrow \mathrm{BRONO} 2+\mathrm{M}$} & $\mathrm{ko}=5.20 \mathrm{E}-31 *(300 / \mathrm{t}) * * 3.20$ \\
\hline & $\begin{array}{l}\mathrm{ki}=6.90 \mathrm{E}-12 *(300 / \mathrm{t}) * * 2.90 \\
\mathrm{f}=0.60\end{array}$ \\
\hline $\mathrm{BRO}+\mathrm{CLO} \rightarrow \mathrm{BR}+\mathrm{OCLO}$ & $9.50 \mathrm{E}-13 * \exp (550 . / \mathrm{t})$ \\
\hline $\mathrm{BRO}+\mathrm{CLO} \rightarrow \mathrm{BR}+\mathrm{CL}+\mathrm{O} 2$ & $2.30 \mathrm{E}-12 * \exp (260 . / \mathrm{t})$ \\
\hline $\mathrm{BRO}+\mathrm{CLO} \rightarrow \mathrm{BRCL}+\mathrm{O} 2$ & $4.10 \mathrm{E}-13 * \exp (290 . / \mathrm{t})$ \\
\hline $\mathrm{BRO}+\mathrm{BRO} \rightarrow 2 * \mathrm{BR}+\mathrm{O} 2$ & $1.50 \mathrm{E}-12 * \exp (230 . / \mathrm{t})$ \\
\hline $\mathrm{HBR}+\mathrm{OH} \rightarrow \mathrm{BR}+\mathrm{H} 2 \mathrm{O}$ & $5.50 \mathrm{E}-12 * \exp (200 . / \mathrm{t})$ \\
\hline $\mathrm{HBR}+\mathrm{O} \rightarrow \mathrm{BR}+\mathrm{OH}$ & $5.80 \mathrm{E}-12 * \exp (-1500 . / \mathrm{t})$ \\
\hline $\mathrm{HOBR}+\mathrm{O} \rightarrow \mathrm{BRO}+\mathrm{OH}$ & $1.20 \mathrm{E}-10 * \exp (-430 . / \mathrm{t})$ \\
\hline $\mathrm{BRONO} 2+\mathrm{O} \rightarrow \mathrm{BRO}+\mathrm{NO} 3$ & $1.90 \mathrm{E}-11 * \exp (215 . / \mathrm{t})$ \\
\hline
\end{tabular}


Table A2. Continued.

\begin{tabular}{|c|c|}
\hline Organic halogens reactions with $\mathrm{Cl}, \mathrm{OH}$ & Rate \\
\hline $\mathrm{CH} 3 \mathrm{CL}+\mathrm{CL} \rightarrow \mathrm{HO} 2+\mathrm{CO}+2 * \mathrm{HCL}$ & $2.17 \mathrm{E}-11 * \exp (-1130 . / \mathrm{t})$ \\
\hline $\mathrm{CH} 3 \mathrm{CL}+\mathrm{OH} \rightarrow \mathrm{CL}+\mathrm{H} 2 \mathrm{O}+\mathrm{HO} 2$ & $2.40 \mathrm{E}-12 * \exp (-1250 . / \mathrm{t})$ \\
\hline $\mathrm{CH} 3 \mathrm{CCL} 3+\mathrm{OH} \rightarrow \mathrm{H} 2 \mathrm{O}+3 * \mathrm{CL}$ & $1.64 \mathrm{E}-12 * \exp (-1520 . / \mathrm{t})$ \\
\hline $\mathrm{HCFC} 22+\mathrm{OH} \rightarrow \mathrm{H} 2 \mathrm{O}+\mathrm{CL}$ & $1.05 \mathrm{E}-12 * \exp (-1600 . / \mathrm{t})$ \\
\hline $\mathrm{CH} 3 \mathrm{BR}+\mathrm{OH} \rightarrow \mathrm{BR}+\mathrm{H} 2 \mathrm{O}+\mathrm{HO} 2$ & $2.35 \mathrm{E}-12 * \exp (-1300 . / \mathrm{t})$ \\
\hline $\mathrm{CH} 3 \mathrm{BR}+\mathrm{CL} \rightarrow \mathrm{HCL}+\mathrm{HO} 2+\mathrm{BR}$ & $1.40 \mathrm{E}-11 * \exp (-1030 . / \mathrm{t})$ \\
\hline $\mathrm{HCFC} 141 \mathrm{~B}+\mathrm{OH} \rightarrow 2 * \mathrm{CL}$ & $1.25 \mathrm{E}-12 * \exp (-1600 . / \mathrm{t})$ \\
\hline $\mathrm{HCFC} 142 \mathrm{~B}+\mathrm{OH} \rightarrow \mathrm{CL}$ & $1.30 \mathrm{E}-12 * \exp (-1770 . / \mathrm{t})$ \\
\hline $\mathrm{CH} 2 \mathrm{BR} 2+\mathrm{OH} \rightarrow 2 * \mathrm{BR}+\mathrm{H} 2 \mathrm{O}$ & $2.00 \mathrm{E}-12 * \exp (-840 . / \mathrm{t})$ \\
\hline $\mathrm{CHBR} 3+\mathrm{OH} \rightarrow 3 * \mathrm{BR}$ & $1.35 \mathrm{E}-12 * \exp (-600 . / \mathrm{t})$ \\
\hline $\mathrm{CH} 2 \mathrm{BR} 2+\mathrm{CL} \rightarrow 2 * \mathrm{BR}+\mathrm{HCL}$ & $6.30 \mathrm{E}-12 * \exp (-800 . / \mathrm{t})$ \\
\hline $\mathrm{CHBR} 3+\mathrm{CL} \rightarrow 3 * \mathrm{BR}+\mathrm{HCL}$ & $4.85 \mathrm{E}-12 * \exp (-850 . / \mathrm{t})$ \\
\hline \multicolumn{2}{|l|}{$\mathrm{C}-1$ degradation (Methane, $\mathrm{CO}, \mathrm{CH} 2 \mathrm{O}$ and derivatives) } \\
\hline $\mathrm{CH} 4+\mathrm{OH} \rightarrow \mathrm{CH} 3 \mathrm{O} 2+\mathrm{H} 2 \mathrm{O}$ & $2.45 \mathrm{E}-12 * \exp (-1775 . / \mathrm{t})$ \\
\hline \multirow[t]{4}{*}{$\mathrm{CO}+\mathrm{OH} \rightarrow \mathrm{CO} 2+\mathrm{H}$} & $\mathrm{ki}=2.1 \mathrm{E} 09 *(\mathrm{t} / 300) * * 6.1$ \\
\hline & $\mathrm{ko}=1.5 \mathrm{E}-13 *(\mathrm{t} / 300) * * 0.6$ \\
\hline & rate $=\mathrm{ko} /(1+\mathrm{ko} /(\mathrm{ki} / \mathrm{M}))$ \\
\hline & $* 0.6 * *(1 /(1+\log 10(\mathrm{ko} /(\mathrm{ki} / \mathrm{M}) * * 2)))$ \\
\hline \multirow[t]{3}{*}{$\mathrm{CO}+\mathrm{OH}+\mathrm{M} \rightarrow \mathrm{CO} 2+\mathrm{HO} 2+\mathrm{M}$} & $\mathrm{ko}=5.90 \mathrm{E}-33 *(300 / \mathrm{t}) * * 1.40$ \\
\hline & $\mathrm{ki}=1.10 \mathrm{E}-12 *(300 / \mathrm{t}) * *-1.30$ \\
\hline & $f=0.60$ \\
\hline $\mathrm{CH} 2 \mathrm{O}+\mathrm{NO} 3 \rightarrow \mathrm{CO}+\mathrm{HO} 2+\mathrm{HNO} 3$ & $6.00 \mathrm{E}-13 * \exp (-2058 . / \mathrm{t})$ \\
\hline $\mathrm{CH} 2 \mathrm{O}+\mathrm{OH} \rightarrow \mathrm{CO}+\mathrm{H} 2 \mathrm{O}+\mathrm{H}$ & $5.50 \mathrm{E}-12 * \exp (125 . / \mathrm{t})$ \\
\hline $\mathrm{CH} 2 \mathrm{O}+\mathrm{O} \rightarrow \mathrm{HO} 2+\mathrm{OH}+\mathrm{CO}$ & $3.40 \mathrm{E}-11 * \exp (-1600 . / \mathrm{t})$ \\
\hline $\mathrm{CH} 2 \mathrm{O}+\mathrm{HO} 2 \rightarrow \mathrm{HOCH} 2 \mathrm{OO}$ & $9.70 \mathrm{E}-15^{*} \exp (625 . / \mathrm{t})$ \\
\hline $\mathrm{CH} 3 \mathrm{O} 2+\mathrm{NO} \rightarrow \mathrm{CH} 2 \mathrm{O}+\mathrm{NO} 2+\mathrm{HO}_{2}$ & $2.80 \mathrm{E}-12 * \exp (300 . / \mathrm{t})$ \\
\hline $\mathrm{CH} 3 \mathrm{O} 2+\mathrm{HO} 2 \rightarrow \mathrm{CH} 3 \mathrm{OOH}+\mathrm{O} 2$ & $4.10 \mathrm{E}-13 * \exp (750 . / \mathrm{t})$ \\
\hline $\mathrm{CH} 3 \mathrm{O} 2+\mathrm{CH} 3 \mathrm{O} 2 \rightarrow 2 * \mathrm{CH} 2 \mathrm{O}+2 * \mathrm{HO} 2$ & $5.00 \mathrm{E}-13 * \exp (-424 . / \mathrm{t})$ \\
\hline $\mathrm{CH} 3 \mathrm{O} 2+\mathrm{CH} 3 \mathrm{O} 2 \rightarrow \mathrm{CH} 2 \mathrm{O}+\mathrm{CH} 3 \mathrm{OH}$ & $1.90 \mathrm{E}-14 * \exp (706 . / \mathrm{t})$ \\
\hline $\mathrm{CH} 3 \mathrm{OH}+\mathrm{OH} \rightarrow \mathrm{HO} 2+\mathrm{CH} 2 \mathrm{O}$ & $2.90 \mathrm{E}-12 * \exp (-345 . / \mathrm{t})$ \\
\hline $\mathrm{CH} 3 \mathrm{OOH}+\mathrm{OH} \rightarrow .7 * \mathrm{CH} 3 \mathrm{O} 2+.3 * \mathrm{OH}+.3 * \mathrm{CH} 2 \mathrm{O}+\mathrm{H} 2 \mathrm{O}$ & $3.80 \mathrm{E}-12 * \exp (200 . / \mathrm{t})$ \\
\hline $\mathrm{HCOOH}+\mathrm{OH} \rightarrow \mathrm{HO} 2+\mathrm{CO} 2+\mathrm{H} 2 \mathrm{O}$ & $4.50 \mathrm{E}-13$ \\
\hline $\mathrm{HOCH} 2 \mathrm{OO} \rightarrow \mathrm{CH} 2 \mathrm{O}+\mathrm{HO} 2$ & $2.40 \mathrm{E}+12 * \exp (-7000 . / \mathrm{t})$ \\
\hline $\mathrm{HOCH} 2 \mathrm{OO}+\mathrm{NO} \rightarrow \mathrm{HCOOH}+\mathrm{NO} 2+\mathrm{HO} 2$ & $2.60 \mathrm{E}-12 * \exp (265 . / \mathrm{t})$ \\
\hline $\mathrm{HOCH} 2 \mathrm{OO}+\mathrm{HO} 2 \rightarrow \mathrm{HCOOH}$ & $7.50 \mathrm{E}-13 * \exp (700 . / \mathrm{t})$ \\
\hline \multicolumn{2}{|l|}{ C-2 degradation } \\
\hline \multirow[t]{2}{*}{$\mathrm{C} 2 \mathrm{H} 2+\mathrm{CL}+\mathrm{M} \rightarrow \mathrm{CL}+\mathrm{M}$} & $\mathrm{ko}=5.20 \mathrm{E}-30 *(300 / \mathrm{t}) * * 2.40$ \\
\hline & $\begin{array}{l}\mathrm{ki}=2.20 \mathrm{E}-10 *(300 / \mathrm{t}) * * 0.70 \\
\mathrm{f}=0.60\end{array}$ \\
\hline \multirow[t]{3}{*}{$\mathrm{C} 2 \mathrm{H} 4+\mathrm{CL}+\mathrm{M} \rightarrow \mathrm{CL}+\mathrm{M}$} & $\mathrm{ko}=1.60 \mathrm{E}-29 *(300 / \mathrm{t}) * * 3.30$ \\
\hline & $\mathrm{ki}=3.10 \mathrm{E}-10 *(300 / \mathrm{t})$ \\
\hline & $\mathrm{f}=0.60$ \\
\hline $\mathrm{C} 2 \mathrm{H} 6+\mathrm{CL} \rightarrow \mathrm{HCL}+\mathrm{C} 2 \mathrm{H} 5 \mathrm{O} 2$ & $7.20 \mathrm{E}-11 * \exp (-70 . / \mathrm{t})$ \\
\hline $\mathrm{C} 2 \mathrm{H} 2+\mathrm{OH}+\mathrm{M} \rightarrow .65 * \mathrm{GLYOXAL}+.65 * \mathrm{OH}+.35 * \mathrm{HCOOH}+.35 * \mathrm{HO} 2$ & $\mathrm{ko}=5.50 \mathrm{E}-30$ \\
\hline$+.35^{*} \mathrm{CO}+\mathrm{M}$ & $\mathrm{ki}=8.30 \mathrm{E}-13 *(300 / \mathrm{t}) * *-2.00$ \\
\hline $\mathrm{C} 2 \mathrm{H} 6+\mathrm{OH} \rightarrow \mathrm{C} 2 \mathrm{H} 5 \mathrm{O} 2+\mathrm{H} 2 \mathrm{O}$ & $7.66 \mathrm{E}-12 * \exp (-1020 . / \mathrm{t})$ \\
\hline \multirow[t]{3}{*}{$\mathrm{C} 2 \mathrm{H} 4+\mathrm{OH}+\mathrm{M} \rightarrow \mathrm{EO} 2+\mathrm{M}$} & $\mathrm{ko}=8.60 \mathrm{E}-29 *(300 / \mathrm{t}) * * 3.10$ \\
\hline & $\mathrm{ki}=9.00 \mathrm{E}-12 *(300 / \mathrm{t}) * * 0.85$ \\
\hline & $\mathrm{f}=0.48$ \\
\hline
\end{tabular}


Table A2. Continued.

\begin{tabular}{|c|c|}
\hline \multicolumn{2}{|l|}{ C-2 degradation } \\
\hline $\mathrm{EO} 2+\mathrm{NO} \rightarrow 0.5 * \mathrm{CH} 2 \mathrm{O}+0.25 * \mathrm{HO} 2+0.75 * \mathrm{EO}+\mathrm{NO} 2$ & $4.20 \mathrm{E}-12 * \exp (180 . / \mathrm{t})$ \\
\hline $\mathrm{EO} 2+\mathrm{HO} 2 \rightarrow \mathrm{EOOH}$ & $7.50 \mathrm{E}-13 * \exp (700 . / \mathrm{t})$ \\
\hline $\mathrm{EO}+\mathrm{O} 2 \rightarrow \mathrm{GLYALD}+\mathrm{HO} 2$ & $1.00 \mathrm{E}-14$ \\
\hline $\mathrm{EO} \rightarrow 2 * \mathrm{CH} 2 \mathrm{O}+\mathrm{HO} 2$ & $1.60 \mathrm{E}+11 * \exp (-4150 . / \mathrm{t})$ \\
\hline $\mathrm{C} 2 \mathrm{H} 4+\mathrm{O} 3 \rightarrow \mathrm{CH} 2 \mathrm{O}+.12 * \mathrm{HO} 2+.5 * \mathrm{CO}+.12 * \mathrm{OH}+.5 * \mathrm{HCOOH}$ & $1.20 \mathrm{E}-14 * \exp (-2630 . / \mathrm{t})$ \\
\hline $\mathrm{CH} 3 \mathrm{COOH}+\mathrm{OH} \rightarrow \mathrm{CH} 3 \mathrm{O} 2+\mathrm{CO} 2+\mathrm{H} 2 \mathrm{O}$ & $7.00 \mathrm{E}-13$ \\
\hline $\mathrm{C} 2 \mathrm{H} 5 \mathrm{O} 2+\mathrm{NO} \rightarrow \mathrm{CH} 3 \mathrm{CHO}+\mathrm{HO} 2+\mathrm{NO} 2$ & $2.60 \mathrm{E}-12 * \exp (365 . / \mathrm{t})$ \\
\hline $\mathrm{C} 2 \mathrm{H} 5 \mathrm{O} 2+\mathrm{HO} 2 \rightarrow \mathrm{C} 2 \mathrm{H} 5 \mathrm{OOH}+\mathrm{O} 2$ & $7.50 \mathrm{E}-13 * \exp (700 . / \mathrm{t})$ \\
\hline $\begin{array}{l}\mathrm{C} 2 \mathrm{H} 5 \mathrm{O} 2+\mathrm{CH} 3 \mathrm{O} 2 \rightarrow .7 * \mathrm{CH} 2 \mathrm{O}+.8 * \mathrm{CH} 3 \mathrm{CHO}+\mathrm{HO} 2+.3 * \mathrm{CH} 3 \mathrm{OH} \\
+.2 * \mathrm{C} 2 \mathrm{H} 5 \mathrm{OH}\end{array}$ & $2.00 \mathrm{E}-13$ \\
\hline $\mathrm{C} 2 \mathrm{H} 5 \mathrm{O} 2+\mathrm{C} 2 \mathrm{H} 5 \mathrm{O} 2 \rightarrow 1.6 * \mathrm{CH} 3 \mathrm{CHO}+1.2 * \mathrm{HO} 2+.4 * \mathrm{C} 2 \mathrm{H} 5 \mathrm{OH}$ & $6.80 \mathrm{E}-14$ \\
\hline $\mathrm{C} 2 \mathrm{H} 5 \mathrm{OOH}+\mathrm{OH} \rightarrow .5 * \mathrm{C} 2 \mathrm{H} 5 \mathrm{O} 2+.5 * \mathrm{CH} 3 \mathrm{CHO}+.5 * \mathrm{OH}$ & $3.80 \mathrm{E}-12 * \exp (200 . / \mathrm{t})$ \\
\hline $\mathrm{CH} 3 \mathrm{CHO}+\mathrm{OH} \rightarrow \mathrm{CH} 3 \mathrm{CO} 3+\mathrm{H} 2 \mathrm{O}$ & $4.63 \mathrm{E}-12 * \exp (350 . / \mathrm{t})$ \\
\hline $\mathrm{CH} 3 \mathrm{CHO}+\mathrm{NO} 3 \rightarrow \mathrm{CH} 3 \mathrm{CO} 3+\mathrm{HNO} 3$ & $1.40 \mathrm{E}-12 * \exp (-1900 . / \mathrm{t})$ \\
\hline $\mathrm{CH} 3 \mathrm{CO} 3+\mathrm{NO} \rightarrow \mathrm{CH} 3 \mathrm{O} 2+\mathrm{CO} 2+\mathrm{NO} 2$ & $8.10 \mathrm{E}-12 * \exp (270 . / \mathrm{t})$ \\
\hline $\mathrm{CH} 3 \mathrm{CO} 3+\mathrm{NO} 2+\mathrm{M} \rightarrow \mathrm{PAN}+\mathrm{M}$ & $\begin{array}{l}\mathrm{ko}=9.70 \mathrm{E}-29 *(300 / \mathrm{t}) * * 5.60 \\
\mathrm{ki}=9.30 \mathrm{E}-12 *(300 / \mathrm{t})^{* * 1.50} \\
\mathrm{f}=0.60\end{array}$ \\
\hline $\mathrm{CH} 3 \mathrm{CO} 3+\mathrm{HO} 2 \rightarrow .75^{*} \mathrm{CH} 3 \mathrm{COOOH}+.25 * \mathrm{CH} 3 \mathrm{COOH}+.25 * \mathrm{O} 3$ & $4.30 \mathrm{E}-13 * \exp (1040 . / \mathrm{t})$ \\
\hline $\begin{array}{l}\mathrm{CH} 3 \mathrm{CO} 3+\mathrm{CH} 3 \mathrm{O} 2 \rightarrow .9 * \mathrm{CH} 3 \mathrm{O} 2+\mathrm{CH} 2 \mathrm{O}+.9 * \mathrm{HO} 2+.9 * \mathrm{CO} 2 \\
+.1 * \mathrm{CH} 3 \mathrm{COOH}\end{array}$ & $2.00 \mathrm{E}-12 * \exp (500 . / \mathrm{t})$ \\
\hline $\mathrm{CH} 3 \mathrm{CO} 3+\mathrm{CH} 3 \mathrm{CO} 3 \rightarrow 2 * \mathrm{CH} 3 \mathrm{O} 2+2 * \mathrm{CO} 2$ & $2.50 \mathrm{E}-12 * \exp (500 . / \mathrm{t})$ \\
\hline $\mathrm{CH} 3 \mathrm{COOOH}+\mathrm{OH} \rightarrow .5 * \mathrm{CH} 3 \mathrm{CO} 3+.5 * \mathrm{CH} 2 \mathrm{O}+.5 * \mathrm{CO} 2+\mathrm{H} 2 \mathrm{O}$ & $1.00 \mathrm{E}-12$ \\
\hline $\mathrm{GLYALD}+\mathrm{OH} \rightarrow \mathrm{HO} 2+.2 * \mathrm{GLYOXAL}+.8 * \mathrm{CH} 2 \mathrm{O}+.8 * \mathrm{CO} 2$ & $1.00 \mathrm{E}-11$ \\
\hline $\mathrm{GLYOXAL}+\mathrm{OH} \rightarrow \mathrm{HO} 2+\mathrm{CO}+\mathrm{CO} 2$ & $1.15 \mathrm{E}-11$ \\
\hline $\mathrm{C} 2 \mathrm{H} 5 \mathrm{OH}+\mathrm{OH} \rightarrow \mathrm{HO} 2+\mathrm{CH} 3 \mathrm{CHO}$ & $6.90 \mathrm{E}-12 * \exp (-230 . / \mathrm{t})$ \\
\hline $\mathrm{PAN}+\mathrm{M} \rightarrow \mathrm{CH} 3 \mathrm{CO} 3+\mathrm{NO} 2+\mathrm{M}$ & $\begin{array}{l}\mathrm{k}(\mathrm{CH} 3 \mathrm{CO} 3+\mathrm{NO} 2+\mathrm{M}) \\
* 1.111 \mathrm{E} 28 * \exp (-14000 / \mathrm{t})\end{array}$ \\
\hline $\mathrm{PAN}+\mathrm{OH} \rightarrow \mathrm{CH} 2 \mathrm{O}+\mathrm{NO} 3$ & $4.00 \mathrm{E}-14$ \\
\hline C-3 degradation & Rate \\
\hline $\mathrm{C} 3 \mathrm{H} 6+\mathrm{OH}+\mathrm{M} \rightarrow \mathrm{PO} 2+\mathrm{M}$ & $\begin{array}{l}\mathrm{ko}=8.00 \mathrm{E}-27 *(300 / \mathrm{t}) * 3.50 \\
\mathrm{ki}=3.00 \mathrm{E}-11 \\
\mathrm{f}=0.50\end{array}$ \\
\hline $\begin{array}{l}\mathrm{C} 3 \mathrm{H} 6+\mathrm{O} 3 \rightarrow .54 * \mathrm{CH} 2 \mathrm{O}+.19 * \mathrm{HO} 2+.33 * \mathrm{OH}+.08 * \mathrm{CH} 4+.56 * \mathrm{CO} \\
+.5 * \mathrm{CH} 3 \mathrm{CHO}+.31 * \mathrm{CH} 3 \mathrm{O} 2+.25 * \mathrm{CH} 3 \mathrm{COOH}\end{array}$ & $6.50 \mathrm{E}-15^{*} \exp (-1900 . / \mathrm{t})$ \\
\hline $\mathrm{C} 3 \mathrm{H} 6+\mathrm{NO} 3 \rightarrow$ ONIT & 4.60E-13*exp( $-1156 . / \mathrm{t})$ \\
\hline $\mathrm{C} 3 \mathrm{H} 7 \mathrm{O} 2+\mathrm{NO} \rightarrow .82 * \mathrm{CH} 3 \mathrm{COCH} 3+\mathrm{NO} 2+\mathrm{HO} 2+.27 * \mathrm{CH} 3 \mathrm{CHO}$ & $4.20 \mathrm{E}-12 * \exp (180 . / \mathrm{t})$ \\
\hline $\mathrm{C} 3 \mathrm{H} 7 \mathrm{O} 2+\mathrm{HO} 2 \rightarrow \mathrm{C} 3 \mathrm{H} 7 \mathrm{OOH}+\mathrm{O} 2$ & $7.50 \mathrm{E}-13 * \exp (700 . / \mathrm{t})$ \\
\hline $\mathrm{C} 3 \mathrm{H} 7 \mathrm{O} 2+\mathrm{CH} 3 \mathrm{O} 2 \rightarrow \mathrm{CH} 2 \mathrm{O}+\mathrm{HO} 2+.82 * \mathrm{CH} 3 \mathrm{COCH} 3$ & $3.75 \mathrm{E}-13 * \exp (-40 . / \mathrm{t})$ \\
\hline $\mathrm{C} 3 \mathrm{H} 7 \mathrm{OOH}+\mathrm{OH} \rightarrow \mathrm{H} 2 \mathrm{O}+\mathrm{C} 3 \mathrm{H} 7 \mathrm{O} 2$ & $3.80 \mathrm{E}-12 * \exp (200 . / \mathrm{t})$ \\
\hline $\mathrm{C} 3 \mathrm{H} 8+\mathrm{OH} \rightarrow \mathrm{C} 3 \mathrm{H} 7 \mathrm{O} 2+\mathrm{H} 2 \mathrm{O}$ & $8.70 \mathrm{E}-12 * \exp (-615 . / \mathrm{t})$ \\
\hline $\mathrm{PO} 2+\mathrm{NO} \rightarrow \mathrm{CH} 3 \mathrm{CHO}+\mathrm{CH} 2 \mathrm{O}+\mathrm{HO} 2+\mathrm{NO} 2$ & $4.20 \mathrm{E}-12 * \exp (180 . / \mathrm{t})$ \\
\hline $\mathrm{PO} 2+\mathrm{HO} 2 \rightarrow \mathrm{POOH}+\mathrm{O} 2$ & $7.50 \mathrm{E}-13 * \exp (700 . / \mathrm{t})$ \\
\hline $\mathrm{POOH}+\mathrm{OH} \rightarrow .5^{*} \mathrm{PO} 2+.5^{*} \mathrm{OH}+.5^{*} \mathrm{HYAC}+\mathrm{H} 2 \mathrm{O}$ & $3.80 \mathrm{E}-12 * \exp (200 . / \mathrm{t})$ \\
\hline $\mathrm{CH} 3 \mathrm{COCH} 3+\mathrm{OH} \rightarrow \mathrm{RO} 2+\mathrm{H} 2 \mathrm{O}$ & $\begin{array}{l}3.82 \mathrm{E}-11 * \exp (-2000 / \mathrm{t}) \\
+.33 \mathrm{E}-13\end{array}$ \\
\hline $\mathrm{RO} 2+\mathrm{NO} \rightarrow \mathrm{CH} 3 \mathrm{CO} 3+\mathrm{CH} 2 \mathrm{O}+\mathrm{NO} 2$ & $2.90 \mathrm{E}-12 * \exp (300 . / \mathrm{t})$ \\
\hline $\mathrm{RO} 2+\mathrm{HO} 2 \rightarrow \mathrm{ROOH}+\mathrm{O} 2$ & $8.60 \mathrm{E}-13 * \exp (700 . / \mathrm{t})$ \\
\hline $\begin{array}{l}\mathrm{RO} 2+\mathrm{CH} 3 \mathrm{O} 2 \rightarrow .3 * \mathrm{CH} 3 \mathrm{CO} 3+.8 * \mathrm{CH} 2 \mathrm{O}+.3 * \mathrm{HO} 2+.2 * \mathrm{HYAC} \\
+.5 * \mathrm{CH} 3 \mathrm{COCHO}+.5 * \mathrm{CH} 3 \mathrm{OH}\end{array}$ & $7.10 \mathrm{E}-13 * \exp (500 . / \mathrm{t})$ \\
\hline
\end{tabular}


Table A2. Continued.

\begin{tabular}{|c|c|}
\hline C-3 degradation & Rate \\
\hline $\mathrm{ROOH}+\mathrm{OH} \rightarrow \mathrm{RO} 2+\mathrm{H} 2 \mathrm{O}$ & $3.80 \mathrm{E}-12 * \exp (200 . / \mathrm{t})$ \\
\hline $\mathrm{HYAC}+\mathrm{OH} \rightarrow \mathrm{CH} 3 \mathrm{COCHO}+\mathrm{HO} 2$ & $3.00 \mathrm{E}-12$ \\
\hline $\mathrm{CH} 3 \mathrm{COCHO}+\mathrm{OH} \rightarrow \mathrm{CH} 3 \mathrm{CO} 3+\mathrm{CO}+\mathrm{H} 2 \mathrm{O}$ & $8.40 \mathrm{E}-13 * \exp (830 . / \mathrm{t})$ \\
\hline $\mathrm{CH} 3 \mathrm{COCHO}+\mathrm{NO} 3 \rightarrow \mathrm{HNO} 3+\mathrm{CO}+\mathrm{CH} 3 \mathrm{CO} 3$ & $1.40 \mathrm{E}-12 * \exp (-1860 . / \mathrm{t})$ \\
\hline $\mathrm{ONIT}+\mathrm{OH} \rightarrow \mathrm{NO} 2+\mathrm{CH} 3 \mathrm{COCHO}$ & $6.80 \mathrm{E}-13$ \\
\hline \multicolumn{2}{|l|}{ C-4 degradation } \\
\hline BIGENE + OH $\rightarrow$ ENEO2 & $5.40 \mathrm{E}-11$ \\
\hline $\mathrm{ENEO} 2+\mathrm{NO} \rightarrow \mathrm{CH} 3 \mathrm{CHO}+.5 * \mathrm{CH} 2 \mathrm{O}+.5 * \mathrm{CH} 3 \mathrm{COCH} 3+\mathrm{HO} 2+\mathrm{NO} 2$ & 4.20E-12*exp( 180./t) \\
\hline $\mathrm{MVK}+\mathrm{OH} \rightarrow \mathrm{MACRO} 2$ & $4.13 \mathrm{E}-12 * \exp (452 . / \mathrm{t})$ \\
\hline $\begin{array}{l}\mathrm{MVK}+\mathrm{O} 3 \rightarrow .8 * \mathrm{CH} 2 \mathrm{O}+.95 * \mathrm{CH} 3 \mathrm{COCHO}+.08 * \mathrm{OH}+.2 * \mathrm{O} 3+.06 * \mathrm{HO} 2 \\
+.05 * \mathrm{CO}+.04 * \mathrm{CH} 3 \mathrm{CHO}\end{array}$ & 7.52E-16*exp( $-1521 . / \mathrm{t})$ \\
\hline $\mathrm{MEK}+\mathrm{OH} \rightarrow \mathrm{MEKO} 2$ & $2.30 \mathrm{E}-12 * \exp (-170 . / \mathrm{t})$ \\
\hline $\mathrm{MEKO} 2+\mathrm{NO} \rightarrow \mathrm{CH} 3 \mathrm{CO} 3+\mathrm{CH} 3 \mathrm{CHO}+\mathrm{NO} 2$ & $4.20 \mathrm{E}-12 * \exp (180 . / \mathrm{t})$ \\
\hline $\mathrm{MEKO} 2+\mathrm{HO} 2 \rightarrow \mathrm{MEKOOH}$ & $7.50 \mathrm{E}-13 * \exp (700 . / \mathrm{t})$ \\
\hline $\mathrm{MEKOOH}+\mathrm{OH} \rightarrow \mathrm{MEKO} 2$ & $3.80 \mathrm{E}-12 * \exp (200 . / \mathrm{t})$ \\
\hline $\mathrm{MACR}+\mathrm{OH} \rightarrow .5 * \mathrm{MACRO} 2+.5 * \mathrm{H} 2 \mathrm{O}+.5 * \mathrm{MCO} 3$ & $1.86 \mathrm{E}-11^{*} \exp (175 . / \mathrm{t})$ \\
\hline $\begin{array}{l}\mathrm{MACR}+\mathrm{O} 3 \rightarrow .8 * \mathrm{CH} 3 \mathrm{COCHO}+.275 * \mathrm{HO} 2+.2 * \mathrm{CO}+.2 * \mathrm{O} 3+.7 * \mathrm{CH} 2 \mathrm{O} \\
+.215 * \mathrm{OH}\end{array}$ & $4.40 \mathrm{E}-15 * \exp (-2500 . / \mathrm{t})$ \\
\hline $\begin{array}{l}\mathrm{MACRO} 2+\mathrm{NO} \rightarrow \mathrm{NO} 2+.47 * \mathrm{HO} 2+.25 * \mathrm{CH} 2 \mathrm{O}+.53 * \mathrm{GLYALD} \\
+.25 * \mathrm{CH} 3 \mathrm{COCHO}+.53 * \mathrm{CH} 3 \mathrm{CO} 3+.22 * \mathrm{HYAC}+.22 * \mathrm{CO}\end{array}$ & $2.70 \mathrm{E}-12 * \exp (360 . / \mathrm{t})$ \\
\hline $\mathrm{MACRO} 2+\mathrm{NO} \rightarrow 0.8 * \mathrm{ONITR}$ & $1.30 \mathrm{E}-13 * \exp (360 . / \mathrm{t})$ \\
\hline $\begin{array}{l}\mathrm{MACRO} 2+\mathrm{NO} 3 \rightarrow \mathrm{NO} 2+.47 * \mathrm{HO} 2+.25 * \mathrm{CH} 2 \mathrm{O}+.25 * \mathrm{CH} 3 \mathrm{COCHO} \\
+.22 * \mathrm{CO}+.53 * \text { GLYALD }+.22 * \mathrm{HYAC}+.53 * \mathrm{CH} 3 \mathrm{CO} 3\end{array}$ & $2.40 \mathrm{E}-12$ \\
\hline $\mathrm{MACRO} 2+\mathrm{HO} 2 \rightarrow \mathrm{MACROOH}$ & $8.00 \mathrm{E}-13 * \exp (700 . / \mathrm{t})$ \\
\hline $\begin{array}{l}\mathrm{MACRO} 2+\mathrm{CH} 3 \mathrm{O} 2 \rightarrow .73 * \mathrm{HO} 2+.88 * \mathrm{CH} 2 \mathrm{O}+.11 * \mathrm{CO}+.24 * \mathrm{CH} 3 \mathrm{COCHO} \\
+.26 * \mathrm{GLYALD}+.26 * \mathrm{CH} 3 \mathrm{CO} 3+.25 * \mathrm{CH} 3 \mathrm{OH}+.23 * \mathrm{HYAC}\end{array}$ & $5.00 \mathrm{E}-13 * \exp (400 . / \mathrm{t})$ \\
\hline $\begin{array}{l}\mathrm{MACRO} 2+\mathrm{CH} 3 \mathrm{CO} 3 \rightarrow .25 * \mathrm{CH} 3 \mathrm{COCHO}+\mathrm{CH} 3 \mathrm{O} 2+.22 * \mathrm{CO}+.47 * \mathrm{HO} 2 \\
+.53 * \mathrm{GLYALD}+.22 * \mathrm{HYAC}+.25 * \mathrm{CH} 2 \mathrm{O}+.53 * \mathrm{CH} 3 \mathrm{CO} 3\end{array}$ & $1.40 \mathrm{E}-11$ \\
\hline $\mathrm{MACROOH}+\mathrm{OH} \rightarrow .5 * \mathrm{MCO} 3+.2 * \mathrm{MACRO} 2+.1 * \mathrm{OH}+.2 * \mathrm{HO} 2$ & $2.30 \mathrm{E}-11 * \exp (200 . / \mathrm{t})$ \\
\hline $\mathrm{MCO} 3+\mathrm{NO} \rightarrow \mathrm{NO} 2+\mathrm{CH} 2 \mathrm{O}+\mathrm{CH} 3 \mathrm{CO} 3$ & $5.30 \mathrm{E}-12 * \exp (360 . / \mathrm{t})$ \\
\hline $\mathrm{MCO} 3+\mathrm{NO} 3 \rightarrow \mathrm{NO} 2+\mathrm{CH} 2 \mathrm{O}+\mathrm{CH} 3 \mathrm{CO} 3$ & $5.00 \mathrm{E}-12$ \\
\hline $\mathrm{MCO} 3+\mathrm{HO} 2 \rightarrow .25 * \mathrm{O} 3+.25^{*} \mathrm{CH} 3 \mathrm{COOH}+.75^{*} \mathrm{CH} 3 \mathrm{COOOH}+.75^{*} \mathrm{O} 2$ & $4.30 \mathrm{E}-13 * \exp (1040 . / \mathrm{t})$ \\
\hline $\mathrm{MCO} 3+\mathrm{CH} 3 \mathrm{O} 2 \rightarrow 2 * \mathrm{CH} 2 \mathrm{O}+\mathrm{HO} 2+\mathrm{CO} 2+\mathrm{CH} 3 \mathrm{CO} 3$ & $2.00 \mathrm{E}-12 * \exp (500 . / \mathrm{t})$ \\
\hline $\mathrm{MCO} 3+\mathrm{CH} 3 \mathrm{CO} 3 \rightarrow 2 * \mathrm{CO} 2+\mathrm{CH} 3 \mathrm{O} 2+\mathrm{CH} 2 \mathrm{O}+\mathrm{CH} 3 \mathrm{CO} 3$ & $4.60 \mathrm{E}-12 * \exp (530 . / \mathrm{t})$ \\
\hline $\mathrm{MCO} 3+\mathrm{MCO} 3 \rightarrow 2 * \mathrm{CO} 2+2 * \mathrm{CH} 2 \mathrm{O}+2 * \mathrm{CH} 3 \mathrm{CO} 3$ & $2.30 \mathrm{E}-12 * \exp (530 . / \mathrm{t})$ \\
\hline $\mathrm{MCO} 3+\mathrm{NO} 2+\mathrm{M} \rightarrow \mathrm{MPAN}+\mathrm{M}$ & $1.1 \mathrm{E}-11 * 300 . / \mathrm{t} /[\mathrm{M}]$ \\
\hline $\mathrm{MPAN}+\mathrm{M} \rightarrow \mathrm{MCO} 3+\mathrm{NO} 2+\mathrm{M}$ & $\begin{array}{l}\mathrm{k}(\mathrm{MCO} 3+\mathrm{NO} 2+\mathrm{M}) \\
* 1.111 \mathrm{E} 28 * \exp (-14000 / \mathrm{t})\end{array}$ \\
\hline $\begin{array}{l}\mathrm{MPAN}+\mathrm{OH}+\mathrm{M} \rightarrow .5 * \mathrm{HYAC}+.5 * \mathrm{NO} 3+.5 * \mathrm{CH} 2 \mathrm{O}+.5 * \mathrm{HO} 2 \\
+0.5 * \mathrm{CO} 2+\mathrm{M}\end{array}$ & $\begin{array}{l}\mathrm{ko}=8.00 \mathrm{E}-27 *(300 / \mathrm{t}) * 3.50 \\
\mathrm{ki}=3.00 \mathrm{E}-11 \\
\mathrm{f}=0.50\end{array}$ \\
\hline
\end{tabular}


Table A2. Continued.

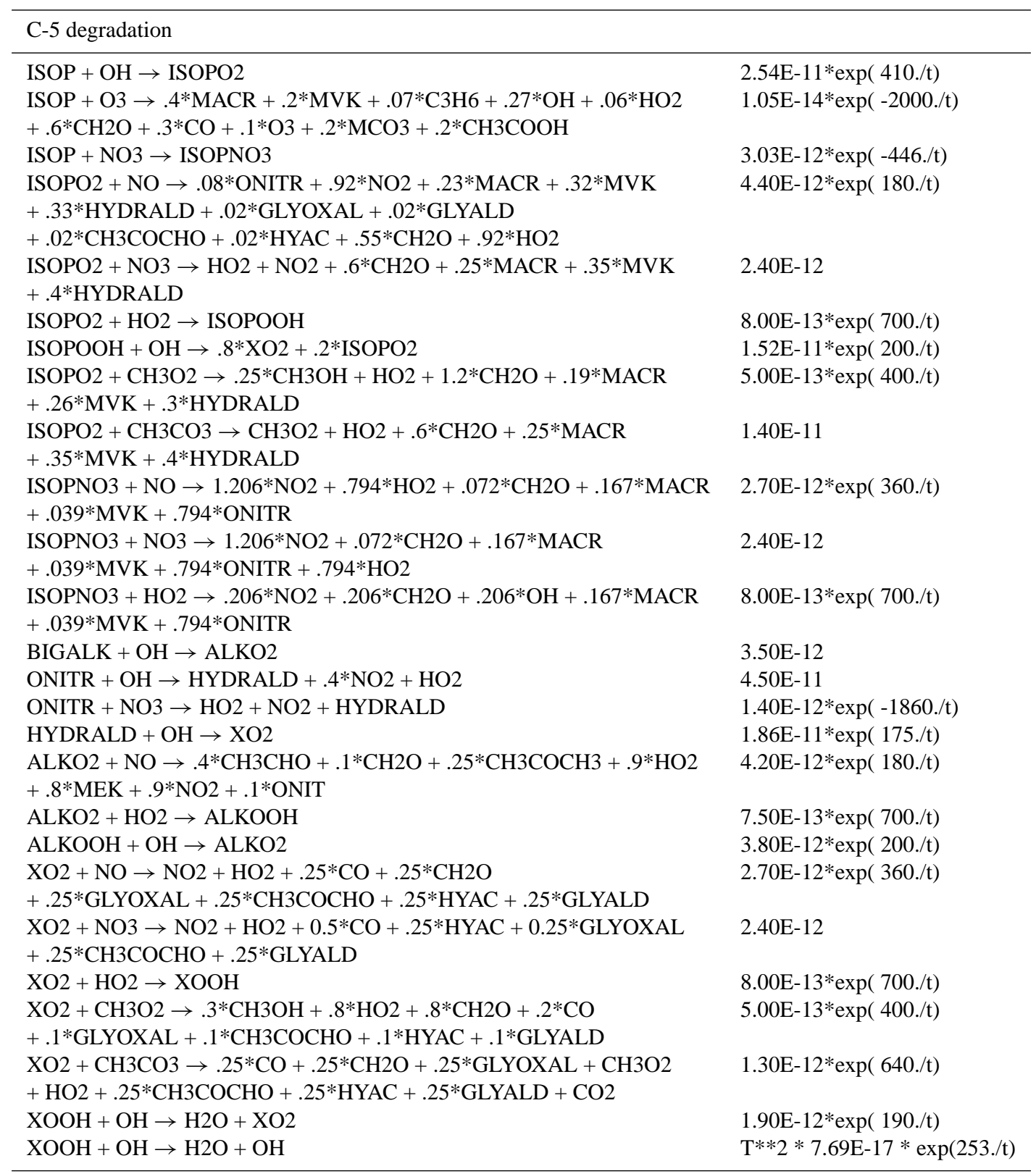


Table A2. Continued.

\begin{tabular}{|c|c|}
\hline C-7 degradation & Rate \\
\hline TOLUENE $+\mathrm{OH} \rightarrow .25 *$ CRESOL $+.25 * \mathrm{HO} 2+.7 *$ TOLO 2 & $1.70 \mathrm{E}-12 * \exp (352 . / \mathrm{t})$ \\
\hline $\begin{array}{l}\mathrm{TOLO} 2+\mathrm{NO} \rightarrow .45 * \mathrm{GLYOXAL}+.45 * \mathrm{CH} 3 \mathrm{COCHO}+.9 * \mathrm{BIGALD} \\
+.9 * \mathrm{NO} 2+.9 * \mathrm{HO} 2\end{array}$ & $4.20 \mathrm{E}-12 * \exp (180 . / \mathrm{t})$ \\
\hline $\mathrm{TOLO} 2+\mathrm{HO} 2 \rightarrow \mathrm{TOLOOH}$ & $7.50 \mathrm{E}-13 * \exp (700 . / \mathrm{t})$ \\
\hline $\mathrm{TOLOOH}+\mathrm{OH} \rightarrow \mathrm{TOLO} 2$ & $3.80 \mathrm{E}-12 * \exp (200 . / \mathrm{t})$ \\
\hline $\mathrm{CRESOL}+\mathrm{OH} \rightarrow \mathrm{XOH}$ & $3.00 \mathrm{E}-12$ \\
\hline $\mathrm{XOH}+\mathrm{NO} 2 \rightarrow .7 * \mathrm{NO} 2+.7 * \mathrm{BIGALD}+.7 * \mathrm{HO} 2$ & $1.00 \mathrm{E}-11$ \\
\hline $\mathrm{BENZENE}+\mathrm{OH} \rightarrow \mathrm{BENO} 2$ & $2.30 \mathrm{E}-12 * \exp (-193 . / \mathrm{t})$ \\
\hline $\mathrm{BENO} 2+\mathrm{HO} 2 \rightarrow \mathrm{BENOOH}$ & $1.40 \mathrm{E}-12 * \exp (700 . / \mathrm{t})$ \\
\hline $\mathrm{BENO} 2+\mathrm{NO} \rightarrow 0.9 * \mathrm{GLYOXAL}+0.9 * \mathrm{BIGALD}+0.9 * \mathrm{NO} 2+0.9 * \mathrm{HO} 2$ & $2.60 \mathrm{E}-12 * \exp (350 . / \mathrm{t})$ \\
\hline $\mathrm{XYLENE}+\mathrm{OH} \rightarrow \mathrm{XYLO} 2$ & $2.30 \mathrm{E}-11$ \\
\hline $\mathrm{XYLO} 2+\mathrm{HO} 2 \rightarrow \mathrm{XYLOOH}$ & $1.40 \mathrm{E}-12 * \exp (700 . / \mathrm{t})$ \\
\hline $\begin{array}{l}\mathrm{XYLO} 2+\mathrm{NO} \rightarrow 0.62 * \mathrm{BIGALD}+0.34 * \mathrm{GLYOXAL}+0.54 * \mathrm{CH} 3 \mathrm{COCHO} \\
+0.9 * \mathrm{NO} 2+0.9 * \mathrm{HO} 2\end{array}$ & $2.60 \mathrm{E}-12 * \exp (350 . / \mathrm{t})$ \\
\hline \multicolumn{2}{|l|}{ C-10 degradation } \\
\hline $\mathrm{C} 10 \mathrm{H} 16+\mathrm{OH} \rightarrow \mathrm{TERPO} 2$ & $1.20 \mathrm{E}-11 * \exp (444 . / \mathrm{t})$ \\
\hline $\mathrm{C} 10 \mathrm{H} 16+\mathrm{O} 3 \rightarrow .7 * \mathrm{OH}+\mathrm{MVK}+\mathrm{MACR}+\mathrm{HO} 2$ & $1.00 \mathrm{E}-15 * \exp (-732 . / \mathrm{t})$ \\
\hline $\mathrm{C} 10 \mathrm{H} 16+\mathrm{NO} 3 \rightarrow \mathrm{TERPO} 2+\mathrm{NO} 2$ & $1.20 \mathrm{E}-12 * \exp (490 . / \mathrm{t})$ \\
\hline $\mathrm{TERPO} 2+\mathrm{NO} \rightarrow .1 * \mathrm{CH} 3 \mathrm{COCH} 3+\mathrm{HO} 2+\mathrm{MVK}+\mathrm{MACR}+\mathrm{NO} 2$ & $4.20 \mathrm{E}-12 * \exp (180 . / \mathrm{t})$ \\
\hline TERPO $2+\mathrm{HO} 2 \rightarrow$ TERPOOH & $7.50 \mathrm{E}-13 * \exp (700 . / \mathrm{t})$ \\
\hline $\mathrm{TERPOOH}+\mathrm{OH} \rightarrow \mathrm{TERPO} 2$ & $3.80 \mathrm{E}-12 * \exp (200 . / \mathrm{t})$ \\
\hline \multicolumn{2}{|l|}{ Tropospheric heterogeneous reactions } \\
\hline \multicolumn{2}{|l|}{$\mathrm{N} 2 \mathrm{O} 5 \rightarrow 2 * \mathrm{HNO} 3$} \\
\hline \multicolumn{2}{|l|}{$\mathrm{NO} 3 \rightarrow \mathrm{HNO} 3$} \\
\hline \multicolumn{2}{|l|}{$\mathrm{NO} 2 \rightarrow 0.5^{*} \mathrm{OH}+0.5^{*} \mathrm{NO}+0.5^{*} \mathrm{HNO} 3$} \\
\hline $\mathrm{CB} 1 \rightarrow \mathrm{CB} 2$ & $7.10 \mathrm{E}-06$ \\
\hline \multicolumn{2}{|l|}{$\mathrm{SO} 2+\mathrm{OH} \rightarrow \mathrm{SO} 4$} \\
\hline $\mathrm{DMS}+\mathrm{OH} \rightarrow \mathrm{SO} 2$ & $9.60 \mathrm{E}-12 * \exp (-234 . / \mathrm{t})$ \\
\hline \multicolumn{2}{|l|}{$\mathrm{DMS}+\mathrm{OH} \rightarrow .5 * \mathrm{SO} 2+.5 * \mathrm{HO} 2$} \\
\hline $\mathrm{DMS}+\mathrm{NO} 3 \rightarrow \mathrm{SO} 2+\mathrm{HNO} 3$ & $1.90 \mathrm{E}-13 * \exp (520 . / \mathrm{t})$ \\
\hline $\mathrm{NH} 3+\mathrm{OH} \rightarrow \mathrm{H} 2 \mathrm{O}$ & $1.70 \mathrm{E}-12 * \exp (-710 . / \mathrm{t})$ \\
\hline $\mathrm{OC} 1 \rightarrow \mathrm{OC} 2$ & $7.10 \mathrm{E}-06$ \\
\hline \multicolumn{2}{|l|}{$\mathrm{HO} 2 \rightarrow 0.5 * \mathrm{H} 2 \mathrm{O} 2$} \\
\hline \multicolumn{2}{|l|}{ Stratospheric removal rates for BAM aerosols } \\
\hline CB1 $\rightarrow$ (No products) & $6.34 \mathrm{E}-08$ \\
\hline $\mathrm{CB} 2 \rightarrow$ (No products) & $6.34 \mathrm{E}-08$ \\
\hline $\mathrm{OC} 1 \rightarrow$ (No products) & $6.34 \mathrm{E}-08$ \\
\hline $\mathrm{OC} 2 \rightarrow$ (No products) & $6.34 \mathrm{E}-08$ \\
\hline $\mathrm{SO} 4 \rightarrow$ (No products) & $6.34 \mathrm{E}-08$ \\
\hline
\end{tabular}


Table A2. Continued.

\begin{tabular}{|c|c|}
\hline \multicolumn{2}{|c|}{ Stratospheric removal rates for BAM aerosols } \\
\hline SOAM $\rightarrow$ (No products) & $6.34 \mathrm{E}-08$ \\
\hline SOAI $\rightarrow$ (No products) & $6.34 \mathrm{E}-08$ \\
\hline $\mathrm{SOAB} \rightarrow$ (No products) & $6.34 \mathrm{E}-08$ \\
\hline SOAT $\rightarrow$ (No products) & $6.34 \mathrm{E}-08$ \\
\hline SOAX $\rightarrow$ (No products) & $6.34 \mathrm{E}-08$ \\
\hline NH4 $\rightarrow$ (No products) & $6.34 \mathrm{E}-08$ \\
\hline NH4NO3 $\rightarrow$ (No products) & $6.34 \mathrm{E}-08$ \\
\hline SSLT01 $\rightarrow$ (No products) & $6.34 \mathrm{E}-08$ \\
\hline SSLT02 $\rightarrow$ (No products) & 6.34E-08 \\
\hline SSLT03 $\rightarrow$ (No products) & $6.34 \mathrm{E}-08$ \\
\hline SSLT04 $\rightarrow$ (No products) & $6.34 \mathrm{E}-08$ \\
\hline DST01 $\rightarrow$ (No products) & $6.34 \mathrm{E}-08$ \\
\hline DST02 $\rightarrow$ (No products) & $6.34 \mathrm{E}-08$ \\
\hline DST03 $\rightarrow$ (No products) & $6.34 \mathrm{E}-08$ \\
\hline DST04 $\rightarrow$ (No products) & $6.34 \mathrm{E}-08$ \\
\hline $\mathrm{SO} 2 \mathrm{t} \rightarrow$ (No products) & $6.34 \mathrm{E}-08$ \\
\hline \multicolumn{2}{|l|}{ Sulfate aerosol reactions } \\
\hline $\mathrm{N} 2 \mathrm{O} 5 \rightarrow 2 * \mathrm{HNO} 3$ & $\mathrm{f}$ (sulfuric acid wt $\%$ ) \\
\hline $\mathrm{CLONO} 2 \rightarrow \mathrm{HOCL}+\mathrm{HNO} 3$ & $\mathrm{f}(\mathrm{T}, \mathrm{P}, \mathrm{HCl}, \mathrm{H} 2 \mathrm{O}, \mathrm{r})$ \\
\hline $\mathrm{BRONO} 2 \rightarrow \mathrm{HOBR}+\mathrm{HNO} 3$ & $\mathrm{f}(\mathrm{T}, \mathrm{P}, \mathrm{H} 2 \mathrm{O}, \mathrm{r})$ \\
\hline $\mathrm{CLONO} 2+\mathrm{HCL} \rightarrow \mathrm{CL} 2+\mathrm{HNO} 3$ & $\mathrm{f}(\mathrm{T}, \mathrm{P}, \mathrm{HCl}, \mathrm{H} 2 \mathrm{O}, \mathrm{r})$ \\
\hline $\mathrm{HOCL}+\mathrm{HCL} \rightarrow \mathrm{CL} 2+\mathrm{H} 2 \mathrm{O}$ & $\mathrm{f}(\mathrm{T}, \mathrm{P}, \mathrm{HCl}, \mathrm{HOCl}, \mathrm{H} 2 \mathrm{O}, \mathrm{r})$ \\
\hline $\mathrm{HOBR}+\mathrm{HCL} \rightarrow \mathrm{BRCL}+\mathrm{H} 2 \mathrm{O}$ & $\mathrm{f}(\mathrm{T}, \mathrm{P}, \mathrm{HCl}, \mathrm{HOBr}, \mathrm{H} 2 \mathrm{O}, \mathrm{r})$ \\
\hline \multicolumn{2}{|l|}{ Nitric acid Di-hydrate reactions } \\
\hline $\mathrm{N} 2 \mathrm{O} 5 \rightarrow 2 * \mathrm{HNO} 3$ & $\gamma=0.0004$ \\
\hline $\mathrm{CLONO} 2 \rightarrow \mathrm{HOCL}+\mathrm{HNO} 3$ & $\gamma=0.004$ \\
\hline $\mathrm{CLONO} 2+\mathrm{HCL} \rightarrow \mathrm{CL} 2+\mathrm{HNO} 3$ & $\gamma=0.2$ \\
\hline $\mathrm{HOCL}+\mathrm{HCL} \rightarrow \mathrm{CL} 2+\mathrm{H} 2 \mathrm{O}$ & $\gamma=0.1$ \\
\hline $\mathrm{BRONO} 2 \rightarrow \mathrm{HOBR}+\mathrm{HNO} 3$ & $\gamma=0.3$ \\
\hline \multicolumn{2}{|l|}{ Ice aerosol reactions } \\
\hline $\mathrm{N} 2 \mathrm{O} 5 \rightarrow 2 * \mathrm{HNO} 3$ & $\gamma=0.02$ \\
\hline $\mathrm{CLONO} 2 \rightarrow \mathrm{HOCL}+\mathrm{HNO} 3$ & $\gamma=0.3$ \\
\hline $\mathrm{BRONO} 2 \rightarrow \mathrm{HOBR}+\mathrm{HNO} 3$ & $\gamma=0.3$ \\
\hline $\mathrm{CLONO} 2+\mathrm{HCL} \rightarrow \mathrm{CL} 2+\mathrm{HNO} 3$ & $\gamma=0.3$ \\
\hline $\mathrm{HOCL}+\mathrm{HCL} \rightarrow \mathrm{CL} 2+\mathrm{H} 2 \mathrm{O}$ & $\gamma=0.2$ \\
\hline $\mathrm{HOBR}+\mathrm{HCL} \rightarrow \mathrm{BRCL}+\mathrm{H} 2 \mathrm{O}$ & $\gamma=0.3$ \\
\hline \multicolumn{2}{|l|}{ Synthetic tracer reactions } \\
\hline $\mathrm{NH}_{5} \rightarrow$ (No products) & $2.31 \mathrm{E}-06$ \\
\hline $\mathrm{NH}_{50} \rightarrow$ (No products) & 2.31E-07 \\
\hline $\mathrm{NH}_{50 W} \rightarrow$ (No products) & 2.31E-07 \\
\hline $\mathrm{ST} 80_{25} \rightarrow$ (No products) & 4.63E-07 \\
\hline $\mathrm{CO}_{25} \rightarrow$ (No products) & 4.63E-07 \\
\hline $\mathrm{CO}_{50} \rightarrow$ (No products) & 2.31E-07 \\
\hline E90 $\rightarrow$ (No products $)$ & $1.29 \mathrm{E}-07$ \\
\hline E90 ${ }_{\mathrm{NH}} \rightarrow$ (No products) & $1.29 \mathrm{E}-07$ \\
\hline $\mathrm{E} 90_{\mathrm{SH}} \rightarrow$ (No products) & $1.29 \mathrm{E}-07$ \\
\hline
\end{tabular}


Table A3. Tropospheric ozone production and loss rates calculated for explicit reaction rates, O3-Prod and O3-Loss are the sum of the specific reaction rates.

\begin{tabular}{|c|c|c|c|}
\hline Production/loss ( Tg year $^{-1}$ ) & REFC1SD & REFC1 & REFC2 \\
\hline O3-Prod & 4701.1 & 4716.5 & 4758.0 \\
\hline NO-HO2 & 3032.2 & 3017.3 & 3051.7 \\
\hline $\mathrm{CH} 3 \mathrm{O} 2-\mathrm{NO}$ & 1102.1 & 1078.6 & 1072.2 \\
\hline PO2-NO & 19.8 & 20.9 & 21.1 \\
\hline CH3CO3-NO & 159.6 & 168.8 & 172.3 \\
\hline C2H5O2-NO & 8.2 & 8.1 & 7.5 \\
\hline $0.92 *$ ISOPO2-NO & 113.0 & 131.8 & 136.1 \\
\hline MACRO2-NOa & 60.9 & 68.3 & 69.9 \\
\hline MCO3-NO & 25.6 & 28.9 & 29.8 \\
\hline $\mathrm{C} 3 \mathrm{H} 7 \mathrm{O} 2-\mathrm{NO}$ & n.a. & n.a. & n.a. \\
\hline RO2-NO & 10.6 & 11.2 & 11.6 \\
\hline XO2-NO & 53.6 & 62.4 & 64.1 \\
\hline $0.9 *$ TOLO2-NO & 2.7 & 2.8 & 3.8 \\
\hline TERPO2-NO & 15.2 & 16.7 & 16.8 \\
\hline $0.9 * \mathrm{ALKO} 2-\mathrm{NO}$ & 21.6 & 21.3 & 21.7 \\
\hline ENEO2-NO & 12.0 & 12.4 & 12.5 \\
\hline EO2-NO & 34.9 & 37.2 & 37.0 \\
\hline MEKO2-NO & 16.4 & 16.1 & 16.7 \\
\hline $0.4 *$ ONITR-OH & 6.0 & 6.8 & 7.1 \\
\hline jonitr & 1.1 & 1.2 & 1.3 \\
\hline O3-Loss & 4118.0 & 4128.9 & 4157.6 \\
\hline O1D-H2O & 2217.8 & 2295.8 & 2290.2 \\
\hline $\mathrm{OH}-\mathrm{O} 3$ & 582.2 & 537.6 & 536.7 \\
\hline $\mathrm{HO} 2-\mathrm{O} 3$ & 1203.5 & 1179.0 & 1202.4 \\
\hline C3H6-O3 & 11.9 & 11.0 & 12.0 \\
\hline $0.9 *$ ISOP-O3 & 51.3 & 51.9 & 59.4 \\
\hline $\mathrm{C} 2 \mathrm{H} 4-\mathrm{O} 3$ & 7.9 & 8.0 & 8.1 \\
\hline $0.8 * \mathrm{MVK}-\mathrm{O} 3$ & 12.9 & 13.5 & 14.8 \\
\hline $0.8 *$ MACR-O3 & 2.4 & 2.4 & 2.7 \\
\hline C10H16-O3 & 28.2 & 29.6 & 31.4 \\
\hline
\end{tabular}


Acknowledgements. We thank the HIPPO team for performing reliable aircraft observations used in this study. MERRA data used in this study have been provided by the Global Modeling and Assimilation Office (GMAO) at NASA Goddard Space Flight Center through the NASA GES DISC online archive. The CESM project is supported by the National Science Foundation and the Office of Science (BER) of the USA Department of Energy. The National Center for Atmospheric Research is funded by the National Science Foundation.

Edited by: A. Stenke

\section{References}

Beres, J. H., Garcia, R. R., Boville, B. A., and Sassi, F.: Implementation of a gravity wave source spectrum parameterization dependent on the properties of convection in the Whole Atmosphere Community Climate Model (WACCM), J. Geophys. Res.Atmos., 110, 1-13, doi:10.1029/2004JD005504, 2005.

Emmons, L. K., Walters, S., Hess, P. G., Lamarque, J.-F., Pfister, G. G., Fillmore, D., Granier, C., Guenther, A., Kinnison, D., Laepple, T., Orlando, J., Tie, X., Tyndall, G., Wiedinmyer, C., Baughcum, S. L., and Kloster, S.: Description and evaluation of the Model for Ozone and Related chemical Tracers, version 4 (MOZART-4), Geosci. Model Dev., 3, 43-67, doi:10.5194/gmd3-43-2010, 2010.

Eyring, V., Lamarque, J.-F., and Hess, P.: Overview of IGAC/SPARC Chemistry-Climate Model Initiative (CCMI) Community Simulations in Support of Upcoming Ozone and Climate Assessments, Tech. rep., SPARC Newsletter No. 40, 48-66, 2013.

Fernandez, R. P., Salawitch, R. J., Kinnison, D. E., Lamarque, J.-F., and Saiz-Lopez, A.: Bromine partitioning in the tropical tropopause layer: implications for stratospheric injection, Atmos. Chem. Phys., 14, 13391-13410, doi:10.5194/acp-1413391-2014, 2014.

Granier, C., Bessagnet, B., Bond, T., D’Angiola, A., Denier van der Gon, H., Frost, G. J., Heil, A., Kaiser, J. W., Kinne, S., Klimont, Z., Kloster, S., Lamarque, J.-F., Liousse, C., Masui, T., Meleux, F., Mieville, A., Ohara, T., Raut, J.-C., Riahi, K., Schultz, M. G., Smith, S. J., Thompson, A., van Aardenne, J., van der Werf, G. R., and van Vuuren, D. P.: Evolution of anthropogenic and biomass burning emissions of air pollutants at global and regional scales during the 1980-2010 period, Climatic Change, 109, 163-190, doi:10.1007/s10584-011-0154-1, 2011.

Guenther, A. B., Jiang, X., Heald, C. L., Sakulyanontvittaya, T., Duhl, T., Emmons, L. K., and Wang, X.: The Model of Emissions of Gases and Aerosols from Nature version 2.1 (MEGAN2.1): an extended and updated framework for modeling biogenic emissions, Geosci. Model Dev., 5, 1471-1492, doi:10.5194/gmd-51471-2012, 2012.

Heald, C. L., Henze, D. K., Horowitz, L. W., Feddema, J., Lamarque, J.-F., Guenther, A., Hess, P. G., Vitt, F., Seinfeld, J. H., Goldstein, A. H., and Fung, I.: Predicted change in global secondary organic aerosol concentrations in response to future climate, emissions, and land use change, J. Geophys. Res.-Atmos., 113, D05211, doi:10.1029/2007JD009092, 2008.
Holtslag, A. and Boville, B. A.: Local versus nonlocal boundarylayer diffusion in a global climate model, J. Climate, 6, 18251842, 1993.

Kalabokas, P. D., Cammas, J.-P., Thouret, V., Volz-Thomas, A., Boulanger, D., and Repapis, C. C.: Examination of the atmospheric conditions associated with high and low summer ozone levels in the lower troposphere over the eastern Mediterranean, Atmos. Chem. Phys., 13, 10339-10352, doi:10.5194/acp-1310339-2013, 2013.

Kinnison, D. E., Brasseur, G. P., Walters, S., Garcia, R. R., Marsch, D. A., Sassi, F., Boville, B. A., Harvey, V. L., Randall, C. E., Emmons, L., Lamarque, J. F., Hess, P., Orlando, J. J., Tie, X. X., Randel, W., Pan, L. L., Gettelman, A., Granier, C., Diehl, T., Niemaier, U., and Simmons, A. J.: Sensitivity of chemical tracers to meteorological parameters in the MOZART3 chemical transport model, J. Geophys. Res., 112, D20302, doi:10.1029/2006JD007879, 2007.

Lamarque, J.-F., Bond, T. C., Eyring, V., Granier, C., Heil, A., Klimont, Z., Lee, D., Liousse, C., Mieville, A., Owen, B., Schultz, M. G., Shindell, D., Smith, S. J., Stehfest, E., Van Aardenne, J., Cooper, O. R., Kainuma, M., Mahowald, N., McConnell, J. R., Naik, V., Riahi, K., and van Vuuren, D. P.: Historical (1850-2000) gridded anthropogenic and biomass burning emissions of reactive gases and aerosols: methodology and application, Atmos. Chem. Phys., 10, 7017-7039, doi:10.5194/acp10-7017-2010, 2010.

Lamarque, J.-F., Emmons, L. K., Hess, P. G., Kinnison, D. E., Tilmes, S., Vitt, F., Heald, C. L., Holland, E. A., Lauritzen, P. H., Neu, J., Orlando, J. J., Rasch, P. J., and Tyndall, G. K.: CAM-chem: description and evaluation of interactive atmospheric chemistry in the Community Earth System Model, Geosci. Model Dev., 5, 369-411, doi:10.5194/gmd-5-369-2012, 2012.

Li, M., Zhang, Q., Streets, D. G., He, K. B., Cheng, Y. F., Emmons, L. K., Huo, H., Kang, S. C., Lu, Z., Shao, M., Su, H., Yu, X., and Zhang, Y.: Mapping Asian anthropogenic emissions of nonmethane volatile organic compounds to multiple chemical mechanisms, Atmos. Chem. Phys., 14, 5617-5638, doi:10.5194/acp14-5617-2014, 2014.

Liu, X., Easter, R. C., Ghan, S. J., Zaveri, R., Rasch, P., Shi, X., Lamarque, J.-F., Gettelman, A., Morrison, H., Vitt, F., Conley, A., Park, S., Neale, R., Hannay, C., Ekman, A. M. L., Hess, P., Mahowald, N., Collins, W., Iacono, M. J., Bretherton, C. S., Flanner, M. G., and Mitchell, D.: Toward a minimal representation of aerosols in climate models: description and evaluation in the Community Atmosphere Model CAM5, Geosci. Model Dev., 5, 709-739, doi:10.5194/gmd-5-709-2012, 2012.

Mahowald, N. M., Yoshioka, M., Collins, W. D., Conley, A. J., Fillmore, D. W., and Coleman, D. B.: Climate response and radiative forcing from mineral aerosols during the last glacial maximum, pre-industrial, current and doubled-carbon dioxide climates, Geophys. Res. Lett., 33, 2-5, doi:10.1029/2006GL026126, 2006.

Marsh, D. R., Mills, M. J., Kinnison, D. E., Lamarque, J.-F., Calvo, N., and Polvani, L. M.: Climate Change from 1850 to 2005 Simulated in CESM1(WACCM), J. Climate, 26, 7372-7391, doi:10.1175/JCLI-D-12-00558.1, 2013.

Matthes, K., Marsh, D. R., Garcia, R. R., Kinnison, D. E., Sassi, F., and Walters, S.: Role of the QBO in modulating the influence of the 11 year solar cycle on the atmosphere us- 
ing constant forcings, J. Geophys. Res.-Atmos., 115, 1-17, doi:10.1029/2009JD013020, 2010.

McFarlanle, N. A.: The effect of orographically excited wave drag on the general circulation of the lower stratosphere and troposphere, J. Aerosol Sci., 44, 175-1800, 1987.

Murray, L. T., Mickley, L. J., Kaplan, J. O., Sofen, E. D., Pfeiffer, M., and Alexander, B.: Factors controlling variability in the oxidative capacity of the troposphere since the Last Glacial Maximum, Atmos. Chem. Phys., 14, 3589-3622, doi:10.5194/acp-143589-2014, 2014.

Naik, V., Voulgarakis, A., Fiore, A. M., Horowitz, L. W., Lamarque, J.-F., Lin, M., Prather, M. J., Young, P. J., Bergmann, D., Cameron-Smith, P. J., Cionni, I., Collins, W. J., Dalsøren, S. B., Doherty, R., Eyring, V., Faluvegi, G., Folberth, G. A., Josse, B., Lee, Y. H., MacKenzie, I. A., Nagashima, T., van Noije, T. P. C., Plummer, D. A., Righi, M., Rumbold, S. T., Skeie, R., Shindell, D. T., Stevenson, D. S., Strode, S., Sudo, K., Szopa, S., and Zeng, G.: Preindustrial to present-day changes in tropospheric hydroxyl radical and methane lifetime from the Atmospheric Chemistry and Climate Model Intercomparison Project (ACCMIP), Atmos. Chem. Phys., 13, 5277-5298, doi:10.5194/acp-13-5277-2013, 2013.

Neale, R. B., Richter, J. H., and Jochum, M.: The impact of convection on ENSO: From a delayed oscillator to a series of events, J. Climate, 21, 5904-5924, doi:10.1175/2008JCLI2244.1, 2008.

Neale, R. B., Richter, J. H., Conley, A. J., Park, S., Lauritzen, P. H., Gettelman, A., Williamson, D. L., Rasch, P. J., Vavrus, S. J., Taylor, M. A., Collins, W. D., Zhang, M., and Lin, S.-J.: Description of the NCAR Community Atmosphere Model (CAM 4.0), Tech. rep., NCAR/TN-485+STR, NCAR TECHNICAL NOTE, 2010.

Neale, R. B., Richter, J., Park, S., Lauritzen, P. H., Vavrus, S. J., Rasch, P. J., and Zhang, M.: The Mean Climate of the Community Atmosphere Model (CAM4) in Forced SST and Fully Coupled Experiments, J. Climate, 26, 5150-5168, doi:10.1175/JCLID-12-00236.1, 2013.

Neely III, R. R., Conley, A., Vitt, F., and Lamarque, J. F.: A Consistent Prescription of Stratospheric Aerosol for Both Radiation and Chemistry in the Community Earth System Model (CESM1), Geosci. Model Dev. Discuss., 8, 10711-10734, doi:10.5194/gmdd-8-10711-2015, 2015.

Neu, J. L. and Prather, M. J.: Toward a more physical representation of precipitation scavenging in global chemistry models: cloud overlap and ice physics and their impact on tropospheric ozone, Atmos. Chem. Phys., 12, 3289-3310, doi:10.5194/acp-12-32892012, 2012.

Prather, M. J., Holmes, C. D., and Hsu, J.: Reactive greenhouse gas scenarios: Systematic exploration of uncertainties and the role of atmospheric chemistry, Geophys. Res. Lett., 39, L09803, doi:10.1029/2012GL051440, 2012.

Price, C., Penner, J., and Prather, M. J.: NO$x$ from lightning: 1. Global distribution based on lightning physics, J. Geophys. Res.Atmos., 102, 5929-5941, 1997.

Price, J. D. and Vaughan, G.: The potential for stratospheretroposphere exchange in cut-off-low systems, Q. J. Roy. Meteor. Soc., 119, 343-365, 1993.

Richter, J. and Rasch, P. J.: Effects of convective momentum transport on the atmospheric circulation in the Community Atmosphere Model, Version 3, J. Climate, 21, 1487-1499, doi:10.1175/2007JCLI1789.1, 2008.
Richter, J. H., Sassi, F., and Garcia, R. R.: Toward a Physically Based Gravity Wave Source Parameterization in a General Circulation Model, J. Atmos. Sci., 67, 136-156, doi:10.1175/2009JAS3112.1, 2010.

Rienecker, M. M., Suarez, M. J., Gelaro, R., Todling, R., Bacmeister, J., Liu, E., Bosilovich, M. G., Schubert, S. D., Takacs, L., Kim, G.-K., Bloom, S., Chen, J., Collins, D., Conaty, A., and da Silva, A.: MERRA - NASA's Modern-Era Retrospective Analysis for Research and Applications, J. Climate, 24, 3624-3648, doi:10.1175/JCLI-D-11-00015.1, 2011.

Saiz-Lopez, A., Fernandez, R. P., Ordóñez, C., Kinnison, D. E., Gómez Martín, J. C., Lamarque, J.-F., and Tilmes, S.: Iodine chemistry in the troposphere and its effect on ozone, Atmos. Chem. Phys., 14, 13119-13143, doi:10.5194/acp-1413119-2014, 2014.

Sander, S. P., Friedl, R. R., Barker, J. R., Golden, D. M., Kurylo, M. J., Sciences, G. E., Wine, P. H., Abbatt, J. P. D., Burkholder, J. B., Kolb, C. E., Moortgat, G. K., Huie, R. E., and Orkin, V. L.: Chemical Kinetics and Photochemical Data for Use in Atmospheric Studies Evaluation Number 17 NASA Panel for Data Evaluation, JLP Publ., 10-6, 2011.

Saunois, M., Emmons, L., Lamarque, J.-F., Tilmes, S., Wespes, C., Thouret, V., and Schultz, M.: Impact of sampling frequency in the analysis of tropospheric ozone observations, Atmos. Chem. Phys., 12, 6757-6773, doi:10.5194/acp-12-6757-2012, 2012.

Simpson, I. J., Sulbaek Andersen, M. P., Meinardi, S., Bruhwiler, L., Blake, N. J., Helmig, D., Rowland, F. S., and Blake, D. R.: Long-term decline of global atmospheric ethane concentrations and implications for methane, Nature, 488, 490-494, doi:10.1038/nature11342, 2012.

Solomon, S., Kinnison, D., Bandoro, J., and Garcia, R.: imulation of polar ozone depletion: An update, J. Geophys. Res.-Atmos., 120, 7958-7974, doi:10.1002/2015JD023365, 2015.

Tanimoto, H., Zbinden, R. M., Thouret, V., and Nedelec, P.: Consistency of tropospheric ozone observations by different platforms and techniques in the global databases, Tellus B, 67, 27073, doi:10.3402/tellusb.v67.27073, 2015.

Taylor, K. E., Stouffer, R. J., and Meehl, G. A.: An Overview of CMIP5 and the experiment design, B. Am. Meteorol. Soc., 93, 485-498, doi:10.1175/BAMS-D-11-00094.1, 2012.

Tilmes, S., Lamarque, J.-F., Emmons, L. K., Conley, A., Schultz, M. G., Saunois, M., Thouret, V., Thompson, A. M., Oltmans, S. J., Johnson, B., and Tarasick, D.: Technical Note: Ozonesonde climatology between 1995 and 2011: description, evaluation and applications, Atmos. Chem. Phys., 12, 74757497, doi:10.5194/acp-12-7475-2012, 2012.

Tilmes, S., Lamarque, J.-F., Emmons, L. K., Kinnison, D. E., Ma, P.-L., Liu, X., Ghan, S., Bardeen, C., Arnold, S., Deeter, M., Vitt, F., Ryerson, T., Elkins, J. W., Moore, F., Spackman, J. R., and Val Martin, M.: Description and evaluation of tropospheric chemistry and aerosols in the Community Earth System Model (CESM1.2), Geosci. Model Dev., 8, 1395-1426, doi:10.5194/gmd-8-13952015, 2015.

Tsigaridis, K., Daskalakis, N., Kanakidou, M., Adams, P. J., Artaxo, P., Bahadur, R., Balkanski, Y., Bauer, S. E., Bellouin, N., Benedetti, A., Bergman, T., Berntsen, T. K., Beukes, J. P., Bian, H., Carslaw, K. S., Chin, M., Curci, G., Diehl, T., Easter, R. C., Ghan, S. J., Gong, S. L., Hodzic, A., Hoyle, C. R., Iversen, T., Jathar, S., Jimenez, J. L., Kaiser, J. W., Kirkevåg, A., Koch, 
D., Kokkola, H., Lee, Y. H., Lin, G., Liu, X., Luo, G., Ma, X., Mann, G. W., Mihalopoulos, N., Morcrette, J.-J., Müller, J.-F., Myhre, G., Myriokefalitakis, S., Ng, N. L., O’Donnell, D., Penner, J. E., Pozzoli, L., Pringle, K. J., Russell, L. M., Schulz, M., Sciare, J., Seland, Ø., Shindell, D. T., Sillman, S., Skeie, R. B., Spracklen, D., Stavrakou, T., Steenrod, S. D., Takemura, T., Tiitta, P., Tilmes, S., Tost, H., van Noije, T., van Zyl, P. G., von Salzen, K., Yu, F., Wang, Z., Wang, Z., Zaveri, R. A., Zhang, H., Zhang, K., Zhang, Q., and Zhang, X.: The AeroCom evaluation and intercomparison of organic aerosol in global models, Atmos. Chem. Phys., 14, 10845-10895, doi:10.5194/acp-1410845-2014, 2014.

Val Martin, M., Heald, C. L., and Arnold, S. R.: Coupling dry deposition to vegetation phenology in the Community Earth System Model : Implications for the simulation of surface $\mathrm{O}_{3}$, Geophys. Res. Lett., 41, 2988-2996, doi:10.1002/2014GL059651, 2014.

Wegner, T., Kinnison, D. E., Garcia, R. R., and Solomon, S.: Simulation of polar stratospheric clouds in the specified dynamics version of the whole atmosphere community climate model, J. Geophys. Res.-Atmos., 118, 4991-5002, doi:10.1002/jgrd.50415, 2013.

WMO: Executive summary: Scientific assessment of ozone depletion: 2006, Geneva, Switzerland, 2006, 2006.

WMO (World Meteorological Organization): Scientific Assessment of Ozone Depletion: 2010, Global Ozone Research and Monitoring Project-Report No. 52, 516 pp., Geneva, Switzerland, 2011.

WMO: Scientific assessment of ozone depletion: 2014, Global Ozone Research and Monitoring Project-Report No. 51, Geneva, Switzerland, 2014.

Wofsy, S. C. and the HIPPO team: HIAPER Pole-to-Pole Observations (HIPPO): fine-grained, global-scale measurements of climatically important atmospheric gases and aerosols, Philo T. R. Soc. A, 369, 2073-86, doi:10.1098/rsta.2010.0313, 2011.
Xue, X. H., Liu, H. L., and Dou, X. K.: Parameterization of the inertial gravity waves and generation of the quasibiennial oscillation, J. Geophys. Res.-Atmos., 117, 1-14, doi:10.1029/2011JD016778, 2012.

Young, P. J., Archibald, A. T., Bowman, K. W., Lamarque, J.-F., Naik, V., Stevenson, D. S., Tilmes, S., Voulgarakis, A., Wild, O., Bergmann, D., Cameron-Smith, P., Cionni, I., Collins, W. J., Dalsøren, S. B., Doherty, R. M., Eyring, V., Faluvegi, G., Horowitz, L. W., Josse, B., Lee, Y. H., MacKenzie, I. A., Nagashima, T., Plummer, D. A., Righi, M., Rumbold, S. T., Skeie, R. B., Shindell, D. T., Strode, S. A., Sudo, K., Szopa, S., and Zeng, G.: Preindustrial to end 21 st century projections of tropospheric ozone from the Atmospheric Chemistry and Climate Model Intercomparison Project (ACCMIP), Atmos. Chem. Phys., 13, 2063 2090, doi:10.5194/acp-13-2063-2013, 2013.

Zanis, P., Hadjinicolaou, P., Pozzer, A., Tyrlis, E., Dafka, S., Mihalopoulos, N., and Lelieveld, J.: Summertime free-tropospheric ozone pool over the eastern Mediterranean/Middle East, Atmos. Chem. Phys., 14, 115-132, doi:10.5194/acp-14-115-2014, 2014.

Zhang, G. J. and McFarlanle, N. A.: Sensitivity of climate simulations to the parameterization of cumulus convection in the Canadian Climate Centre General Circulation Model, Atmos.-Ocean, 33, 407-446, 1995.

Ziemke, J. R., Chandra, S., Labow, G. J., Bhartia, P. K., Froidevaux, L., and Witte, J. C.: A global climatology of tropospheric and stratospheric ozone derived from Aura OMI and MLS measurements, Atmos. Chem. Phys., 11, 9237-9251, doi:10.5194/acp11-9237-2011, 2011.

Zink, F. and Vincent, R. A.: Wavelet analysis of stratospheric gravity wave packets over Macquarie Island: 1 . Wave parameters, J Geophys. Res., 106, 10275, doi:10.1029/2000JD900847, 2001. 